\title{
AVALIAÇÃO, IN VITRO, DA AÇÃO CARIOSTÁTICA DE MATERIAIS RESTAURADORES ESTÉTICOS EM ESMALTE BOVINO, SOB CONDIÇÕES DE SEVERO DESAFIO CARIOGÊNICO
}

\section{MARIA LIGIA GERDULLO PIN}

Tese apresentada à Faculdade de Odontologia de Bauru, da Universidade de São Paulo, como parte dos requisitos para obtenção do título de Doutor em Odontologia, área de Odontopediatria.

(Edição Revisada) 


\section{AVALIAÇÃO, IN VITRO, DA AÇÃO CARIOSTÁTICA DE MATERIAIS RESTAURADORES ESTÉTICOS EM ESMALTE BOVINO, SOB CONDIÇÕES DE SEVERO DESAFIO CARIOGÊNICO}

\section{MARIA LIGIA GERDULLO PIN}

Tese apresentada à Faculdade de Odontologia de Bauru, da Universidade de São Paulo, como parte dos requisitos para obtenção do título de Doutor em Odontologia, área de Odontopediatria.

(Edição Revisada)

Orientador:

Prof. Dr. Ruy César Camargo Abdo 
Pin, Maria Ligia Gerdullo

P65a

Avaliação, in vitro, da ação cariostática de materiais restauradores estéticos em esmalte bovino, sob condições de severo desafio cariogênico. / Maria Ligia Gerdullo Pin - Bauru, 2002.

$122 \mathrm{p}$ : il.; $30 \mathrm{~cm}$.

Tese. (Doutorado) - Faculdade de Odontologia de Bauru. USP

Orientador: Prof. Dr. Ruy César Camargo Abdo

Autorizo, exclusivamente para fins acadêmicos e científicos, a reprodução total ou parcial desta tese, por processos fotocopiadores e outros meios eletrônicos.

Assinatura da autora:

Data: 


\section{MARIA LIGIA GERDULLO PIN}

30 de julho de 1971

Cerqueira César - SP

Filiação

1989-1992

1993

1993-1994

1995-1997
Nascimento

José Carlos Gerdullo

Diná Figueiredo Gerdullo

Curso de Odontologia na Faculdade de Odontologia de Bauru - Universidade de São Paulo

Curso de Aperfeiçoamento em Odontopediatria, realizado pela PROFIS Bauru, SP

Participação no Programa de Educação Continuada, realizado pela Disciplina de Odontopediatria da Faculdade de Odontologia de Bauru, USP.

Curso de Pós Graduação em Odontologia, para Mestrado, área de Odontopediatria, na Faculdade de Odontologia de Bauru, USP. 
1998-2002

1999

Associações
Curso de Pós Graduação em Odontologia, para Doutorado, área de Odontopediatria, na Faculdade de Odontologia de Bauru, USP.

Professora Adjunta da Disciplina de Odontopediatria, na Faculdade de Odontologia da Universidade Paulista UNIP, Campus Bauru.

SBPqO - Sociedade Brasileira de Pesquisa Odontológica

GRUPO - Grupo Brasileiro de Professores de Ortodontia e Odontopediatria APCD - Associação Paulista de Cirurgiões Dentistas 
Às minhas queridas filhas Alice e Lara

Fontes de amor infinito, presentes de Deus

Pelos momentos de ausência,

Compreendendo, mesmo sem nada entender

De vocês vem a força para não desistir da caminhada

E continuar...........

Ao meu marido, João

sempre ao meu lado nesta estrada pela qual a vida nos leva companheiro e amigo, sempre solícito em todos os momentos

Aos meus pais, José Carlos e Diná

Pelo exemplo de vida, amor

Pelo incentivo constante e,

Por me darem sempre condições de lutar

Dedico com amor este trabalho!

"Tudo o que fizermos agora, será aquilo que colheremos depois"

Emmanuel 


\section{Agradeço a Deus,}

que me concedeu o valioso dom da vida, presença constante em todos os momentos, mostrando-me sempre o melhor caminho a seguir....

\section{Muito Obrigada!}

"Graças à vída, que me deu tanto me dew o riso e me dew opranto...."

Violeta Parra 
Ao meu orientador Prof. Dr. Ruy César Camargo Abdo, pela atenção dispensada, pelo incentivo e confiança em mim depositada durante a realização deste trabalho, pelo exemplo profissional, e sobretudo pelo respeito aos meus ideais,

MEUS SINCEROS AGRADECIMENTOS! 
Agradecimentos especiais,

À Profa Dra Maria Aparecida de Andrade Moreira Machado, grande exemplo de competência e perseverança. Você nos faz acreditar que somos capazes de conquistar nossos ideais. Acima de tudo, uma grande amiga.

À Profa Dra Salete Moura Bonifácio da Silva, que procura fazer do ofício de ensinar, uma constante busca pelo conhecimento. Com certeza, um exemplo a ser seguido.

Muito Obrigada!

"Nenhuma história humana é escrita sem a presença de uma ou duas mãos amigas que se estendem em nossa direção" 
Agradeço ainda:

Aos docentes da Disciplina de Odontopediatria: Dr. Aymar Pavarini, Dr. Bernardo Gonzalez Vono, Dr. José Eduardo de Oliveira Lima, Dra Maria Aparecida de Andrade Moreira Machado, Dra Maria Francisca Thereza Borro Bijella, Dr. Ruy César Camargo Abdo e Dra Salete Moura Bonifácio da Silva, cujos ensinamentos mostraram-me que ser Odontopediatra vai mais além do que simplesmente "tratar de crianças".

Aos colegas do curso de doutorado em Odontopediatria, Edmer, Fabiana, Sara, Veridiana e Tereza pelos momentos compartilhados durante o curso.

Aos funcionários da Disciplina de Odontopediatria, D. Wilma, D.Lia, Estela, Lílian e Fátima, pela amizade, incentivo e atenção.

À Faculdade de Odontologia de Bauru, na pessoa de sua Diretora, Profa Dra. Maria Fidela de Lima Navarro, por toda minha formação.

Ao Prof. Dr. José Carlos Pereira, Presidente da Comissão de Pós-Graduação e Profa. Dra. Maria Aparecida de Andrade Moreira Machado, Vice-Presidente da Comissão de Pós Graduação, pelo empenho em sempre oferecer o melhor.

À Prof. Dra Maria Fidela de Lima Navarro, cujo exemplo de dedicação, seriedade e amor a profissão, me fez enveredar pelos caminhos da pesquisa e da docência. A sua orientação precisa e entusiasmada, foi o início de tudo. 
Ao prof. Dr. Alberto Carlos Botazzo Delbem, da Faculdade de Odontologia de Araçatuba - UNESP, pela atenção e presteza com que me recebeu no laboratório de Odontopediatria e partilhou seus conhecimentos. Sem dúvida, um exemplo de seriedade e dedicação à pesquisa.

À minha querida irmã Maria Diva Gerdullo Ruiz, grande amiga $e$ incentivadora, responsável também, pela correção gramatical.

Às amigas Veri, Fabiana e Sara, cujo convívio mais próximo amenizou a caminhada.

Aos amigos Ana Luísa e Eduardo, pelo incentivo e colaboração na formatação e correção deste trabalho.

Às Profas Dras Sara e Salete pela reazlização de algumas fotos.

Ao Prof. Dr. José Roberto Pereira Lauris pela análise estatística dos resultados.

Aos Departamentos de Dentística, Materiais Dentários e Bioquímica da FOB, pela cessão de suas dependências e equipamentos imprescindíveis para a realização da parte experimental deste trabalho.

Ao Prof. Dr. José Mondelli pela gentileza de nos fornecer os dentes bovinos. Ao Departamento de Bioquímica pelo fornecimento de materiais indispensáveis à realização deste trabalho.

Ao Profa Dra Marília Afonso Rabelo Buzalaf pela cordialidade e presteza com que me acolheu no Departamento de Bioquímica. 
Aos funcionários da biblioteca da FOB pela atenção e orientação constante.

Aos funcionários Nelson (Dentística), Alcides, Lourisvalda e Sandra (Materiais Dentários), Ovídio e Telma (Bioquímica), Salvador (Associação de Alunos da Pós-Graduação) pela cordialidade e atenção dispensada.

Ao Departamento de Odontologia Infantil da Faculdade de Odontologia de Araçatuba - UNESP, por permitir a utilização de equipamentos de fundamental importância para a realização deste trabalho.

À Universidade Paulista - UNIP, campus Bauru, na pessoa do Coordenador do Curso de Odontologia, Prof. Dr. José Valdes Conti, pelo estímulo e oportunidades oferecidas.

À todos aqueles que, de alguma maneira, colaboraram e tornaram possível a realização deste trabalho.

MUITO OBRIGADA! 


\section{S U MÁRIO}

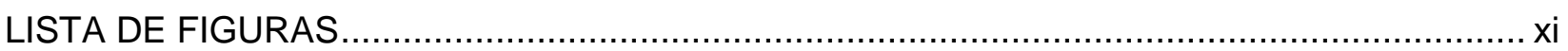

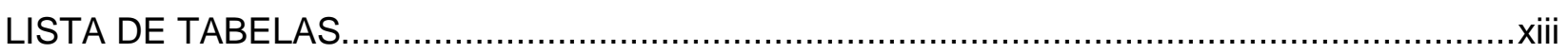

LISTA DE ABREVIATURAS E SÍMBOLOS ......................................................................

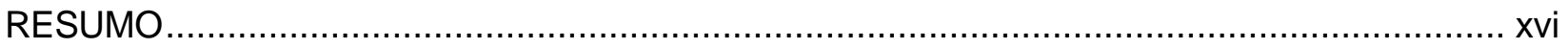

1 INTRODUÇÃO

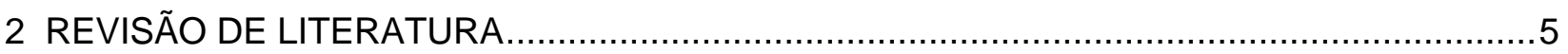

2.1 Metodologias para o estudo da perda mineral do esmalte .................................................6

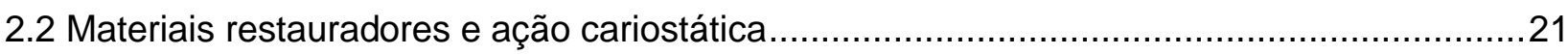

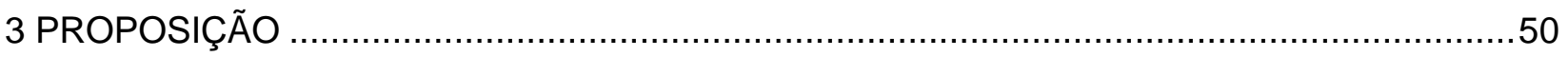

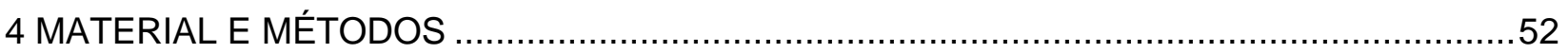

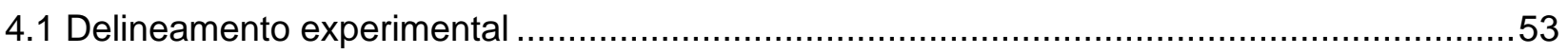

4.2 Seleção e preparo dos dentes bovinos ………………...............................................53

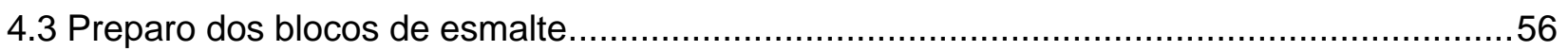

4.4 Preparo cavitário e restauração dos blocos de esmalte ....................................................58

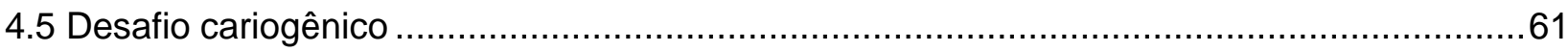

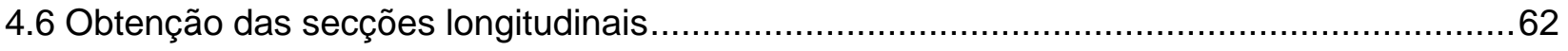

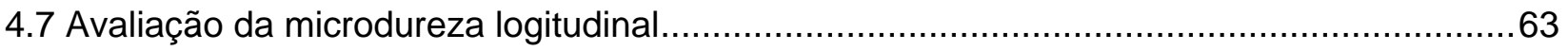

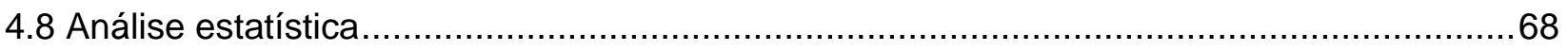

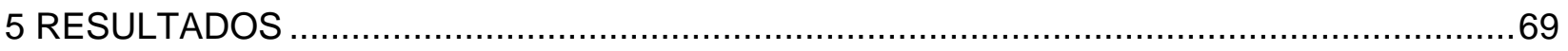

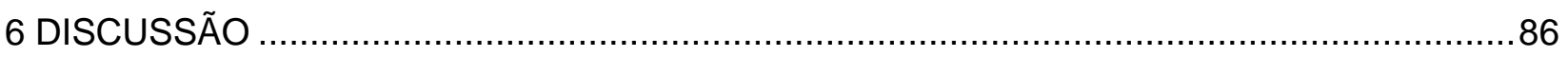

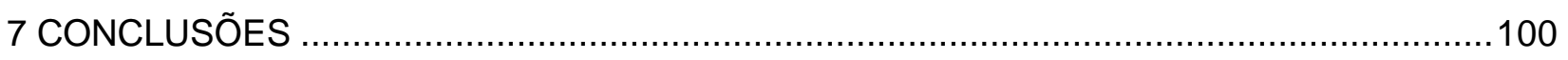

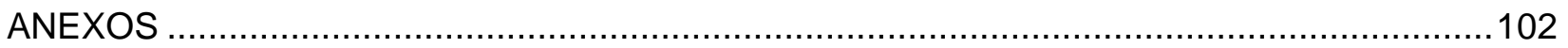

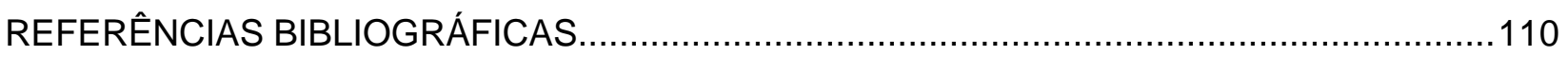

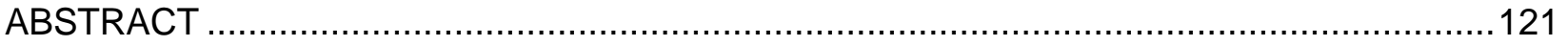




\section{LISTA DE FIGURAS}

Figura 1 -(a) Incisivo bovino antes e após o seccionamento corono-radicular. (b) Coroa fixada em disco de acrílico após secção vestíbulo-lingual. (c) Faces vestibular e lingual após separação

Figura 2 - Seccionamento na área central (A) da face vestibular da coroa para obtenção do bloco de esmalte(B)

Figura 3 - Polimento manual dos blocos de esmalte. .57

Figura 4 - (a) Ponta diamantada 1094 montada em caneta de alta rotação para realização do preparo cavitário. (b) Preparo cavitário realizado no centro do bloco de esmalte. $O$ * na cor branca, indica os blocos de esmalte descartados, recobertos por esmalte vermelho.

Figura 5 -(a) Polimento sendo realizado na politriz APL - 4 (Arotec). (b) Secções de um bloco de esmalte embutidas em disco de resina e polidas.

Figura 6 -(a) Microdurômetro SHIMADZU MICRO HARDNESS TESTER HMV- 2000. (b) Corpo de prova em posição, com lente de aumento de 50x. (c) Momento da aplicação do teste de microdureza - realização da impressão .64

Figura 7 -Pontos onde foram realizadas as impressões para avaliação da microdureza longitudinal.

Figura 8 - Indentações realizadas no esmalte hígido, não submetido ao desafio cariogênico, sem preparo cavitário. Nas seqüências de 8 marcas, a distância a partir da superfície externa do esmalte (SE) e entre elas é de $30 \mu \mathrm{m}$ 66 
Figura 9 - Esmalte hígido, não restaurado, submetido ao desafio cariogênico ./ SE= superfície externa do esmalte / $\mathrm{X}$ = área de erosão

Figura 10 - Espécime com restauração (R) / $\mathrm{SR}=$ superfície externa da restauração / $\mathrm{X}=$ área de erosão.

Figura 11 - Representação dos valores médios de microdureza Knoop para todos os tratamentos e profundidades, à distância de $50 \mu \mathrm{m}$ das paredes cavitárias / margem da restauração

Figura 12 - Representação dos valores médios de microdureza Knoop para todos os tratamentos e profundidades, à distância de $150 \mu \mathrm{m}$ das paredes cavitárias / margem da restauração.............................................................................. 71

Figura 13 - Representação dos valores médios de microdureza Knoop para todos os tratamentos e profundidades, à distância de $300 \mu \mathrm{m}$ das paredes cavitárias / margem da restauração. 


\section{LISTA DE TABELAS}

Tabela 1 - Resultado da Análise de Variância (ANOVA), comparando os fatores: tratamentos, as profundidades em relação à superfície externa do esmalte e distância das paredes cavitárias / margem da restauração. 72

Tabela 2 - Comparação entre os tratamentos nas diferentes profundidades à distância de $50 \mu \mathrm{m}$ das paredes cavitárias / margem da restauração. .73

Tabela 3 - Comparação entre os tratamentos nas diferentes profundidades à distância de $150 \mu \mathrm{m}$ das paredes cavitárias / margem da restauração. .73

Tabela 4 - Comparação entre os tratamentos nas diferentes profundidades à distância de $300 \mu \mathrm{m}$ das paredes cavitárias / margem da restauração. .74

Tabela 5 - Comparação entre as profundidades nos diferentes tratamentos à distância de $50 \mu \mathrm{m}$ das paredes cavitárias / margem da restauração. .76

Tabela 6 - Comparação entre as profundidades nos diferentes tratamentos à distância de $150 \mu \mathrm{m}$ das paredes cavitárias / margem da restauração. .77

Tabela 7 - Comparação entre as profundidades nos diferentes tratamentos à distância de $300 \mu \mathrm{m}$ das paredes cavitárias / margem da restauração. .78

Tabela 8 - Comparação entre as distâncias (50, 150 e $300 \mu \mathrm{m})$ nas diferentes profundidades no tratamento Ketac Molar $\mathrm{H}$ .80

Tabela 9 - Comparação entre as distâncias (50, 150 e $300 \mu \mathrm{m})$ nas diferentes profundidades no tratamento Ketac Molar Des. 80 
Tabela 10 - Comparação entre as distâncias (50, 150 e $300 \mu \mathrm{m})$ nas diferentes profundidades no tratamento Vitremer $\mathrm{H}$................................................80

Tabela 11 - Comparação entre as distâncias (50, 150 e $300 \mu \mathrm{m})$ nas diferentes profundidades no tratamento Vitremer Des

Tabela 12 - Comparação entre as distâncias (50, 150 e $300 \mu \mathrm{m})$ nas diferentes profundidades no tratamento Dyract AP H.

Tabela 13 - Comparação entre as distâncias (50, 150 e $300 \mu \mathrm{m})$ nas diferentes profundidades no tratamento Dyract AP Des

Tabela 14 - Comparação entre as distâncias (50, 150 e $300 \mu \mathrm{m})$ nas diferentes profundidades no tratamento $\mathrm{Z}-250 \mathrm{H}$.

Tabela 15 - Comparação entre as distâncias (50, 150 e $300 \mu \mathrm{m})$ nas diferentes profundidades no tratamento Z-250 Des.

Tabela 16 - Comparação entre as distâncias (50, 150 e $300 \mu \mathrm{m})$ nas diferentes profundidades no tratamento Controle $\mathrm{H}(\mathrm{S} / \mathrm{D})$ 82

Tabela 17 - Comparação entre as distâncias (50, 150 e $300 \mu \mathrm{m})$ nas diferentes profundidades no tratamento Controle $H(C / D)$. 83

Tabela 18 - Comparação entre as distâncias (50, 150 e $300 \mu \mathrm{m})$ nas diferentes profundidades no tratamento Controle Des (S/D). 83 


\section{LISTA DE ABREVIATURAS}

H - hígido

Des - desmineralizado

C/D - com desafio cariogênico

S/D - sem desafio cariogênico

KHN - número de dureza Knoop

" - segundos

$\boldsymbol{\mu m}$ - micrometro

mm - milímetro

$\mathbf{m m}^{2}$ - milímetro quadrado

$\mathbf{c m}^{2}$ - centímetro quadrado

$\mathrm{mL}-$ mililitro

g-grama

${ }^{\circ} \mathbf{C}$ - grau Celsius

Kgf - quilograma - força

$\%$ - porcentagem

$\mathbf{n}^{\circ}$ - número

ppm - partes por milhão

pH - potencial de hidrogênio

M - molar

$\mathbf{m} \mathbf{M}$ - milimolar

rpm - rotações por minuto

E.D.B. - esmalte dentário bovino

Dist. - distância

Prof. - profundidade

Trat. - tratamento

Fig. - Figura 


\section{RESUMO}

Considerando-se que o aparecimento de lesões de cárie ao redor de restaurações é um fato clinicamente relevante e que a utilização de materiais restauradores liberadores de flúor é importante para inibir o aparecimento destas lesões, este trabalho teve por objetivo investigar, in vitro, a ação cariostática de alguns materiais restauradores estéticos. Cavidades padronizadas foram preparadas no centro de blocos dentes bovinos hígidos ou com lesão incipiente de cárie artificial. Os espécimes foram restaurados com: um cimento de ionômero de vidro convencional (Ketac Molar); um cimento de ionômero de vidro modificado por resina (Vitremer); uma resina composta modificada por poliácidos (Dyract AP) e uma resina convencional (Z-250). Além dos espécimes restaurados, outros quatro grupos correspondentes a controles também foram avaliados. Em seguida todos os grupos, com exceção de dois dos controles, foram submetidos a ciclagens de desmineralização e remineralização durante 14 dias, simulando situação de severo desafio cariogênico. Após este procedimento, os blocos foram seccionados longitudinalmente através do centro das restaurações e a perda mineral foi avaliada por meio de testes de microdureza Knoop em secção longitudinal, aplicados em três diferentes distâncias das paredes cavitárias / margem da restauração e em oito profundidades distintas em relação à superfície externa do esmalte. A análise estatística dos resultados $(\mathrm{p}<0,05)$ mostrou diferenças significantes entre os grupos, embora nenhum dos materiais estudados tenha sido capaz de impedir completamente a instalação da lesão. O material Vitremer demonstrou a melhor ação cariostática em esmalte bovino hígido. Os materiais Ketac Molar, em esmalte hígido ou desmineralizado, assim como o Vitremer em esmalte desmineralizado, apresentaram potencial cariostástico intermediário. A resina composta Z-250 e o compômero Dyract AP não demonstraram efeitos cariostáticos. Concluí-se portanto, que os cimentos de ionômero de vidro apresentaram ação cariostática superior aos demais materiais estudados. 
1 INTRODUÇÃO 


\section{INTRODUÇÃO}

Nos últimos anos, a Odontologia tem apresentado grandes progressos em relação ao desenvolvimento de materiais e técnicas restauradoras, bem como no campo da prevenção da cárie dentária. Entretanto, é fato concreto que a necessidade de se realizar procedimentos restauradores ainda existe, principalmente aqueles relacionados à substituição ou reparo de restaurações préexistentes devido ao aparecimento de lesões de cárie secundária ${ }^{25,36,67,68}$.

Devido àdurabilidade clínica limitada de restaurações dentárias, alguns pacientes entram em um ciclo restaurador repetitivo, o qual leva à realização de restaurações mais amplas, ao enfraquecimento da estrutura dentária e ao aumento do risco da utilização de procedimentos mais invasivos ${ }^{9}$.

Muitos fatores interagem para determinar a longevidade da restauração, tais como: higiene bucal do paciente, habilidade técnica do profissional, características inerentes a cada paciente e as propriedades físico-químicas dos materiais restauradores ${ }^{87,96}$.

Com base nos conceitos atuais de que o efeito cariostático do flúor é aperfeiçoado por concentrações baixas, mas permanentes no meio bucal, a incorporação de flúor em materiais restauradores ganha interesse especial, por serem em potencial, fontes de liberação desse elemento ${ }^{17,72}$, expandindo desta maneira, o espectro da prevenção na odontologia restauradora ${ }^{56}$. Além disso, está também estabelecido que a liberação de íons flúor pelo material restaurador, por interferir no processo de desenvolvimento da cárie dentária, constitui uma propriedade importante que pode aumentar a longevidade das restaurações ${ }^{96}$.

Esta participação do flúor no mecanismo de desmineralização e remineralização de lesões de cárie incipiente de esmalte, interferindo diretamente na sua progressão $29,32,34,36,63,65,72,80,90,101,106,107$, representa o seu principal mecanismo de ação ${ }^{46}$, o que também tem estimulado o desenvolvimento e a utilização de materiais que possuam flúor na sua composição. Admite-se que parte do flúor presente nos materiais restauradores, possa ser liberado diretamente nos locais de 
risco, como as margens das restaurações, onde as cáries secundárias podem se desenvolver ${ }^{20,23,88}$, podendo ser considerado um método adicional na prevenção da cárie dentária.

As propriedades cariostáticas dos materiais restauradores podem ser elucidadas pela utilização do cimento de silicato como material restaurador estético $^{78,96}$ durante muitos anos, uma vez que dentes restaurados com este material apresentavam uma diminuição na incidência e na severidade das cáries secundárias $^{43,45,78,96}$.

O cimento de ionômero de vidro, descrito inicialmente por WILSON;KENT ${ }^{109}$ no início da década de 70 , devido às suas propriedades de adesão à estrutura dentária e às altas taxas de liberação de flúor ${ }^{15,20,27,37,38,39,49,72}$ é colocado como um material de escolha quando o selamento cavitário e a prevenção da cárie secundária são desejáveis ${ }^{16}$; necessidades estas, freqüentemente observadas na atividade clínica diária, principalmente dentro da prática da Odontopediatria, naqueles pacientes em alta atividade de cárie. Isto deve-se ao fato de que a liberação de flúor através dos cimentos de ionômero de vidro se mantém em um nível capaz de proporcionar efeito cariostático ${ }^{39,49}$.

Muito embora apresente outras propriedades importantes, como biocompatibilidade e coeficiente de expansão térmica semelhante ao da estrutura dentária, o cimento de ionômero de vidro é considerado um material crítico ${ }^{71,72}$, sendo que o seu uso efetivo depende do controle de suas limitações e da correta manipulação e esmero técnico do profissional ${ }^{11,72}$. Por isso, não tem sido tão amplamente utilizado quanto as resinas compostas ${ }^{87}$. Dentre os motivos para a grande aceitação das resinas compostas como material restaurador, destaca-se a estética altamente satisfatória ${ }^{87}$ e a aparente facilidade de manipulação.

O grande inconveniente das resinas compostas, entretanto é o surgimento de lesões de cárie secundária no esmalte adjacente à restauração, fenômeno este observado com menor freqüência em dentes restaurados com cimento de silicato ou de ionômero de vidro ${ }^{68}$. 
$\mathrm{Na}$ tentativa de se chegar a um material ideal, que associe as boas propriedades das resinas compostas às dos cimentos de ionômero de vidro, minimizando suas desvantagens, novos materiais têm sido desenvolvidos.

Os cimentos de ionômero de vidro modificados por resina, originados da incorporação de componentes resinosos ao cimento de ionômero de vidro convencional, foram introduzidos no mercado na década de 80 , apresentando características de endurecimento melhoradas, alta resistência inicial, diminuição dos fenômenos de sinérise e embebição, maior resistência total e melhor estética inicial $^{59,72,100}$. Além disso, por serem foto-ativados, tornaram-se menos sensíveis à técnica ${ }^{11}$ e estudos in vitro têm mostrado que esses materiais liberam quantidades de íons flúor semelhante aos cimentos de ionômero de vidro

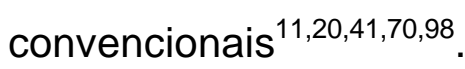

Paralelamente ao surgimento dos ionômeros modificados por resina, outra classe de materiais que possuem flúor em sua composição tem sido comercializada. Estes materiais foram denominados de resinas compostas modificadas por poliácidos ou compômeros e a eles tentou-se associar as boas propriedades mecânicas da resina composta à liberação de íons flúor do cimento de ionômero de vidro. Isto tem despertado grande interesse dos profissionais, uma vez que poderiam se aproximar de materiais restauradores ideais ${ }^{4}$. Entretanto, foi demonstrado que não apresentam a típica reação ácido-base dos cimentos de ionômero vidro convencionais e nem os mesmos graus de adesão e liberação de flúor dos verdadeiros ionômeros ${ }^{11,69}$.

Portanto, partindo-se do princípio de que a utilização de materiais restauradores liberadores de flúor é importante para inibir o aparecimento de lesões de cárie secundária, principalmente em pacientes de alto risco ${ }^{24,88}$ e/ou com alta atividade de cárie, torna-se essencial o conhecimento do comportamento destes materiais restauradores em situações de grande desafio cariogênico. Considerandose a grande variedade comercial destes diferentes materiais restauradores, que possuem flúor em sua composição, e a incontestável hegemonia das resinas compostas convencionais entre os clínicos, faz-se pertinente uma avaliação comparativa da ação cariostática destes materiais. 


\section{REVISÃO DE LITERATURA}

Devido a complexidade do assunto estudado e visando o melhor entendimento deste capítulo, o mesmo foi dividido em dois diferentes tópicos, a saber:

2.1 Metodologias para o estudo da perda mineral do esmalte, e 2.2 Materiais restauradores e ação cariostática.

\subsection{Metodologias para o estudo da perda mineral do esmalte}

Desde o início do século passado, os pesquisadores têm se interessado em estudar o desenvolvimento de lesões de cárie e suas principais características. Os primeiros estudos foram baseados principalmente no fato de que, clinicamente, o amolecimento do esmalte seria o principal critério utilizado para a identificação de lesões cariosas ${ }^{73}$.

Em 1912, HEAD ${ }^{51}$ observou que uma mancha branca por descalcificação em esmalte, produzida artificialmente, praticamente desapareceu após a imersão do esmalte em saliva. Para demonstrar que o esmalte amolecido podia ser reendurecido, desenvolveu um microdinamômetro, que consistia em um aparelho que produzia uma indentação de tamanho constante, cuja profundidade era medida quando uma pressão conhecida era aplicada.

Ainda no ano de 1912, PICKERILL ${ }^{79}$ desenvolveu um esclerômetro para medir a dureza dos dentes, fundamentando-se no princípio de resistência ao risco. O aparelho possuía um peso e uma ponta de diamante, sob a qual o dente era movimentado com pressão constante até que se observasse um risco visível macroscopicamente após aplicação de grafite sobre ele.

Baseando-se no mesmo princípio utilizado por PICKERILL ${ }^{79}$, outros pesquisadores utilizaram outros métodos para estudar e avaliar a dureza dos dentes. PROELL; SCHUBERT ${ }^{81}$ em 1928, através de um microscópio, mediam o comprimento da ranhura produzida por uma extremidade cortante, sob carga constante, ou preservavam o tamanho da marca, variando a carga aplicada. 
HODGE; MCKAY ${ }^{55}$, em 1933, com o objetivo de determinar em diferentes áreas do dente a dureza do esmalte e dentina, utilizaram um microcateter cúbico de diamante com carga constante, sendo que o risco obtido era quantificado. A dureza era calculada através da razão entre a área de impressão e a força aplicada. Esta proporção foi denominada de microdureza. Entretanto, apesar de considerarem os dados obtidos satisfatórios com relação à precisão, os autores afirmaram que os valores deveriam ser considerados apenas para efeito de comparação e não tidos como absolutos.

Com o intuito de avaliar os diversos aparelhos no estudo da dureza de tecidos dentais, HODGE ${ }^{54}$, em 1936, utilizou os seguintes aparelhos: esclerômetro, microcateter, pêndulo de Hebert, aparelho de Monotron (fazia a medição da carga necessária para que se obtivesse, através de uma esfera ou cone de diamante, uma impressão de tamanho constante) e equipamentos Brinell e Rockwell utilizados para medição da dureza em metais (baseados na medida do diâmetro da impressão feita por uma esfera sob carga conhecida). O autor observou ampla variação nas medidas de uma mesma estrutura quando da utilização dos vários aparelhos. Alguns instrumentos provocavam distorção destrutiva do corpo de prova e, por este motivo, foram considerados impróprios para medição de corpos friáveis.

Considerando-se até a década de trinta, dos testes utilizados para a avaliação da microdureza, através da resistência à penetração, nenhum deles era adequado para aplicação em estrutura dentária. Porém, KNOOP; PETERS; EMERSON, ${ }^{60}$ desenvolveram em 1939 algumas modificações nestes testes. Os autores idealizaram um penetrador de diamante em formato piramidal montado em um suporte metálico, sobre o qual se colocavam cargas de 1 a $500 \mathrm{~g}$. As impressões criadas pelo penetrador eram muito pequenas, mas bem definidas, com o formato de um losango com a diagonal maior medindo 7 vezes o comprimento da diagonal menor e 30 vezes a profundidade da impressão, permitindo o cálculo da área. As medidas obtidas eram expressas em dureza Knoop (KHN). Através da utilização do penetrador tipo Knoop, a maior parte da memória elástica do material avaliado tende a deformar a impressão transversalmente e não no seu longo eixo, proporcionando assim o estudo da microdureza em materiais frágeis como a estrutura dentária. 
Somente em 1942, surgiu na literatura o primeiro relato de um aparelho para avaliação de microdureza com penetrador tipo Knoop em Odontologia. Tal feito foi realizado por SWEENEY ${ }^{95}$ que mediu a dureza de materiais como ligas de ouro, cimentos, estrutura dentária, resinas e esboçou a aplicação deste instrumento em pesquisa odontológica.

SOUDER; SCHOONOVER ${ }^{92}$, em 1943 empregaram a microdureza Knoop para avaliar o efeito de dentifrícios, soluções contendo açúcar, flúor e ácidos na dissolução da superfície e amolecimento de esmalte e dentina. Os autores mediram também a dureza de manchas brancas e obtiveram valores de $250 \mathrm{KHN}$ para a região da lesão e $350 \mathrm{KHN}$ para o esmalte sadio adjacente. Enfatizaram também que a metodologia empregada neste trabalho permitiu a deteç̧ão de alterações na estrutura dentária de maneira rápida e sensível, quando comparada a outros métodos existentes na época para o estudo de cáries experimentais.

A microdureza Knoop também foi utilizada por PHILLIPS; SWARTZ ${ }^{77}$, em 1948, no estudo do efeito de aplicações tópicas de flúor em superfícies hígidas e desgastas de esmalte humano. Os autores chamaram a atenção para a efetividade do penetrador tipo Knoop em estudos com estruturas dentarias, pelo fato de permitir a utilização de cargas menores em superfícies pequenas e em áreas friáveis, produzindo indentações nítidas e bem definidas e minimizando a variável humana, uma vez que a aplicação e remoção da carga são controladas eletronicamente. Como resultado do estudo, relataram que houve um aumento na dureza da ordem de $5,1 \%$ após 5 minutos de imersão em fluoreto de sódio acidulado e 7,1\% quando da imersão em fluoreto estanhoso.

As primeiras lesões in vitro que se assemelhavam a lesões incipientes de cárie em esmalte foram produzidas em 1955, por HALS; MÖRCH; SAND ${ }^{44}$. Os autores expuseram áreas de esmalte de pré -molares recém irrompidos e extraídos, à ação de soluções de tampão lactato $\mathrm{com} \mathrm{pH}$ variando de 3,5 a 5,7 por períodos de 15 minutos, durante 10 dias. Como resultado, obtiveram lesões que apresentavam a superfície externa altamente mineralizada ,sob ela uma área de desmineralização e então, o esmalte normal. 
Em 1957, CALDWELL et $\mathrm{al}^{13}$. avaliaram a microdureza do esmalte humano íntegro utilizando o penetrador tipo Knoop e carga de $500 \mathrm{~g}$. Os dentes estudados apresentaram dureza média de $380 \mathrm{KHN}$, mas encontraram variações extremas entre 250 a $500 \mathrm{KHN}$ e mesmo grandes variações dentro de uma única superfície. Atribuíram tais variações à curvatura da superfície do esmalte íntegro e sugeriram que seriam menores em superfícies planas.

Com o objetivo de avaliar a microdureza do esmalte e dentina em cortes transversais, CRAIG; PEYTON ${ }^{18}$, em 1958, utilizaram o penetrômetro Knoop, aplicando carga constante de $50 \mathrm{~g}$ durante $15 \mathrm{~s}$. Segundo os autores, este procedimento resultou em indentações bem definidas com o mínimo de fraturas em torno das extremidades. A média de dureza Knoop foi de $343 \mathrm{KHN}$, variando de 272 a $440 \mathrm{KHN}$. Encontraram diferenças acentuadas em diferentes cortes de um mesmo dente e de um local para outro em um mesmo corte. Ao contrário do que se podia imaginar, as menores variações ocorreram entre as médias de microdureza de dentes diferentes e não entre as médias de vários cortes de um mesmo dente.

NEWBRUN; TIMBERLAKE; PIGMAN ${ }^{74}$, em 1959, estudaram o grau de amolecimento do esmalte após exposição a um tampão lactato com pH 5,0, utilizando os testes de microdureza superficial. Para os testes foram utilizados dentes humanos íntegros e polidos e dentes bovinos íntegros. A microdureza inicial e após a imersão no tampão por um período de até dez horas foi avaliada através de 10 impressões feitas com um penetrador tipo Knoop, sob carga de $500 \mathrm{~g}$ por 10 segundos. Observaram que a microdureza dos dentes humanos e bovinos foi, em média, 367 e $356 \mathrm{KHN}$ e que o grau de amolecimento do esmalte foi ligeiramente maior para os dentes bovinos do que para os humanos. Além disso, os dentes polidos mostraram um menor desvio-padrão entre as leituras individuais, mas a queda na dureza foi mais rápida do que para as superfícies intactas. No que diz respeito à correlação da microdureza inicial com a resistência ao amolecimento, os autores concluíram que a taxa de amolecimento era independente da dureza inicial.

Revendo a literatura a respeito dos métodos existentes para determinação da dureza do esmalte e dentina, NEWBRUN; PIGMAN ${ }^{73}$, em 1960, enfatizaram as vantagens do penetrador Knoop e concluíram que a microdureza é 
um método sensível e confiável para avaliar a progressão de lesões de cáries produzidas natural ou artificialmente.

KOULOURIDES; FEAGIN; PIGMAN ${ }^{63}$, em 1965, estudaram a capacidade de remineralização da saliva humana e artificial, utilizando dentes humanos preparados por desgaste e expostos àsolução de tampão acetato com $\mathrm{pH}$ 5,5 durante 4 e 6 horas. A princípio houve amolecimento do esmalte superficial e a microdureza ficou em torno de 60 a $150 \mathrm{KHN}$. A saliva natural por si só, mostrou capacidade de remineralização, a qual foi aumentada acentuadamente pela adição de $1 \mathrm{mM}$ de flúor. A adição de flúor na solução de saliva artificial contendo cálcio também melhorou o potencial remineralizante da solução.

Em 1966, BERGMAN; LIND ${ }^{7}$ utilizaram a microrradiografia na tentativa de quantificar o conteúdo mineral em lesões cariosas naturais, incipientes em esmalte proximal de pré-molares. Os autores observaram que abaixo das camadas superficiais que apresentavam em média $40 \mu \mathrm{m}$ de espessura e $82,7 \%$ de mineral em volume, existiam lesões de até $600 \mu \mathrm{m}$ de profundidade. Mesmo com as muitas variações encontradas, houve correlação entre a profundidade da lesão cariosa e 0 grau de perda mineral. Os autores creditaram as variações ao fato de que existem diversos fatores determinantes para a evolução da cárie dentária, tais como: estrutura e composição química do esmalte, idade da lesão, propriedades da placa e saliva, ingestão de carboidratos e presença de flúor.

Os fenômenos de desmineralização e remineralização do esmalte foram estudados em relação às alterações na microdureza superficial, em 1969, por FEAGIN; KOULOURIDES; PIGMAN ${ }^{30}$. Inicialmente, foram realizadas 5 indentações e após o amolecimento e/ou endurecimento do esmalte, outras 5 , a uma distância de $60 \mu \mathrm{m}$ das primeiras. Superfícies planas de esmalte humano e bovino foram expostas a tampão acetato de potássio com pH 5,5 por 4 a 5 horas, quando uma diminuição da dureza entre 100 e $120 \mathrm{KNH}$ pôde ser observada. Os autores observaram que a diminuição da microdureza Knoop foi linearmente proporcional à perda de cálcio e fostato ocorrida durante a desmineralização. Após a remineralização, realizada em solução remineralizante durante 1 a 6 horas, houve um aumento de dureza correspondente linearmente àaquisição de cálcio e fosfato 
pelo esmalte, demonstrando que as medidas de dureza podem ser utilizadas como indicadoras do seu índice de mineralização.

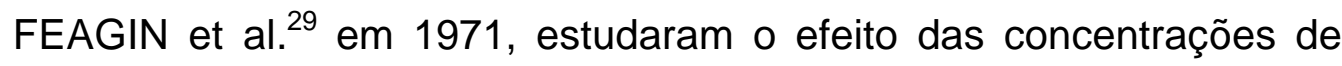
íons cálcio, fosfato, flúor e hidrogênio na remineralização de superfícies de esmalte humano e bovino parcialmente desmineralizadas. As superfícies de esmalte foram planificadas e submetidas à desmineralização em solução de ácido acético tamponado, com pH 5,5. Permaneceram na solução por 5 horas, quando se conseguiu uma diminuição na dureza de aproximadamente $100 \mathrm{KHN}$. Os autores concluíram que o aumento da concentração de íons cálcio, fosfato e hidroxila, e a adição de $1 \mathrm{ppm}$ de flúor às soluções remineralizantes aumentou o grau de remineralização do esmalte. Não encontraram diferenças entre o esmalte mineralizado naturalmente e o esmalte remineralizado na ausência de flúor Entretanto, as superfícies de esmalte remineralizadas nas soluções contendo 1 ppm de flúor foram mais resistentes a uma segunda desmineralização, além de apresentarem maior remineralização do que o esmalte mineralizado naturalmente.

A acurácia e reprodutibilidade das medidas de microdureza foram investigadas por PURDELL-LEWIS; GROENEVELD; ARENDS ${ }^{82}$, em 1971. Utilizaram esmalte hígido e desmineralizado como materiais de teste. Manchas brancas foram produzidas artificialmente em pré-molares extraídos, através da desmineralização em solução de ácido lático $0,1 \mathrm{M} \mathrm{e} \mathrm{1,6 \%} \mathrm{de} \mathrm{hidroxietil} \mathrm{celulose} \mathrm{em}$ $\mathrm{pH} \mathrm{4,0}$ por 96 horas. A microdureza foi avaliada em cortes longitudinais, com penetrador Knoop e carga de 15 gramas. As indentações foram realizadas com seu longo eixo paralelo à superfície externa do esmalte. $O$ erro do operador foi menor que $5 \%$, tanto para medidas em bloco de aço, quanto em esmalte, embora as indentações em esmalte fossem mais difíceis de serem lidas. Os resultados mostraram que os valores de dureza à mesma distância da superfície, mas em diferentes áreas da mesma lesão foram similares e que os valores entre as lesões também foram muito semelhantes. Os autores encontraram variação na microdureza de até $47 \mathrm{KHN}$ entre dois dentes, mas houve diferença de $45 \mathrm{KHN}$ em áreas de um mesmo dente. 
ARENDS; SCHUTHOF; JONGEBLOED ${ }^{5}$, em 1979, avaliaram a utilização do teste de microdureza superficial no estudo de lesões de cárie. Sessenta dentes bovinos e 50 dentes humanos, desgastados e polidos, foram submetidos aos testes de microdureza Knoop após a formação de lesões de cáries artificiais. Foram utilizadas cargas de 25, 50, 100, 200 e 500 g por 10 segundos. A dureza Knoop do esmalte humano foi de $317 \pm 30$. As diferenças entre esmalte humano e bovino foram muito pequenas, sendo que o esmalte bovino se mostrou ligeiramente mais mole. Segundo este estudo, quando o comprimento da indentação é medido em função da raiz quadrada da carga, encontra-se uma relação linear entre os esmaltes humano e bovino hígidos, assim como para o esmalte desmineralizado. Observaram que a camada superficial da lesão e o esmalte sadio subjacente não influenciaram consideravelmente as indentações. Desta forma, os autores mostraram que as medidas das indentações refletem o grau de descalcificação da lesão, apesar da camada superficial estar presente.

FEATHERSTONE;MELLBERG ${ }^{31}$, em 1981, procuraram estabelecer as diferenças entre os índices de progressão de lesões artificiais de cárie em esmalte bovino, ovino e humano. Lesões cariosas foram produzidas pelos sistemas ácido lático/ gelatina e ácido lático/disfosfonato, em diferentes períodos de tempo, em esmalte humano decíduo e permanente, esmalte bovino decíduo e permanente (desgastado ou não) e esmalte ovino permanente. As lesões conseguidas foram quantificadas através do método da incorporação de corantes. Os autores observaram que as lesões progrediram mais rapidamente no esmalte decíduo do que no esmalte permanente, tanto para o dente humano quanto para o bovino. Nos substratos, bovino permanente íntegro e desgastado e ovino permanente, as lesões foram produzidas 3 vezes mais rápido do que no esmalte humano permanente. Constataram ainda, que o grau de progressão da lesão manteve relação linear dependente da raiz quadrada do tempo, para todos os substratos estudados.

A microdureza Knoop em secções longitudinais foi utilizada por FEATHERSTONE et al. ${ }^{32}$, em 1982, para avaliar a capacidade remineralizante de soluções e dentifrícios fluoretados sobre lesões de cáries subsuperficiais em esmalte humano. Os fragmentos de esmalte foram imersos durante 7 dias em tampão 
lactato, $\mathrm{pH} 4,5$, para a produção das lesões subsuperficiais, e em seguida foram submetidos a diferentes procedimentos in vitro e in vivo. Os resultados mostraram que houve um reendurecimento significante no corpo da lesão nos grupos tratados com solução e um reendurecimento em menor profundidade, mas com dureza superficial aumentada, nos grupos tratados com dentifrício ou apenas saliva. Os autores concluíram que soluções contendo fluoreto de sódio mostraram um valor potencial na prevenção ou reversão de cáries incipientes.

Também em 1982, SILVERSTONE ${ }^{90}$ estudou qualitativa e quantitativamente o efeito do flúor na remineralização de cáries naturais e artificiais de esmalte, sendo que estas últimas foram obtidas através da exposição à gelatina acidificada. As lesões cariosas foram seccionadas longitudinalmente e examinadas em um microscópio de luz polarizada. Os estudos quantitativos foram realizados em lesões selecionadas de cada categoria de tratamento, através de um compensador Ehringhaus acoplado ao microscópio. Segundo o autor, este trabalho mostrou conclusivamente que pequenas lesões superficiais intactas em esmalte humano são passíveis de remineralização in vitro. Quando a saliva humana foi utilizada como o meio de remineralização, pequenas reduções no tamanho da lesão restritas à superfície foram observadas. Além disso, observou que a adição de 0,05mM de flúor às soluções calcificantes aumentou a remineralização. O autor ainda afirma que a remineralização ocorre naturalmente durante a formação da lesão cariosa.

FEATHERSTONE et al. ${ }^{33}$, em 1983, estabeleceram uma comparação direta entre a microrradiografia quantitativa e perfis de microdureza em cáries artificiais de esmalte humano. As lesões cariosas foram produzidas após a imersão das coroas dentais, por períodos de 3 ou 14 dias, em diferentes soluções, com pH 4,5 ou 5,0 . Em seguida, os espécimes foram seccionados longitudinalmente, através do centro das lesões e cada metade foi utilizada para uma das técnicas. Os autores observaram uma relação linear entre o volume porcentual de mineral, determinado pela microrradiografia, e a raiz quadrada do número de dureza Knoop, obtido nos testes de microdureza, no intervalo de $40-90 \%$ de mineral em volume. Puderam concluir, através deste estudo, que qualquer uma das técnicas pode ser usada para 
determinar o perfil mineral em lesões de cáries resultantes de desmineralização e, presumivelmente, remineralização.

Ainda no ano de 1983, KOULOURIDES; HOUSCH${ }^{64}$, em um "Workshop" sobre desmineralização e remineralização do esmalte, apontaram a microdureza como um dos principais testes utilizados para a avaliação do grau de desmineralização e remineralização do esmalte. De acordo com os autores, mesmo o esmalte não sendo homogêneo, principalmente quando desmineralizado e remineralizado, os testes de microdureza são extremamente sensíveis às alterações na sua densidade mineral. Os autores citam como principal vantagem deste método, o fato de ele não ser destrutivo, podendo avaliar as alterações que vão ocorrendo no mesmo espécime no decorrer do experimento. Dentre as desvantagens, citam a necessidade de uma superfície plana para a aplicação dos testes, o que requer o desgaste da camada superficial de esmalte.

Já no ano de 1986, FEATHERSTONE et al. ${ }^{34}$ basearam-se em resultados de experimentos in vivo para desenvolver um modelo de ciclagem de desmineralização e remineralização in vitro que pudesse reproduzir estes resultados. Além disso, foi também objetivo dos autores utilizar este modelo in vitro para estudar os efeitos das baixas concentrações de flúor no aumento da remineralização. Pacientes com extrações indicadas ortodonticamente foram submetidos a um mês de tratamento preventivo com dentifrício fluoretado (1000 ppm de $\mathrm{NaF}$ ), associado a bochechos de solução de fluoreto de sódio a 0,05\% e/ou a aplicações tópicas de flúor fosfato acidulado. Todos os pacientes tiveram "brackets" ortodônticos colados na superfície vestibular dos dentes teste. Após o período de tratamento, os dentes foram extraídos, seccionados longitudinalmente e avaliados quanto ao grau de desmineralização através dos testes de microdureza. Os resultados mostraram que com o uso somente do dentifrício fluoretado, ocorreu perda mineral de apenas 5 a $15 \%$ em volume. Quando o dentifrício estava associado aos outros tratamentos, ocorreu uma completa inibição da desmineralização ou completa remineralização. Estes resultados foram reproduzidos em um modelo de ciclagens de desmineralização e remineralização in vitro, durante 14 dias, incluindo tratamentos diários com produtos contendo flúor durante 5 minutos. A adição de flúor à saliva 
artificial aumentou significativamente a remineralização, sendo o efeito dependente da concentração de flúor. Esses estudos confirmam a importância da presença do flúor continuamente em concentrações relativamente baixas para a diminuição de cáries, mesmos em condições de altos desafios cariogênicos.

Com o intuito de avaliar a capacidade de remineralização in vitro de dentifrícios fluoretados sobre o esmalte desmineralizado, utilizando o modelo de ciclagem de pH, WHITE ${ }^{105}$, em 1987, também fez uma comparação entre a microdureza superficial e a microrradiografia no estudo da remineralização do esmalte. O autor chama atenção para o fato de a microdureza superficial ser um método atrativo para a medida da reatividade do esmalte, por ser um procedimento simples e não invasivo. Além disso, observou que o conteúdo mineral da superfície do esmalte tem relação linear com a diagonal da indentação ou com sua penetração. No entanto, essa relação se restringe às lesões cariosas pouco profundas (menos de $50 \mu \mathrm{m})$.O autor ainda sugere que em lesões subsuperficiais profundas, o teste de microdureza superficial deve se substituído pela microdureza longitudinal ou microrradiografia.

Ainda em 1987, WHITE; FEATHERSTONE ${ }^{106}$, utilizaram a microdureza Knoop em secções longitudinais para determinar o efeito de um dentifrício com fluoreto de sódio na progressão de cáries artificiais, obtidas através do modelo de ciclagens de $\mathrm{pH}$, descrito por FEATHERSTONE et $\mathrm{al}^{34}$., em 1986. Neste trabalho, os autores enfatizaram que os testes de microdureza proporcionam a avaliação quantitativa e a comparação de diferentes grupos de tratamento no estudo da progressão ou reversão dos processos de cárie. Dentro dos resultados, observaram que o dentifrício contendo fluoreto de sódio foi extremamente efetivo na redução da progressão de cáries em esmalte, limitando a profundidade do ataque ácido e o grau de perda mineral. Em comparação aos grupos placebo e não tratado, reduziu em torno de 73 a $82 \%$.

No ano seguinte, WHITE ${ }^{107}$ também utilizou o modelo de ciclagem de $\mathrm{pH}$ para avaliar a reatividade de dentifrícios e bochechos fluoretados com a subsuperfície de lesões cariosas in vitro. Os parâmetros de medição da remineralização incluíram absorção de flúor, microdureza superficial e distribuição do 
flúor adquirido pela técnica da microrradiografia. Os resultados do estudo confirmaram a eficácia do flúor tópico na reversão do processo de cárie, na subsuperfície de lesões cariosas, sob condições dinâmicas simulando o meio bucal, uma vez que, a distribuição do flúor adquirido, sugeriu sua incorporação através das lesões. Segundo o autor, um dos resultados surpreendentes do estudo, foi a aparente correlação entre a dureza superficial dos espécimes e o grau de remineralização da subsuperfície, sendo que a remineralização observada teve associação linear com o endurecimento da superfície dos espécimes.

Revendo a literatura a respeito dos estudos in vitro sobre os efeitos do flúor na desmineralização e remineralização, TEN CATE ${ }^{101}$, em 1990, relata que por muitos anos, o papel do flúor na prevenção de cáries foi atribuído principalmente à redução da solubilidade do esmalte, resultante de sua incorporação à apatita. Entretanto, numerosos estudos mostraram que não havia correlação entre os níveis de flúor no esmalte e o aparecimento da cárie. Segundo o autor, a maior evidência disso é que dentes de tubarão, ricos em fluorapatita, podem desenvolver cárie, porém, a formação da lesão pode ser inibida ou paralisada através da incorporação de baixas concentrações de flúor à solução desmineralizante. Embasado nesses achados,o flúor incorporado ao esmalte foi considerado menos efetivo que o flúor disponível em fase líquida, uma vez que, este último, pode promover a inibição da desmineralização do esmalte e um aumento na remineralização da lesão de esmalte. Com relação à metodologia de estudo, chama atenção o fato de que as condições encontradas in vivo podem ser melhores reproduzidas in vitro, quando o sistema de ciclagem de $\mathrm{pH}$ é utilizado, uma vez que, pode simular as quedas de $\mathrm{pH}$ que ocorrem no ambiente bucal.

Uma comparação entre os testes de permeabilidade do iodo, de microdureza Knoop superficial e da análise química da dissolução mineral do esmalte bovino, após desafio ácido, foi conduzida em 1990, por ZERO et al ${ }^{110}$. Durante os procedimentos de desmineralização, os blocos de esmalte eram mantidos imersos, sob agitação constante, em tampão lactato $\mathrm{pH} 4,5$ durante os períodos de 0 (controle), 5, 15, 30 e $45 \mathrm{~min}$. Os autores constataram que a perda mineral foi diretamente proporcional ao tempo de desmineralização. Concluíram que 
tanto o teste de permeabilidade do iodo, quanto o de microdureza, têm sensibilidade para detectar a desmineralização do esmalte em estágios muito precoces. Ambos os testes se associaram, de maneira semelhante, ao processo de dissolução de esmalte, porém o teste de microdureza pareceu ser menos sensível a variações do que o teste de permeabilidade do iodo. Isto porque, mostrou-se menos susceptível a erros do operador e não foi excessivamente influenciado pela porosidade inicial do esmalte, o que eliminou a necessidade de um grande número de espécimes.

HERKSTRÖTER; WITJES;ARENDS ${ }^{52}$, em 1991, estabeleceram uma comparação entre a desmineralização do esmalte e dentina de dentes humanos. Foi realizada uma ciclagem de $\mathrm{pH}$ experimental para diferentes proporções de desmineralização / remineralização e diferentes adições de flúor (0,02, 0,2 e 2 ppm). O conteúdo mineral dos espécimes foi quantificado antes e após cada experimento através microrradiografias de cortes longitudinais. Foi encontrada uma correlação linear entre a quantidade de mineral perdido e o tempo de desmineralização, tanto para o esmalte quanto para a dentina. Sob as condições de ciclagem utilizadas, os autores observaram uma relação logarítmica entre a adição de flúor e a diminuição na desmineralização do esmalte e dentina. A quantidade de flúor, necessária para a total paralisação da desmineralização do esmalte, ficou em torno de 2 ppm; para a dentina entretanto, esta mesma quantidade de flúor não foi suficiente para inibir a desmineralização.

Em 1995, ZERO ${ }^{111}$, através de uma revisão de literatura a respeito de estudos de cárie in situ, teceu alguns comentários a respeito da utilização do substrato de tecido duro. Relatou que o substrato pode ser sadio ou parcialmente desmineralizado, sendo que o esmalte sadio é utilizado para avaliar a extensão da desmineralização ocorrida durante o modelo de estudo e o esmalte parcialmente desmineralizado, para avaliar tanto a desmineralização adicional quanto a ocorrida no modelo. Segundo o autor, dentes humanos deveriam ser considerados a origem dos substratos mais adequada, entretanto, dentes humanos são altamente variáveis no que diz respeito à composição, devido à influência genética, condições ambientais (dieta, exposição ao flúor, desafios cariogênicos anteriores) e idade. Em seu laboratório, o autor elegeu o uso de blocos de esmalte bovinos padronizados 
como substrato de tecido duro para o estudo dos modelos de cárie. Como outras vantagens dos dentes bovinos, citou: facilidade de obtenção, composição mais uniforme, além de apresentar respostas menos variáveis frente aos testes de desafio cariogênico e tratamentos anticariogênicos. Entretanto, chamou a atenção para o fato de que o esmalte bovino é mais poroso do que o esmalte humano e desmineraliza mais rápido, sendo que esta propriedade resulta em diferenças quantitativas e não qualitativas.

Em uma ampla revisão da literatura a respeito dos modelos in vitro para pesquisas sobre desmineralização e remineralização de dentes, WHITE ${ }^{108}$, em 1995, relatou que o progresso de experimentos in vivo e in situ, tem levado muitos pesquisadores a especular a relevância e importância dos protocolos dos testes in vitro nas pesquisas sobre cáries. Portanto, o objetivo de sua revisão foi avaliar as recentes aplicações dos testes in vitro em pesquisas de cáries sobre mineralização e reatividade do flúor. Sugeriu, que a principal vantagem dos estudos in vitro é o fato de proporcionarem ao pesquisador a capacidade de avaliar uma única variável sob condições de estudo controladas; também permitem o estudo mecânico do comportamento dos materiais, o que seria impossível de realizar in vivo, além de proporcionarem a utilização de regras para a padronização do experimento. Como desvantagem dos protocolos in vitro, citou que estes estudos apresentam limitações particularmente relacionadas à incapacidade de simular o complexo processo envolvido na cárie dentária. Contudo, o autor concluiu que experimentos in vitro bem delineados, sobre remineralização, desmineralização e reatividade do flúor, representam o maior foco de pesquisas odontológicas baseadas em mecanismos dentro da prevenção da cárie, apesar dos avanços dos modelos de cárie em animais e em in situ.

Já em 1996, partindo do princípio de que a microrradiografia transversa é um método bem aceito para quantificar a perda mineral durante a formação da cárie dentária, embora seja uma técnica demorada que envolve seccionamento do esmalte $(100 \mu \mathrm{m})$ e a utilização de raio $-\mathrm{x}$, FONTANA et $\mathrm{a}^{35}$, procuraram estabelecer uma correlação entre este método com a técnica de microscopia confocal laser. Uma série de três estudos foi conduzida para correlacionar a 
quantificação da desmineralização obtida de seções de esmalte utilizando a microrradiografia transversa com três parâmetros (área da lesão, intensidade total e média de fluorescência do corante) analisados no microscópio confocal. Os autores concluíram que, em estudos de desmineralização do esmalte, existe uma correlação significante estatisticamente entre os parâmetros medidos utilizando microrradiografia transversa e os parâmetros quantificados usando microscópio confocal.

SCHEMEHORN; WOOD; ROBERTS ${ }^{85}$ em 1996, compararam microdureza superficial e microrradiografia transversa utilizadas para a quantificação da remineralização observada com dentifrícios fluoretados. Fragmentos de esmalte humano com 3mm de diâmetro foram expostos a solução desmineralizante por 72 horas. Em seguida, os espécimes foram submetidos a um regime de remineralização cíclico durante 20 dias. Os resultados deste estudo in vitro indicaram que alterações na dureza superficial deram resultados idênticos às alterações no volume mineral superficial (\%) e resultados semelhantes ao valor da perda mineral.

Um estudo in vitro, sob condições cíclicas de $\mathrm{pH}$, foi conduzido por MAIA $^{65}$, em 1997, com o intuito de avaliar o efeito isolado e/ou da associação da aplicação tópica de fluoretos na remineralização e incorporação de flúor ao esmalte bovino com lesão artificial de cárie. Antes da exposição aos tratamentos e ciclagem de $\mathrm{pH}$, foi medida a microdureza Knoop superficial do esmalte hígido e do esmalte com lesão de cárie incipiente. Após a realização dos experimentos, todos os espécimes tiveram sua microdureza reavaliada e o percentual de remineralização do esmalte foi estimado matematicamente. O flúor incorporado ao esmalte foi determinado através de um eletrodo combinado íon específico, após a remoção de três camadas sucessivas de esmalte com HCL 0,5M. A espessura da camada de esmalte removida durante o ataque ácido foi determinada pela análise colorimétrica do fósforo. Não foi observada correlação significativa entre o percentual de remineralização e o flúor incorporado nos grupos. A autora sugere que a associação de métodos de baixa e alta concentração de flúor não traz, a princípio, benefícios adicionais na remineralização e na incorporação de flúor em esmalte bovino cariado, 
quando comparado com a utilização isolada de baixa concentração com alta freqüência.

AMAECHI; HIGHAM; EDGAR ${ }^{3}$, em 1998, determinaram o efeito da temperatura, duração da exposição, localização sobre a superfície do esmalte e tipo de solução desmineralizante na produção, in vitro, de lesões cariosas em esmalte bovino, para estabelecer as condições para a formação de cáries artificiais em esmalte bovino. Lesões foram produzidas na região incisal, central e cervical das amostras de esmalte, com um sistema de gel acidificado ( $\mathrm{pH} 4,5)$ ou com uma solução ácida tamponada parcialmente saturada $(\mathrm{pH} 4,5)$, nas temperaturas de $20^{\circ} \mathrm{C}$ ou $37^{\circ} \mathrm{C}$, por 3,4 ou 5 dias. A perda mineral e profundidade das lesões foram quantificadas através da digitalização de microrradiografias. Os autores concluíram que lesões de cárie artificial, podem ser conscientemente produzidas em esmalte bovino, com a solução ácida tamponada parcialmente saturada ( $\mathrm{pH} 4,5)$, nas temperaturas de $20^{\circ} \mathrm{C}$ ou $37^{\circ} \mathrm{C}$, durante 3 dias. Com relação à localização da desmineralização sobre a superfície do esmalte, não houve diferença significante entre os sítios, embora variações numericamente maiores tenham ocorrido na região cervical.

TENUTA $^{102}$, em 2001, avaliou a desmineralização do esmalte após períodos de 4, 7 e 10 dias de acúmulo de placa bacteriana in situ, além da influência de fatores salivares e microbiológicos no processo. Após a avaliação do fluxo salivar estimulado, capacidade tampão da saliva e níveis salivares de estreptococos do grupo mutans, dispositivos intrabucais, contendo blocos de esmalte bovino polidos, foram utilizados por voluntários durante os 3 períodos cruzados de teste. A microdureza superficial dos blocos foi determinada antes e após a desmineralização in situ, utilizando um penetrador Knoop. Ao final de cada fase experimental, a placa bacteriana formada sobre os blocos, foi coletada e a porcentagem de estreptococos do grupo mutans, em relação ao número de bactérias totais, foi determinada. Os resultados mostraram desmineralização do esmalte in situ após curtos períodos de acúmulo de placa bacteriana, não tendo sido encontrada relação com os fatores salivares avaliados ou com as contagens de estreptococos do grupo mutans na saliva. 
Com o intuito de determinar a eficácia de verniz fluoretado na inibição da progressão de cáries secundárias, um estudo foi conduzido em 2002 por FONTANA et al. ${ }^{36}$. No primeiro experimento, dentes extraídos, restaurados com amálgama ou resina composta, foram expostos durante 4 dias a um modelo experimental de cárie microbiano. As amostras foram então, tratadas com verniz fluoretado (removido após 24 horas), ou não tratadas (grupo controle), antes de serem expostas por mais 4 dias ao desafio cariogênico. O segundo experimento foi realizado para comparar o efeito que o verniz (com ou sem flúor) apresentava sobre o desenvolvimento de cárie secundária ao redor de restaurações de amálgama. Após os experimentos, os espécimes foram seccionados duas vezes no sentido mésio-distal, perpendicularmente ao longo eixo das restaurações. Um aparelho de microscopia confocal laser foi utilizado para a análise das secções. Os resultados sugeriram que a aplicação precoce do verniz fluoretado, diminuiu significativamente a progressão das lesões cariosas secundárias. Entretanto, a aplicação de um verniz placebo mostrou uma tendência em reduzir a progressão da lesão, sugerindo que o efeito terapêutico do verniz sobre cáries secundárias não seja somente devido a sua liberação de flúor.

\subsection{Materiais restauradores e ação cariostática}

Em 1957, PHILLIPS; SWARTZ78, conduziram uma investigação a respeito do efeito de alguns materiais dentários sobre a solubilidade do esmalte. Foram utilizados superfícies de esmalte íntegro e pó de esmalte, sendo que a solubilidade foi determinada pelas médias de cálcio e fósforo após, o tratamento do esmalte com ácido acético. Observou-se que os cimentos de silicato promoveram diminuição acentuada na solubilidade do esmalte, ao passo que as resinas experimentais e o cimento de fosfato de zinco contendo flúor, promoveram diferentes graus de redução na solubilidade do esmalte. Os autores sugeriram que a menor ocorrência de cárie ao redor das restaurações de cimento de silicato pode ser 
atribuída ao aumento da resistência aos ataques ácidos da estrutura dentária adjacente às restaurações, devido àpresença de flúor.

A liberação de flúor de materiais restauradores e as conseqüentes alterações no conteúdo de flúor do esmalte exposto foram avaliadas em 1960, por NORMAN; PHILLIPS; SWARTZ ${ }^{75}$. Cimentos de silicato, cimento de fosfato de zinco e resinas acrílicas contendo fluoreto de sódio tiveram sua liberação de flúor investigada após a imersão durante 5 dias em água destilada. Para a análise das alterações na concentração de flúor e solubilidade do pó de esmalte dentário, os discos confeccionados com os materiais restauradores foram armazenados, juntamente com $130 \mathrm{mg}$ de pó de esmalte, em $15 \mathrm{~mL}$ de água, durante 5 dias. Os resultados mostraram que a liberação de flúor pelos materiais ocorre relativamente rápido e que a quantidade de flúor liberado diminui com o passar do tempo. Os materiais que liberaram mais flúor aumentaram a incorporação do mesmo no esmalte, enquanto que materiais que não continham flúor reduziram a presença deste elemento no esmalte.

No ano seguinte, NORMAN; PHILLIPS; SWARTZ ${ }^{76}$ partindo do princípio de que os estudos realizados com pó de esmalte, devido ao aumento da área exposta, apresentavam resultados superestimados, conduziram um estudo para avaliar a incorporação de flúor ao esmalte com os mesmos materiais do trabalho anterior além de cimentos de óxido de zinco e eugenol, só que desta vez, utilizando superfícies íntegras de esmalte humano. Os materiais restauradores foram aplicados æ̀s superfícies dentárias e, em seguida, foram imersos por 2 semanas em água destilada a $37^{\circ} \mathrm{C}$. Os resultados mostraram que os materiais que continham flúor em sua composição produziram alterações mensuráveis na quantidade deste incorporado à superfície de esmalte, estando estes dados de acordo com aqueles encontrados anteriormente com a utilização do pó de esmalte. Além disso, encontraram uma relação definitiva entre a alteração da quantidade de flúor e a solubilidade em ácido de esmalte dentário íntegro.

WILSON;KENT ${ }^{109}$, em 1972, descreveram um novo cimento dentário translúcido baseado em uma reação de presa entre pós de vidro de silicato de alumínio e solução aquosa de polímeros e co-polímeros de ácido acrílico. Este 
sistema foi denominado genericamente de cimento de ionômero de vidro e foi desenvolvido com o objetivo de restaurar dentes anteriores, cavidades de erosão, cimentações de um modo geral e forramento de cavidades. Segundo os autores, este material pode ser considerado o sucessor direto do cimento de silicato bem como um tipo especial de compósito, no qual as partículas de carga desempenham um papel importante na formação da matriz. Como principais características destes cimentos, citou-se a boa adesão a bases metálicas e ao esmalte humano, presença de íons flúor, menor solubilidade em ácidos fracos, menor irritação aos tecidos pulpares e maior resistência àtração que o cimento de silicato.

A formação de cáries secundárias ao redor de restaurações de cimento de silicato foi induzida por HALS; NORDEVAL ${ }^{45}$, em 1973. Cavidades classe V foram preparadas em superfícies vestibulares, clinicamente hígidas, de dentes permanentes com indicação de exodontia. Após a realização das restaurações, os dentes receberam bandas ortodônticas para assegurar o acúmulo de placa dentária. O experimento durou de 34 a 326 dias, com um período experimental médio de 131 dias. Depois das exodontias, os dentes foram observados através de microscopia de luz polarizada e microrradiografias. Os autores observaram que lesões de cárie superficial ocorreram em 14 dos 32 casos de risco de cárie secundária e a maioria dos casos mostrou somente discreta desmineralização, que não foi detectada através da microrradiografia. Além disso, houve uma hipermineralização das paredes de esmalte e dentina em cerca de 1/5 dos casos. A baixa suscetibilidade à cárie experimental, associada às restaurações de silicato, foi explicada pela ação do flúor liberado pelo material.

HALLS $^{43}$, em 1975, avaliou o grau e a freqüência de cáries secundárias naturais ao redor de restaurações de cimento de silicato. Setenta dentes permanentes humanos extraídos (incisivos, caninos e um pré-molar), que possuíam cavidades classe $\mathrm{V}$ restauradas com cimento de silicato, foram analisadas através de microscopia de luz polarizada e microrradiografia. O autor pôde observar que o grau e freqüência de cáries secundárias foram baixos quando comparados com estudos anteriores, feitos com restaurações de amálgama. Os resultados mostraram que as superfícies adjacentes æ̀ restaurações, assim como as paredes cavitárias, 
adquiriram um alto grau de resistência àcárie, devido àliberação de flúor do cimento de silicato. Um aumento de radiopacidade, inversamente relacionado ao aparecimento de cáries secundárias, foi percebido nas paredes cavitárias em esmalte e dentina.

A liberação de flúor, in vitro, de um cimento de ionômero de vidro foi comparada com a de um cimento de silicato por FORSTEN ${ }^{38}$, em 1977. Os espécimes foram colocados, sob agitação, em solução contendo hidroxiapatita durante 7 semanas, sendo que as soluções eram trocadas semanalmente e a quantidade de flúor, incorporada pela hidroxiapatita, era medida. Todos os espécimes liberaram consideravelmente mais flúor durante as duas primeiras semanas, em comparação com as semanas seguintes. O cimento de ionômero de vidro liberou uma quantidade de flúor significantemente maior do que cimento de silicato durante a terceira, a quarta e a quinta semana.

MALDONADO; SWARTZ; PHILLIPS ${ }^{66}$, em 1978, investigaram a liberação de flúor, o efeito da solubilidade do esmalte, a adesão ao esmalte e a capacidade de selamento marginal de um cimento de ionômero de vidro em comparação com os cimentos de silicato e policarboxilato. Quanto à liberação de flúor, após 21 dias de imersão em água destilada, puderam observar que o cimento ionomérico liberou quantidades significativamente maiores, tanto em relação à liberação diária quanto à total. A redução na solubilidade do esmalte, avaliada em relação à solubilidade de cálcio, apresentou diferença estatisticamente significante, sendo de $52 \%$ para o cimento de ionômero de vidro e $39 \%$ para o cimento de silicato. Além disso, o ionômero apresentou adesão ao esmalte e dentina mas, como o cimento de policarboxilato, a adesão ao esmalte foi mais forte que àdentina. Com relação ao selamento marginal, o cimento ionomérico foi mais efetivo, mesmo com margens em cemento e dentina. Os autores sugerem que o cimento de ionômero de vidro deve ser tão efetivo quanto o cimento de silicato na prevenção de cáries secundárias.

Uma técnica de formação de cárie artificial, utilizando a difusão controlada por gel acidificado, foi usada por KIDD ${ }^{58}$, em 1978, para investigar a capacidade de selamento marginal de uma resina composta e de um cimento de 
ionômero de vidro. Cavidades classe $\mathrm{V}$ foram preparadas em dentes pré-molares humanos, extraídos por razão ortodôntica. Após a confecção das restaurações e realização dos testes, os espécimes foram avaliados através de microscopia de luz polarizada. A análise dos resultados mostrou que os dois materiais testados apresentaram boa capacidade de selamento. Entretanto, mesmo existindo evidências de uma discreta desmineralização ao longo das paredes cavitárias de algumas amostras restauradas com cimento de ionômero de vidro, as lesões externas observadas ao redor das restaurações foram menos severas, e por isso, o cimento de ionômero de vidro foi considerado pela autora um material cariostático.

Em 1980, WESENBERG; HALS ${ }^{104}$, com o intuito de estudar, in vitro, a estrutura de cáries secundárias em raízes, prepararam cavidades classe $\mathrm{V}$ envolvendo a junção amelo-cementária em dentes humanos e utilizaram o cimento de ionômero de vidro como material restaurador. As cáries artificiais foram produzidas pela exposição dos dentes restaurados à gelatina acidificada, $\mathrm{pH}$ 4,0 pela adição de ácido lático, por um período de 26 a 54 dias. Os espécimes foram seccionados longitudinalmente e analisados por microscopia de luz polarizada e microrradiografias. Os autores observaram uma zona de radiopacidade aumentada nas paredes cavitárias dos dentes, possivelmente devido à precipitação de cálcio e fosfato promovida pela liberação de flúor do material ionomérico.

Ainda no mesmo ano, SWARTZ et al..$^{93}$, determinaram a quantidade de flúor incorporado ao esmalte antes e após a restauração de dentes humanos extraídos com cimento de silicato, de sílico fosfato e ionômero de vidro. As biópsias de esmalte foram realizadas a 1 e $3 \mathrm{~mm}$ das restaurações. Os resultados obtidos após 1, 6 e 12 meses revelaram quantidade de flúor incorporada ao esmalte significativamente maior que nas biópsias realizadas antes das restaurações. Os dentes restaurados com os três materiais apresentaram alterações semelhantes na porcentagem de flúor, levando os autores a concluir que os cimentos de sílicofosfato e de ionômero de vidro possuem potencial de proteção contra as cáries, similar ao cimento de silicato.

Um estudo foi desenvolvido em 1981, por MJÖR ${ }^{67}$, com o objetivo de avaliar as razões para a realização de restaurações e substituição de restaurações 
pré-existentes, em pacientes que procuram tratamento odontológico em clínica particular. De um total de 5.487 restaurações realizadas por 85 dentistas, $74 \%$ eram restaurações de amálgama e $26 \%$ eram restaurações estéticas. Observou que $71 \%$ das restaurações de amálgama e $79 \%$ das restaurações estéticas realizadas eram substituições de restaurações pré- existentes. A principal razão para a substituição de restaurações de amálgama foi o aparecimento de cáries secundárias (em 58\% dos casos). Já para as restaurações estéticas, as principais causas para a substituição foram: forma anatômica insatisfatória, alterações de cor e cáries secundárias.

CRANFIELD; KUHN; WINTER ${ }^{19}$, em 1982, na tentativa de esclarecer melhor os fatores que interferem no grau de liberação de flúor pelo cimento de ionômero de vidro, avaliaram o efeito da proporção pó/líquido, do $\mathrm{pH}$ do meio de imersão e da geometria das amostras. Quatro marcas comerciais de cimentos ionoméricos foram testadas. Os testes de liberação de flúor foram conduzidos durante 13 semanas e os resultados obtidos foram comparados, detalhadamente, aos de outros trabalhos. Os autores relataram que há muitas controvérsias na literatura e concluíram que o mecanismo da liberação de flúor pelo cimento de ionômero de vidro ainda não estava definido.

A liberação de flúor de três marcas comerciais de cimento de ionômero de vidro restaurador e outras três do tipo cimentante foi avaliada in vitro, durante 12 meses por SWARTZ; PHILLIPS; CLARK ${ }^{94}$, em 1984. Os resultados foram comparados aos encontrados para os cimentos de silicato, de sílico-fosfato e policarboxilato contendo flúor. A liberação de flúor dos cimentos de ionômero de vidro foi semelhante à do cimento de silicato, tanto em quantidade, quanto em relação ao padrão, indicando que os cimentos ionoméricos possuem propriedades anticariogênicas similares àquelas do cimento de silicato.

ZIMMERMAN; RAWLS; QUERENS ${ }^{112}$, em 1984, investigaram o desenvolvimento de lesões de cáries artificiais, adjacentes a restaurações de uma resina composta experimental contendo flúor, de uma resina composta convencional e de um cimento de silicato. Cavidades classe $V$ foram preparadas nas superfícies vestibulares e linguais de terceiros molares humanos hígidos e restauradas com os 
materiais citados acima. Após a exposição à gelatina acidificada com pH 4,5 por 17 semanas, os dentes foram seccionados perpendicularmente em relação æ̀s restaurações e as lesões foram analisadas sob microscopia de luz polarizada. Os resultados mostraram que a desmineralização ao redor da resina composta experimental foi significativamente menor que a encontrada para o compósito convencional e, menor ou igual à do cimento de silicato. Em geral, o grau de proteção aumentou com o aumento do conteúdo de flúor na resina experimental. Os autores concluíram que, embora algumas propriedades tenham que ser melhoradas antes do uso clínico do protótipo do material experimental, este se mostrou promissor pela ação de barreira contra a desmineralização e como fonte de liberação de flúor.

BRANDAU; ZIEMIECKI; CHARBENEAU ${ }^{8}$, em 1984, avaliaram as características clínicas de um cimento de ionômero de vidro quando utilizado para restaurar dentes, cujas regiões cervicais apresentavam contornos anatomicamente deficientes, sem a confecção de preparos cavitários ou retenções adicionais. Após 54 meses, 75\% das restaurações estavam completamente retidas e apenas 10\% dos dentes perderam totalmente as restaurações. Não foram observadas alterações na cor de $88 \%$ das restaurações. As restaurações apresentaram contorno anatômico aceitável em $80 \%$ dos casos. Não houve evidências de cárie nas margens de nenhuma das restaurações.

Com o objetivo de avaliar a incorporação de flúor em cemento e esmalte, RETIEF et al. ${ }^{84}$, em 1984, prepararam cavidades classe $\mathrm{V}$ envolvendo a junção cemento-esmalte na superfície vestibular de 45 incisivos centrais humanos extraídos. Os preparos cavitários foram restaurados com o cimento de ionômero de vidro Fuji II. A incorporação de flúor, em áreas de cemento e esmalte, localizadas a diferentes distâncias das margens das restaurações, foi analisada após 1, 3 ou 6 meses de imersão em saliva artificial a $37^{\circ} \mathrm{C}$. Os resultados das biópsias mostraram que o flúor incorporado ao esmalte após 1 mês foi retido nos períodos de 3 e 6 meses. Houve uma tendência da quantidade de flúor adquirido pelo esmalte diminuir àmedida que os sítios de biópsia se afastavam do cimento ionomérico. No cemento, a incorporação de flúor foi reduzida significativamente após 3 meses em 
comparação a 1 mês, mas não diferiu significativamente do período de 6 meses. Os autores puderam concluir que, tanto o esmalte quanto o cemento, incorporaram quantidades substanciais de flúor liberado pelo cimento de ionômero de vidro.

DERAND; JOHANSSON ${ }^{24}$, em 1984, avaliaram as diferenças no desenvolvimento de lesões artificiais de cárie ao redor de restaurações em superfícies radiculares confeccionadas com: um amálgama (ANA 2000), contendo ou não flúor em sua composição, um cimento de ionômero de vidro (Chem-fil), um cimento de óxido de zinco eugenol (IRM), uma resina composta (Profile) e um cimento de silicato (Syntrex). Após a realização das restaurações, os espécimes foram expostos individualmente a uma solução contendo $12 \%$ de gelatina acidificada, $\mathrm{pH}$ 4,0, por períodos de 2, 4 e 7 semanas. Em seguida, foram seccionados longitudinalmente e avaliados através de microrradiografia e microscopia de luz polarizada. A análise dos resultados mostrou que, ao redor de cavidades restauradas com materiais que liberaram flúor, as lesões encontradas foram significativamente menores e que a proteção contra o desafio cariogênico foi mais evidente em dentes restaurados com cimento de silicato e cimento de ionômero de vidro.

A freqüência de cáries secundárias em diferentes localizações anatômicas foi pesquisada por $\mathrm{MJÖR}^{68}$ em 1985. O autor observou que das 1570 restaurações realizadas por 28 dentistas, em um período de 2 semanas, 872 eram substituições de restaurações já existentes. A razão dessas substituições, em $72 \%$ dos casos de restaurações de amálgama e $43 \%$ de restaurações de resina composta, foi cárie secundária. Além disso, as cáries recorrentes apareceram mais freqüentemente nas margens cervicais e proximais do que nas margens incisais ou oclusais.

Em 1986, HICKS; FLAITZ; SILVERSTONE ${ }^{53}$, estudaram in vitro, a formação de cáries secundárias ao redor de restaurações de cimentos de ionômero de vidro realizadas na superfície coronária de dentes humanos extraídos. As lesões de cáries artificiais foram induzidas por meio da exposição por 10 semanas a uma gelatina acidificada com pH 4,2. Após este período, os espécimes foram submetidos a 3 secções longitudinais, as quais foram avaliadas sob microscopia eletrônica de 
varredura e de luz polarizada. Análises da interface esmalte / restauração mostraram que o cimento de ionômero de vidro proporcionou proteção contra a formação de cárie secundária, não havendo formação de lesões de parede. As lesões encontradas na superfície de esmalte adjacente ao cimento ionomérico foram significantemente menores, quando comparadas a lesões controle. Os autores concluíram que, restaurações com cimentos de ionômero de vidro podem ser de grande importância na prevenção de cáries secundárias e, de cáries primárias em superfícies adjacentes a restaurações.

Uma avaliação do comportamento clínico de 7 resinas compostas indicadas para dentes anteriores, realizada durante um período de 6 anos, foi publicada por van DIJKEN ${ }^{25}$, em 1986. Foram investigadas a descoloração extrínseca, alterações de cor, descoloração marginal, adaptação marginal, rugosidade superficial e cáries secundárias. O incremento de cárie individual foi comparado com uma estimativa do risco de cárie dos voluntários, baseado em contagens de microorganismos, higiene bucal, fluxo salivar, capacidade tampão e ingestão de carboidratos fermentáveis. O aparecimento de cáries secundárias foi o principal motivo para a substituição e acometeu as margens em 18,9\% das restaurações. Além disso, os pacientes portadores de vários fatores de risco apresentaram maior incremento de cárie.

KAMBHU; ETTINGER; WEFEL ${ }^{57}$, em 1988, estudaram a resistência à cárie de dentes que tiveram o orifício do conduto radicular obturado com: amálgama, amálgama após aplicação de duas camadas de verniz, resina composta com um agente de união, cimento de ionômero de vidro restaurador e uma mistura de cimento de ionômero de vidro com limalha. Todos os espécimes foram submetidos a termociclagem durante 1500 ciclos. A formação das lesões de cárie artificiais foi induzida por gelatina acidificada com pH 4,3 durante 4 semanas. As lesões adjacentes æ̀s restaurações foram avaliadas através de microscopia de luz polarizada e microrradiografias. Os resultados mostraram que as lesões ao redor das restaurações de cimento de ionômero de vidro apresentaram profundidades médias significativamente menores que as lesões adjacentes aos outros materiais 
restauradores. Os autores concluíram que o cimento de ionômero de vidro estudado apresentou in vitro, efeito inibidor da desmineralização.

PURTON; RODDA ${ }^{83}$, em 1988, produziram lesões de cárie artificial adjacentes a restaurações de resina composta e de cimento de ionômero de vidro em raízes de dentes humanos extraídos. Após as restaurações, os dentes foram expostos a ácido lático com pH 4,5 contendo $0,25 \mathrm{mM}$ de tri-polifosfato de sódio, por 15 dias, para a produção das cáries artificiais. Os dentes foram seccionados longitudinalmente e os cortes foram avaliados por meio de microscopia de luz polarizada e microrradiografias. Os resultados mostraram que o cimento de ionômero de vidro, mesmo apresentando solubilidade em meio ácido, promoveu a precipitação de minerais na lesão.

Ainda no mesmo ano, ARENDS; RUBEN ${ }^{4}$ compararam a liberação de flúor de um cimento de ionômero de vidro, de uma resina composta convencional e de uma resina composta contendo flúor em sua composição. A liberação de flúor foi avaliada durante quatro semanas com os espécimes imersos em água e em solução saturada de cálcio e fosfato com pH 5,0. Os resultados mostraram que o cimento de ionômero de vidro liberou quantidades de flúor significativamente maiores que as resinas em ambos os meios de imersão.

Revendo na literatura estudos relacionados aos efeitos dos cimentos de ionômero de vidro no desenvolvimento de cáries secundárias, SWIFT JR ${ }^{96}$, em 1989, constatou que a liberação lenta e contínua de flúor pode reduzir a ocorrência de cáries secundárias e a severidade das lesões adjacentes a esses materiais.

HATTAB; MOK; AGNEW ${ }^{50}$, em 1989, avaliaram a capacidade de vários materiais restauradores de resistir ao desafio cariogênico. Cavidades classe $V$, preparadas em dentes permanentes humanos extraídos, foram restauradas com amálgama com ou sem flúor, cimento de ionômero de vidro convencional, cermet e uma resina composta. Para a produção de lesões artificiais de cárie os dentes foram imersos, durante 12 semanas, em gel acidificado com pH ajustado para 4,0, adicionando-se ácido lático. A avaliação da extensão das lesões foi feita por meio de microscopia de luz polarizada. Os resultados mostraram que a ocorrência de lesões de parede foi de $9,5 \%$ para o cermet, $35 \%$ para o amálgama com flúor, $46 \%$ para o 
amálgama convencional e 100\% para a resina composta. O cimento de ionômero de vidro convencional impediu o desenvolvimento de lesões de parede, além de proporcionar a menor ocorrência de lesões externas.

Ainda em 1989, SWIFT JR. ${ }^{97}$, comparou o padrão e a quantidade de flúor liberado por duas resinas compostas contendo flúor em sua composição e um cimento de ionômero de vidro convencional indicado para restauração. As variáveis foram estudadas durante o período de 2 semanas de imersão dos espécimes em água destilada. Os resultados mostraram que o padrão de liberação de flúor foi semelhante para os três materiais. Houve diferenças significativas nas concentrações de flúor liberado, sendo que o cimento de ionômero de vidro liberou maiores quantidades de flúor que os demais materiais.

A prevenção da desmineralização do esmalte adjacente a restaurações e a liberação de flúor de dois cimentos de ionômero de vidro convencionais, um cermet e uma resina composta, foram estudados em 1990, por FORSS; SEPPÄ ${ }^{37}$. Blocos de esmalte humano foram restaurados e submetidos a ciclagens de desmineralização e remineralização durante 9 dias. Os blocos eram mantidos durante 30 minutos na solução desmineralizante , a qual era constituída de um tampão hidróxido de sódio, contendo ácido lático com pH 5,0. Após a ciclagem des-re, a quantidade de flúor liberado na solução remineralizante, que consistia de saliva artificial, foi determinada pelos períodos de 1, 3, 5 e 9 dias. O flúor incorporado no esmalte adjacente æ̀s restaurações, antes e após a ciclagem, foi determinado pelo método de biópsia de esmalte. A capacidade dos materiais em prevenir a desmineralização, foi avaliada por meio de testes de microdureza superficial, utilizando diamante tipo Vickers e carga de $200 \mathrm{~g}$. Os resultados sugeriram que os cimentos de ionômero de vidro liberaram quantidades significantes de flúor e que estes materiais podem prevenir a desmineralização do esmalte ao redor da restauração. Os ionômeros convencionais se mostraram mais efetivos que o cermet na prevenção da desmineralização.

FORSTEN ${ }^{39}$, em 1990, determinou a liberação de flúor, durante 2 anos, de sete cimentos de ionômero de vidro restauradores e de um indicado para selamento, comparando-os a um amálgama com flúor e a uma resina composta, 
também contendo flúor. Após um período de estocagem de 24h, os espécimes foram continuamente expostos a água de abastecimento não fluoretada. Durante todo o período de estudo, os cimentos de ionômero de vidro liberaram flúor, sendo que esta liberação pareceu manter-se em um nível capaz de proporcionar um efeito anticariogênico. O amálgama liberou, nos primeiros 2 meses quantidade de flúor semelhante ao cermet porém, sendo desprezível após um ano. A resina composta liberou mais flúor que o amálgama, entretanto os cimentos ionoméricos liberaram flúor em quantidades significantemente maiores que estes dois materiais.

Ainda em 1990, KOCH; HATIBOVIC-KOFMAN ${ }^{61}$, em um estudo in vivo, avaliaram a liberação de flúor em saliva de diferentes cimentos de ionômero de vidro e analisaram o número de Unidades Formadoras de Colônias de estreptococos do grupo mutans presentes na saliva antes e após a realização das restaurações. Trinta e seis crianças com idades entre 3 e 11 anos, que necessitavam de tratamento odontológico restaurador em dentes decíduos, e que não tinham restaurações prévias com ionômero de vidro, receberam de 1 a 6 restaurações. A saliva foi coletada antes da realização das restaurações, imediatamente após, e 3 e 6 semanas mais tarde. Após 3 semanas, a concentração de flúor liberado diminuiu cerca de $35 \%$ para todos os materiais. Após 6 semanas, a concentração estava $30 \%$ menor, mas ainda era 10 vezes maior que no início do experimento. Os autores concluíram que as restaurações de ionômero de vidro aumentaram a concentração de flúor na saliva por um período considerável de tempo, e que este sistema de liberação lenta de flúor, por longos períodos, pode significar uma medida efetiva na prevenção de cáries. Além disso, a colocação de restaurações de cimentos ionoméricos diminuiu a prevalência de estreptococos do grupo mutans em saliva.

Já em 1991, HATIBOVIC-KOFMAN; $\mathrm{KOCH}^{47}$, dando continuidade ao trabalho anterior, avaliaram a liberação de flúor de restaurações realizadas com os mesmos materiais após 1 ano e também estudaram in vitro, a liberação reincorporação - liberação de flúor dos materiais durante 16 semanas. A concentração de flúor em saliva que era de 0,04 ppm antes da realização das restaurações, após 3 semanas aumentou para 0,8 ppm, permaneceu em concentrações altas como 0,4 ppm após 6 semanas e 0,3 ppm e após 1 ano. Os 
testes laboratoriais mostraram que durante as 3 primeiras semanas, o cimento de ionômero de vidro modificado por resina liberou consideravelmente mais flúor que os cimentos ionoméricos convencionais. $\mathrm{Na} 11^{\mathrm{a}}$ semana, as diferenças entre os materiais não foram significativas. $\mathrm{Na} 12^{\mathrm{a}}$ semana, os espécimes foram tratados com um dentifrício contendo 250 ppm de flúor. Logo após a exposição ao dentifrício, a concentração de flúor liberado foi bastante elevada, diminuindo gradualmente, apresentando padrão semelhante ao anterior. Este estudo in vitro, mostrou que os cimentos de ionômero de vidro avaliados têm a capacidade de absorver flúor de um dentifrício e liberá-lo mais tarde, agindo como um dispositivo recarregável de liberação lenta.

HATTAB et al. ${ }^{49}$, em 1991, estudaram in vivo a liberação de flúor em saliva de um cimento de vidro convencional. O material restaurador foi inserido em dispositivos maxilares intrabucais, confeccionados em acrílico, utilizados por voluntários durante a noite. O experimento foi conduzido durante 8 dias consecutivos. Amostras de saliva não estimulada eram coletadas antes dos indivíduos se deitarem à noite e pela manhã, após o uso do dispositivo. Os resultados mostraram que houve um aumento estatisticamente significativo na concentração de flúor na saliva de todos os voluntários, após a utilização dos dispositivos contendo corpos de prova de cimento de ionômero de vidro. Os autores concluíram que a proporção quase constante de flúor, liberado durante o período teste, sugere que o cimento de ionômero de vidro pode proporcionar proteção contra o aparecimento de cáries secundárias.

A liberação de flúor, através de corpos de prova confeccionados com: cimento de ionômero de vidro convencional, cermet e resina composta contendo flúor, após o tratamento com flúor tópico, foi avaliada por FORSTEN ${ }^{40}$ em 1991. Após 7 meses do armazenamento em água corrente, os espécimes foram mantidos durante 1 semana em solução tamponada, contendo 50 ppm de flúor, enquanto que os espécimes controle ficaram imersos em água deionizada. Em seguida, os corpos de prova foram expostos a água corrente por 24 horas, e a liberação de flúor foi medida na semana seguinte. Após 15 meses em água corrente, os corpos de prova que haviam sido tratados anteriormente com flúor, foram mantidos por 24 horas na 
solução fluoretada e então, foram expostos a água corrente por mais 24 horas, antes que a liberação de flúor fosse medida por mais 1 semana. Os resultados mostraram que os espécimes de cimento de vidro convencional e de cermet tratados com flúor, liberaram mais flúor do que os não tratados, sendo que o mesmo efeito não foi observado para a resina composta.

TYAS $^{103}$, em 1991, publicou um estudo no qual comparou, durante 5 anos, o desempenho clínico de um cimento de ionômero de vidro convencional, indicado para restauração, com o de uma resina composta, colocados em cavidades classe $\mathrm{V}$ originadas de processo carioso. Após os 5 anos, 1\% das restaurações de ionômero e $6 \%$ das restaurações de resina apresentaram cárie e o manchamento marginal ao redor do compósito foi praticamente o dobro do observado com o cimento ionomérico. O comportamento do cimento de ionômero de vidro neste estudo clínico longitudinal sugere que sua utilização possa diminuir o potencial de desenvolvimento de cáries secundárias.

Um estudo foi conduzido em 1992, por SERRA; CURY ${ }^{88}$, com objetivo de avaliar as diferenças na iniciação e progressão de cáries secundárias em esmalte ao redor de restaurações. Cavidades foram preparadas no terço médio da face vestibular de pré-molares humanos e foram restauradas com uma resina composta (Herculite) e com um cimento de ionômero de vidro restaurador (Ceram-Fil). Para simular as condições de alto desafio cariogênico encontradas in vivo, um modelo dinâmico de ciclagens de desmineralização e remineralização foi utilizado para a indução das cáries experimentais ao redor das restaurações. Os efeitos dos materiais restauradores foram comparados através de testes de microdureza Knoop em cortes longitudinais, passando através do centro das restaurações. Os autores observaram que o cimento de ionômero de vidro mostrou um valor potencial como material restaurador para a prevenção ou controle de cáries em esmalte adjacente a restauração, mesmo em situações de alto desafio cariogênico. Além disso, o uso de resina composta não preveniu o desenvolvimento de cáries artificiais sobre o esmalte adjacente às restaurações, sugerindo a necessidade de medidas preventivas adicionais quando um material sem ação cariostática é utilizado. Os autores também concluíram que a indicação do cimento de ionômero de vidro como 
material restaurador, adquire importância particular na prevenção de cáries secundárias, nos indivíduos de alto risco de cárie.

BENELLI et al. ${ }^{6}$, em 1993, compararam a quantidade de flúor na placa dentária formada sobre cimento de ionômero de vidro ou resina composta e avaliaram os efeitos da liberação de flúor sobre o crescimento de microbiota cariogênica, na absorção de flúor e na formação de cáries secundárias in situ, sob condições de alto desafio cariogênico. Dez voluntários adultos participaram deste estudo cruzado, realizado em duas etapas de 28 dias. Oitenta blocos de esmalte foram restaurados aleatoriamente com um cimento de ionômero de vidro (Chelon-Fil) e uma resina composta (Silux). Os níveis de flúor, estreptococos do grupo mutans e lactobacilos foram avaliados na placa dentária. A incorporação de flúor e os perfis de microdureza Knoop em secções longitudinais foram determinados no esmalte ao redor das restaurações. A análise dos resultados mostrou níveis de flúor significantemente mais altos e o menor nível de estreptococos do grupo mutans na placa formada sobre o cimento de ionômero de vidro. A incorporação de flúor foi significativamente maior e a perda mineral foi significativamente menor ao redor das restaurações com cimento de ionômero de vidro. Estes resultados mostraram que o cimento de ionômero de vidro apresenta um amplo efeito anticariogênico, o qual deve ser considerado na prevenção de cáries secundárias, principalmente em condições de alto risco de cárie.

A liberação de flúor, in vitro, de vários cimentos de ionômero de vidro e resinas compostas, após a exposição a soluções de fluoreto de sódio, foi estudada por TAKAHASHI; EMILSON; BIRKED ${ }^{98}$, em 1993. Corpos de prova cilíndricos foram preparados, imersos em água destilada e após 5 semanas, divididos em quatro grupos para serem expostos, durante 5 minutos, a soluções contendo somente água destilada (controle) e 0,02; 0,2 ou $2 \%$ de fluoreto de sódio. A quantidade de flúor liberado foi quantificada por mais 5 semanas. Após a realização do experimento, foi constatado que dentre os materiais restauradores estudados, não houve diferenças significantes entre o cimento de ionômero de vidro convencional e o modificado por resina, os quais liberaram significativamente mais flúor que as resinas compostas. Diferenças estatísticas também não foram observadas entre a resina composta com 
flúor e a convencional. Além disso, os autores observaram que após a exposição à solução de fluoreto de sódio a $2 \%$, houve um aumento significativo na liberação de flúor dos diferentes tipos de cimentos ionoméricos, o mesmo não ocorrendo com as resinas compostas.

Em 1994, CAO et al. ${ }^{14}$, compararam a liberação de flúor de resinas compostas contendo flúor em sua composição, compômeros, cimentos de ionômero de vidro convencionais e modificados por resina. A quantidade de flúor liberada em água destilada foi dosada semanalmente durante 4 meses. Os resultados mostraram que os materiais apresentaram uma grande liberação no início, a qual diminuiu exponencialmente nas 2 primeiras semanas e, a partir de então, percebeu-se um declínio mais lento. De um modo geral, os cimentos de ionômero de vidro, principalmente os convencionais, foram os materiais que liberaram mais flúor durante os 4 meses. Os compômeros e as resinas compostas liberaram as menores quantidades. Os autores ainda consideraram que a liberação de flúor depende do tipo de material e da formulação de cada marca comercial.

Uma revisão das pesquisas in vitro, relacionadas à inibição da desmineralização e promoção da remineralização do esmalte e dentina, devido à liberação de flúor de materiais restauradores, foi realizada por DONLY²8, em 1994. Os trabalhos analisados mostraram que os materiais restauradores com flúor na sua composição podem agir como um sistema de liberação de flúor, agindo em sinergismo com bochechos e dentifrícios fluoretados na remineralização de lesões incipientes de cárie. O flúor liberado por meio de restaurações demonstrou inibir a desmineralização e equilibrar a remineralização da estrutura dentária adjacente à restauração. O autor sugere, através dos dados estudados, que a utilização clínica de materiais liberadores de flúor pode proporcionar resistência contra o aparecimento de cáries secundárias.

BROOKS et al. ${ }^{10}$, em 1994, avaliaram a liberação de flúor de um cimento de ionômero de vidro convencional (Fuji II) e um modificado por resina (Fuji II LC) , comparando a manipulação manual com a mecânica. A liberação de flúor foi avaliada por um período de 28 dias. A análise dos resultados mostrou que 0 cimento de ionômero de vidro modificado por resina liberou significativamente mais 
flúor que o convencional. Não foi observada diferença significante entre a manipulação manual e mecânica.

O efeito in vitro, de três cimentos de ionômero de vidro modificados por resina e de um convencional sobre o desenvolvimento de cáries secundárias, foi avaliado por NAGAMINE et al. ${ }^{70}$ em 1994. Após as restaurações de cavidades classe $\mathrm{V}$, preparadas na junção cemento-esmalte de pré-molares extraídos, os espécimes foram incubados em meio inoculado com estreptococos do grupo mutans, a $37^{\circ} \mathrm{C}$ por 20 dias. Em seguida, cortes axiais foram realizados nos corpos de prova para a análise em microrradiografias. Além disso, a liberação de flúor em água, após 2 e 28 dias, também foi avaliada. Não foi observada diferença estatisticamente significante em relação àprofundidade das lesões, entre dois tipos de ionômeros estudados. Os autores também concluíram que o efeito de inibição de cáries secundárias dos cimentos de ionômero de vidro modificados por resina não foi diretamente relacionado àquantidade de flúor liberada por eles.

BYNUM; DONLY ${ }^{12}$, em 1994, investigaram a capacidade de inibição de cáries secundárias ao redor de restaurações de alguns materiais restauradores. Cavidades classe $\mathrm{V}$ foram preparadas em dentes humanos extraídos e restauradas com dois cimentos de ionômero de vidro modificados por resina e amálgama. Todos os espécimes foram submetidos a 5 dias de desafio cariogênico com pH 4,4 e, em seguida, foram seccionados longitudinalmente para que as áreas desmineralizadas, adjacentes às restaurações, fossem analisadas por meio de microscopia de luz polarizada. Segundo os autores, lesões de parede em esmalte e dentina foram observadas, respectivamente, em $80 \%$ e $90 \%$ das restaurações de amálgama. Não foi constatada diferença significante entre os dois cimentos ionoméricos estudados, uma vez que foi observada, tanto em esmalte quanto em dentina, zona de inibição em $100 \%$ dos casos.

Ainda em 1994, um estudo foi conduzido por CREANOR et $\mathrm{al}^{20}$. com o objetivo de investigar a capacidade de liberação e incorporação de flúor de três cimentos de ionômero de vidro convencionais e dois modificados por resina. A liberação de flúor em água foi monitorada por um período de 60 dias. Para o estudo da incorporação de flúor, os espécimes foram colocados em 1 litro de água 
deionizada por 60 dias e, em seguida, metade dos espécimes foi exposta a uma solução de 1000 ppm de flúor, por 2 minutos, durante 20 dias, sendo que a outra metade das amostras não foi exposta ao tratamento com flúor, ficando como controle. De acordo com os resultados obtidos, todos os materiais liberaram quantidades mensuráveis de flúor, sendo que o cimento de ionômero de vidro modificado por resina, Vitrebond, liberou quantidades de flúor significativamente maiores que os demais materiais. A exposição dos corpos de prova à solução fluoretada aumentou consideravelmente a liberação de flúor de todos os materiais estudados, indicando, segundo os autores, que os cimentos ionoméricos podem incorporar flúor extrínseco e posteriormente liberá-lo.

FORSTEN ${ }^{41}$, em 1995, avaliou a liberação de flúor de cimentos de ionômero de vidro modificados por resina e de resinas compostas modificadas por poliácidos ou compômeros. Os corpos de prova foram continuamente expostos a água corrente por períodos que variaram de 1 a 11 meses. Os resultados mostraram que os cimentos de ionômero de vidro modificados por resina liberaram tanto ou mais flúor que o cimento de ionômero de vidro convencional, utilizado como controle. Além disso, a exposição dos corpos de prova de 9 meses de idade a uma solução contendo 50 ppm de flúor, durante 1 semana, aumentou a quantidade de flúor liberado tanto pelo cimento de ionômero de vidro convencional, quanto pelos modificados por resina. Por outro lado, os compósitos modificados por poliácidos liberaram flúor em quantidades muito menores que os outros materiais e não sofreram influência do tratamento com flúor.

Em um artigo a respeito dos cimentos de ionômero de vidro modificados por resina e suas características, SIDHU; WATSON ${ }^{89}$, em 1995, relataram que estes materiais são híbridos dos cimentos de ionômero de vidro convencional com pequena adição de resina fotopolimerizável, e que, conseqüentemente, apresentam propriedades intermediárias dos dois materiais, com algumas características superiores ao cimento ionomérico convencional. Geralmente, apresentam características de ambos, como adesão à estrutura dentária, estética, liberação de flúor e presa rápida pela luz visível. Possuem ainda a reação fundamental de presa ácido-base a qual é acrescentada um processo de 
presa secundária iniciada pela luz, embora seja característica sine qua non que estes materiais tomem presa na ausência de luz. Com relação àliberação de flúor e efeito cariostático, os autores encontraram na literatura revista, que os cimentos de ionômero de vidro modificados por resina liberam pelo menos as mesmas quantidades de flúor que os convencionais, o que varia de acordo com a formulação das diferentes marcas comerciais. Consideraram também, que esta alteração na formulação dos ionômeros convencionais, não afetou adversamente a propriedade de inibição de cáries, atribuída à liberação de flúor, sendo esta uma vantagem dos cimentos de ionômero de vidro modificados por resina sobre as resinas compostas. Outros fatores relacionados às propriedades físicas, tais como, mecanismo de adesão, sensibilidade àágua, desgaste e resistência, ainda precisam ser mais bem avaliados, embora tenham ressaltado que os materiais disponíveis apresentem futuro promissor.

Com o intuito de avaliar o efeito cariostático de materiais restauradores contendo flúor, SERRA ${ }^{87}$, em 1995, preparou cavidades classe $V$ em fragmentos de esmalte humano, divididos aleatoriamente em 9 grupos: grupo controle e os restaurados com Z-100, Heliomolar, Tetric, Dyract, Variglass, Vitremer, Photac-fil e Ketac-fil. Após os procedimentos restauradores, todos os espécimes, exceto os do grupo controle, foram submetidos a ciclagens de desmineralização e remineralização, durante 14 dias, de acordo com a metodologia proposta por Featherstone em 1986. Em seguida, os blocos de esmalte foram seccionados longitudinalmente, através do centro das restaurações, e as diferenças no desenvolvimento das lesões experimentais de cáries adjacentes aos materiais restauradores foram quantificadas através do teste de microdureza Knoop. A autora concluiu que, sob as condições estudadas, o cimento de ionômero de vidro convencional apresentou maior potencial cariostático que os materiais híbridos de ionômero de vidro/resina composta. Os compósitos avaliados, mesmo aqueles contendo flúor em sua composição, não demonstraram efeito anticariogênico.

$\operatorname{COSTA}^{17}$, em 1995, avaliou in vitro a atividade antimicrobiana de um cimento de ionômero de vidro restaurador convencional (Chelon Fil) e um modificado por resina (Vitremer), um cermet (Chelon Silver) e um compômero (Variglass), 
correlacionando-a com a liberação de flúor pelos mesmos. A liberação de flúor em água, foi medida diariamente por 14 dias. Paralelamente, por um período de 7 dias, em amostras igualmente padronizadas dos materiais, analisou-se a atividade antimicrobiana. Os resultados mostraram que, no período de 14 dias, o Chelon Fil liberou as maiores quantidades totais de flúor, seguido pelo Vitremer, Chelon Silver e Variglass. Todos os materiais apresentaram o mesmo padrão de liberação, sendo esta maior nas primeiras 24 horas. Somente o Vitremer reduziu significativamente a produção de ácidos nas primeiras 24 horas. Em relação ao controle, houve um menor acúmulo de carboidratos sobre todos os cimentos, porém, com quantidades significantemente menores apenas sobre o Vitremer.

Um artigo de revisão foi publicado por KILPATRICK ${ }^{59}$, em 1996, abordando as aplicações dos cimentos de ionômero de vidro em Odontopediatria. $\mathrm{O}$ autor considera que o tratamento odontológico para o paciente infantil deveria ser rápido, simples, aceitável, indolor e suficientemente durável. Entretanto, relatou que ainda não há um material capaz de preencher todos estes requisitos, mas chamou atenção para os cimentos de ionômero de vidro, os quais apresentam duas propriedades consideradas chave: a capacidade de se aderir quimicamente ao esmalte e dentina e a liberação de flúor. No que diz respeito ao uso do ionômero como selante de fóssulas e fissuras, encontrou consideráveis evidências in vitro de que este material é capaz de reduzir a extensão da desmineralização ao redor de restaurações. Além disso, também encontrou evidências tanto in vivo como in vitro que os cimentos ionoméricos não somente previnem a formação de novas lesões cariosas, como favorecem a remineralização de lesões pré-existentes. Outra indicação do cimento de ionômero de vidro ressaltada pelo autor neste artigo, seria a cimentação de dispositivos ortodônticos, uma vez a liberação de flúor destes materiais poderia reduzir a quantidade de desmineralização ao redor dos dispositivos.

HATIBOVIC-KOFMAN; KOCH; EKSTRAND ${ }^{46}$ em 1997, partindo do princípio de que a liberação de flúor por cimentos de ionômero de vidro está bem estabelecida e de que esta liberação depende de propriedades físicas e químicas de cada produto, avaliaram a liberação de flúor e a capacidade de recarga de cinco 
diferentes marcas de cimento de ionômero de vidro. Todos os materiais utilizados no estudo eram indicados para forramento, sendo que quatro deles eram modificados por resina e somente um era do tipo convencional. A liberação de flúor em água deionizada foi medida, através do método de Taves, uma vez por dia durante 11 dias. Para os teste de recarga, os espécimes foram imersos no $11^{\circ}, 16^{\circ}, 21^{\circ}$ e $26^{\circ}$ dia em soluções com diferentes concentrações de $\mathrm{NaF}$, durante 5 minutos. A liberação de flúor dos espécimes recarregados foi medida até o $32^{\circ}$ dia. Os autores encontraram uma correlação positiva entre a quantidade de flúor originalmente incorporada ao material e sua capacidade de liberação. O cimento de ionômero de vidro convencional estudado liberou significantemente menos flúor e mostrou a menor capacidade de recarga que os outros materiais. Todos os materiais estudados mostraram-se capazes de incorporar e liberar flúor, mas a liberação inicial de flúor apresentada pelos materiais, não foi completamente resgatada após a exposição æ̀s soluções fluoretadas.

ABDALLA; ALHADAINY; GARCIA-GODOY ${ }^{1}$ em 1997, avaliaram o comportamento clínico de duas resinas compostas modificadas por poliácidos (Dyract e Compoglass) e dois cimentos de ionômero de vidro modificados por resina (Fuji II LC melhorado e Vitremer) em cavidades classe V. Cento e vinte cavidades, com margem gengival terminando $1 \mathrm{~mm}$ abaixo da junção cemento-esmalte, foram preparadas em dentes anteriores e posteriores. Com cada material foram restauradas trinta cavidades. As restaurações foram avaliadas, independentemente, por dois examinadores através do critério USPHS (Serviço de Saúde Pública dos EUA) após uma semana, um ano e dois anos. Os resultados demonstraram que todos os materiais apresentaram aceitável comportamento clínico quando colocados em cavidades classe V. Nenhuma cárie foi observada durante os períodos de avaliação. Entretanto, as resinas compostas modificadas por poliácidos mostraram melhor comportamento clínico que os cimentos de ionômero de vidro modificados por resina.

Com o objetivo de avaliar o efeito à distância de um cimento de ionômero de vidro modificado por resina sobre a formação de cáries artificiais em esmalte bovino, um estudo in vitro foi conduzido em 1997, por TANTBIROJON; 
DOUGLAS; VERSLUIS ${ }^{99}$. Como parâmetro para comparação os autores também utilizaram uma resina (bis-GMA), pois este material tem sido amplamente utilizado na prevenção de cáries de cicatrículas e fissuras. Os materiais foram aplicados no terço cervical da superfície vestibular de incisivos bovinos. Para a produção das lesões cariosas, os espécimes foram imersos, separadamente, em ácido lático gel, durante 3 semanas. As lesões foram avaliadas através de testes de microdureza Knoop em secções longitudinais. A microdureza foi avaliada a diferentes distâncias das margens do preparo. Os resultados mostraram que o cimento de ionômero de vidro modificado por resina, Vitremer, proporcionou um forte efeito inibidor sobre a desmineralização na área adjacente à restauração e um efeito remoto, o qual retardou a progressão da lesão artificial a uma distância considerável $(1,0 \mathrm{~mm})$. Segundo os autores, estes achados podem suportar a idéia de que um selante o qual inibe cáries passivamente obturando a fissura, pode também estender o efeito anticárie através da liberação de flúor.

SEGURA et al. ${ }^{86}$, em 1997, avaliaram a remineralização de lesões incipientes de cárie na região interproximal de dentes adjacentes a dentes com restaurações classe II de cimento de ionômero de vidro. Lesões artificiais foram criadas na área de contato mesial de 30 molares permanentes, através de um sistema contendo ácido lático $\mathrm{com} \mathrm{pH} \mathrm{4,3.} \mathrm{Em} \mathrm{outros} 30$ molares, cavidades classe II padronizadas, foram preparadas na superfície disto-oclusal e foram restauradas com cermet, cimento de ionômero de vidro convencional/resina composta e amálgama. As superfícies restauradas foram colocadas ao lado das superfícies com lesão de cárie, simulando contato proximal e os dentes foram fixados em blocos de acrílico. Os corpos de prova foram mantidos em saliva artificial a $37^{\circ} \mathrm{C}, \mathrm{pH} 7,0$ por um período de 14 dias. As áreas de lesões cariosas foram quantificadas através de fotomicrografias. Os autores concluíram que o cimento de ionômero de vidro pode inibir cáries em superfícies dentárias interproximais adjacentes a superfícies restauradas com o cimento.

HATIBOVIC-KOFMAN; SULJAK; $\mathrm{KOCH}^{48}$, em 1997, investigaram a remineralização, in vitro, de lesões cariosas incipientes na presença de cimento de ionômero de vidro modificado por resina. Para tanto, 16 secções mesio-distais foram 
realizadas em molares decíduos extraídos, os quais possuíam lesões de manchas brancas proximais. As secções foram unidas a dentes plásticos restaurados com 0 cimento de ionômero de vidro modificado por resina (Vitremer), para simular a superfície de contato. As lesões foram fotografadas sob luz polarizada, inicialmente e após uma e duas semanas de exposição àsaliva artificial. Os autores observaram que $62 \%$ das secções mostraram uma redução quantitativa no tamanho do corpo da lesão e que a maior remineralização ocorreu durante a primeira semana de exposição à saliva artificial. Concluíram portanto que, a liberação de flúor de um cimento de ionômero de vidro tem potencial para aumentar a remineralização de lesões incipientes in vitro.

Em 1998, AGUILAR-GÁLVEZ², avaliou in vitro a liberação de flúor e atividade antimicrobiana de dois compômeros (Dyract e Compoglass). A liberação de flúor em água, foi medida diariamente por 14 dias. Paralelamente, por um período de 7 dias, em amostras igualmente padronizadas dos materiais, analisou-se a atividade antimicrobiana. Os resultados mostraram que os dois compômeros estudados liberaram quantidades mínimas de flúor durante todo o período de avaliação e nenhuma atividade antimicrobiana significante foi observada. Segundo a autora, a falta de atividade antimicrobiana estaria diretamente relacionada a pouca quantidade de flúor liberada pelos compômeros estudados.

Considerando a grande variedade comercial de materiais restauradores que liberam flúor e a diferença de composição existente entre eles, CARVALHO; CURY ${ }^{15}$, em 1998, avaliaram a capacidade de liberação de flúor de: um cimento de ionômero de vidro convencional (Chelon fil), um cimento de ionômero de vidro modificado por resina (Vitremer), duas resinas compostas modificadas por poliácidos (Variglass e Dyract) e uma resina composta contendo flúor em sua composição (Tetric). A liberação de flúor em água deionizada foi determinada durante 15 dias. Todos os materiais mostraram o mesmo padrão de liberação de flúor. As maiores médias de flúor, liberado dentro de cada material, foram encontradas no $1^{\underline{0}}$ dia, decrescendo bruscamente no $2^{\circ}$ e $3^{\circ}$ dias, e a quantidade de flúor liberado apresentou um decréscimo com o passar dos dias até atingir um nível quase constante. Existiram diferenças estatisticamente significantes entre a quantidade de 
flúor liberado por todos os materiais estudados, sendo que Chelon fil > Vitremer > Variglass $>$ Dyract $>$ Tetric. Segundo os autores, os resultados mostraram que a composição dos materiais restauradores influencia de maneira significativa sua liberação de flúor.

DIONYSOPOULOS et al. ${ }^{27}$, em 1998, avaliaram a progressão de cáries secundárias artificiais adjacentes a materiais restauradores, contendo ou não flúor, quando utilizados em raízes. Cavidades classe $\mathrm{V}$ foram preparadas nas superfícies vestibulares e linguais de 30 pré-molares extraídos. Os seis materiais utilizados foram: um cimento de ionômero de vidro convencional (Fuji), um cermet (Ketac Silver), uma resina composta contendo flúor (Tetric), uma resina composta sem flúor (Silux plus), um amálgama com alto conteúdo de cobre (Disperslloy) e um amálgama contendo flúor (Fluor-Alloy). Após 5 semanas de imersão em ácido gel com pH 4,5 os espécimes foram lavados abundantemente, seccionados longitudinalmente através das restaurações e examinados e fotografados em luz polarizada. A análise dos resultados mostrou que o cimento de ionômero de vidro convencional promoveu a maior proteção contra 0 ataque cariogênico, in vitro. $O$ grau de eficácia dos materiais restauradores foi o seguinte: Fuji $>$ Ketac Silver $>$ Tetric $>$ Silux plus $>$ Fluor-Alloy $>$ Dispersalloy. Os autores sugerem que em pacientes cárie-ativos, a restauração de cáries com cimento ionomérico pode ser de significante importância na prevenção de cáries secundárias ao redor de restaurações em raízes.

GROBLER; ROSSOUW; van WIK KOTZE ${ }^{42}$, em 1998, determinaram, in vitro, a liberação de flúor a curto e longo prazo de quatro cimentos de ionômero de vidro modificados por resina (Fuji II LC, Vitremer, Enforce e Advanced), de uma resina composta modificada por poliácidos (Dyract) e de um adesivo dentinário. Discos circulares de todos os materiais foram suspensos em água durante 300 dias, e a liberação de flúor, não cumulativa em 24 horas, foi determinada em períodos previamente determinados. Os autores enfatizaram que diferenças consideráveis entre os materiais foram encontradas a respeito da liberação de flúor. No primeiro dia, a liberação de flúor do Vitremer foi superior, enquanto que os materiais Dyract, Optibond e Enforce liberaram as menores quantidades. A partir do segundo dia, o cimento Advanced liberou mais flúor que o Vitremer, seguido do Fuji e dos demais 
materiais que continuaram liberando flúor em quantidades muito pequenas. Esta seqüência permaneceu a mesma até o final do experimento, e a maioria dos materiais, com exceção do cimento Enforce e do adesivo Optibond, continuou liberando flúor por todo o período.

Ainda em 1998, um estudo foi desenvolvido por PIMENTA et al. ${ }^{80}$, com o propósito de avaliar in vitro, algumas formas de prevenir ou reduzir a desmineralização no esmalte interno das paredes cavitárias adjacentes a restaurações de amálgama. Cavidades circulares foram preparadas em molares humanos e divididas em um grupo controle e 5 grupos experimentais, a saber: amálgama somente; verniz mais amálgama; gel flúor fosfato acidulado mais amálgama; amálgama adesivo com Panávia Ex; cimento de ionômero de vidro mais amálgama; controle (amálgama somente não submetido ao desafio cariogênico). Todos os espécimes do grupo experimental foram submetidos æ̀s ciclagens de $\mathrm{pH} e$ térmica e, em seguida, foram embutidos em resina acrílica e seccionados longitudinalmente através do centro das restaurações. A capacidade de inibir a desmineralização foi quantificada através dos testes de microdureza Knoop. Os autores concluíram que a utilização de um sistema adesivo, cimento de ionômero de vidro ou gel de flúor fosfato acidulado, sob restaurações de amálgama, pode interferir no desenvolvimento de cáries secundárias, uma vez que os valores de microdureza Knoop sugerem que estas técnicas oferecem resistência à desmineralização. Além disso, também observaram que o uso do verniz cavitário proporcionou maior perda mineral do que o amálgama colocado sozinho.

Um estudo foi conduzido por van DIJKEN; KIERI; CARLÉN ${ }^{26}$, em 1999, com o objetivo de avaliar in vivo, a durabilidade e o efeito cariostático de restaurações do tipo sanduíche-aberto, em cavidades classe II amplas, em pacientes adultos com baixa e alta atividade de cárie. Foram realizadas 274 restaurações e os materiais utilizados foram o cimento de ionômero de vidro modificado por resina Vitremer mais a resina composta Z-100. As restaurações foram avaliadas logo após a colocação e após 6, 12, 24 e 36 meses. Após 3 anos, 239 restaurações foram avaliadas. Apenas $5 \%$ das restaurações foram consideradas não aceitáveis. Fraturas de estrutura dentária foram observadas em 2,5\%. Dos pacientes avaliados, 
43\% eram considerados de alta atividade de cárie, mas somente uma restauração mostrou cárie secundária. Os autores concluíram que esta é uma técnica que pode ser indicada como alternativa ao amálgama, em cavidades amplas, principalmente em pacientes com alta atividade de cárie.

SMALES; $\mathrm{GAO}^{91}$, em 2000, avaliaram, in vitro, a capacidade de inibição da desmineralização do esmalte de cimentos de ionômero de vidro convencionais comercialmente indicados para restaurações atraumáticas. Cavidades padronizadas foram preparadas na região cervical de pré-molares humanos extraídos, foram restauradas com Fuji IX, Fuji IX GP, Ketac Molar e com uma resina composta modificada por poliácidos- Compoglass- que serviu como parâmetro para comparação. Os espécimes foram submetidos a termociclagem durante 300 ciclos nas temperaturas de $5^{\circ} \mathrm{C}$ e $55^{\circ} \mathrm{C}$, antes de serem colocados na solução desmineralizante por 4 semanas. Em seguida, foram seccionados através das restaurações e analisados em um microscópio de luz polarizada, sendo que a lesão foi medida utilizando um "software" de análise de imagens. A inibição da desmineralização do esmalte, imediatamente adjacente às margens das restaurações, foi mais freqüente para os cimentos ionoméricos do que para 0 Compoglass. Entretanto, a magnitude das zonas de inibição variou entre os diferentes materiais e locais. Os autores concluíram que materiais restauradores que liberam flúor oferecem algum grau de proteção, in vitro, ao esmalte adjacente contra a desmineralização.

A reabilitação de dentes decíduos, anteriores e posteriores, em paciente com cárie na primeira infância e extensas áreas de desmineralização, utilizando uma resina composta modificada por poliácidos, foi proposta por HOLANDA; BEZERRA; TOLEDO ${ }^{56}$, em 2000. As restaurações dentárias com o material Variglass foram realizadas em uma criança de três anos e com alta atividade de cárie. Paralelamente ao tratamento restaurador, realizou-se um trabalho educacional de prevenção da cárie (higiene bucal e dieta) para a criança e toda a família. As sessões de tratamento foram precedidas de controle de placa e reforço de técnica de escovação. Após a conclusão do tratamento, aplicações tópicas de verniz de flúor foram realizadas a cada 15 dias, durante dois meses. A manutenção 
preventiva foi proposta num intervalo de três meses. No controle de 27 meses, foi observada pequena perda de material e manchamento das restaurações, decorrentes da própria composição do material, entretanto, notou-se que as manchas brancas quase desapareceram por completo. Os autores destacaram que um conjunto de medidas preventivas foi responsável pelo resultado clínico do caso, salientando-se a importância do seguimento no processo educativo/preventivo da saúde do paciente, associado à indicação do material adequado æ̀̀ suas necessidades. Além disso, concluíram que o compômero demonstrou bom desempenho clínico após dois anos e nove meses de acompanhamento e que este material tem indicação para dentes decíduos de pacientes com atividade de cáries, em razão de suas propriedades adesivas, liberação de flúor, fácil manipulação e baixo índice de falhas.

CROLL; HELPIN; DONLY ${ }^{21}$, relataram, em 2000, uma experiência clínica após a utilização e acompanhamento, durante 8 anos, do cimento de ionômero de vidro modificado por resina Vitremer, em pré-escolares, escolares e adolescentes. Dentre as observações feitas pelos autores destacam-se: a) o material durou pelo menos oito anos quando utilizado em cavidades classe V ou III de dentes decíduos ou permanentes; b) fraturas em restaurações de classe II de dentes decíduos foram extremamente raras; c) nenhum paciente relatou sensibilidade pós-operatória tanto em dente decíduo quanto em permanente; d) cáries secundárias envolvendo as restaurações com o Vitremer foram raríssimas e usualmente estavam associadas a bolhas de ar. Os autores concluíram que o cimento de ionômero de vidro modificado por resina, Vitremer, mostrou ser durável e confiável para vários usos em Odontopediatria. Também enfatizaram que a adição de componentes resinosos minimizou três desvantagens críticas do cimento ionomérico: a baixa resistência à fratura, pobre resistência ao desgaste e extenso tempo de presa.

KOTSANOS ${ }^{62}$ estudou, em 2001, o efeito intra bucal de três materiais restauradores sobre o esmalte sadio sob condições cariogênicas. Fragmentos de esmalte bovino foram unidos a quatro corpos de prova hemi-esféricos de cada um dos três materiais testados (Ketac Molar, Vitremer, F-2000) e da resina composta 
utilizada como controle (Pertac II). Os espécimes foram inseridos na região vestibular de dentaduras inferiores, e os voluntários usaram a prótese ininterruptamente por 70 dias, sendo que 4 vezes ao dia a prótese era colocada em solução de sacarose a $3 \%$, durante 10 minutos. A microdureza superficial do esmalte foi avaliada, inicialmente, e, após a retirada dos espécimes das próteses. $A$ análise dos resultados mostrou que a proteção contra a desmineralização, em relação ao material controle, foi a seguinte: Vitremer $(82 \%)>$ Ketac Molar $(69 \%)>$ F-2000 (42\%). Depois, os fragmentos foram seccionados e analisados sob luz polarizada. $\mathrm{O}$ autor observou que as secções mostraram lesões subsuperficiais típicas, somente no grupo do Pertac II.

Uma avaliação retrospectiva do comportamento clínico do cimento de ionômero de vidro modificado por resina, Vitremer, foi publicada por CROLL et al. ${ }^{22}$, em 2001. Pacientes de uma mesma clínica particular, com no mínimo uma restauração feita com o Vitremer, em dente decíduo, há pelos menos três anos, foram chamados para avaliação. Todas as restaurações tinham sido realizadas pelo odontopediatra proprietário da clínica. Foram incluídas no estudo restaurações de classe I, II, III e V. Um total de 864 restaurações, de 306 pacientes, foi incluído no estudo. Os autores avaliaram as observações clínicas anotadas nos prontuários dos pacientes e utilizaram radiografias interproximais para investigação das restaurações de classe II. Os resultados mostraram um índice de sucesso total de $93 \%$, sendo que o índice de sucesso para restaurações de cavidades classe I foi de 92,6\%, para restaurações de cavidades classe II de 93,3\%, restaurações de cavidades classe III de $100 \%$ e restaurações de cavidades classe $V$ de $98,3 \%$.

Já em 2002, BURKE et al. ${ }^{11}$ fizeram uma revisão a respeito dos materiais derivados do cimento de ionômero convencional, os quais surgiram da tentativa de superar as propriedades críticas destes materiais. Segundo os autores, os cimentos de ionômero de vidro modificados por resina apresentam melhor resistência que os convencionais, enquanto conservaram a característica ideal de liberação de flúor e adesão confiável à estrutura dentária. Entretanto, a correta manipulação é necessária para que as características mecânicas sejam otimizadas. Com relação aos compômeros, relataram que são materiais de fácil manipulação e 
inserção, são mais resistentes, mais estéticos e menos solúveis que os ionômeros convencionais. Como principais desvantagens dos compômeros, citam que são materiais menos resistentes ao desgaste que as resinas compostas e liberam substancialmente menos flúor que os cimentos ionoméricos. Os autores ainda enfatizaram que, em se tratando de dentes decíduos, a resistência ao desgaste não é tão importante, mas a liberação de flúor pode ser benéfica. 


\section{PROPOSIÇÃO}

Neste estudo in vitro, foram confeccionadas restaurações em blocos de esmalte bovino hígido e com desmineralização prévia, utilizando quatro materiais restauradores estéticos: uma resina composta (Filtek Z-250 / 3M Dental Products St.Paul, MN, USA), uma resina composta modificada por poliácidos (Dyract AP/ Dentsply- Indústria e Comércio Ltda, Petrópolis-RJ), um cimento de ionômero de vidro modificado por resina (Vitremer / 3M Dental Products St Paul, MN, USA) e um cimento de ionômero de vidro convencional (Ketac Molar/ ESPE Dental AGGermany). Os espécimes foram submetidos a uma condição de alto desafio cariogênico, sob condições cíclicas de desmineralização e remineralização, com o seguinte objetivo:

Avaliar a ação cariostática de cada um dos materiais restauradores no que diz respeito à capacidade de minimizar a desmineralização do esmalte bovino (hígido ou com lesão de cárie incipiente artificial) adjacente às restaurações, considerando a profundidade em relação à superfície externa do esmalte e àdistância das paredes cavitárias / margem da restauração. 


\section{MATERIAL E MÉTODOS}

\subsection{Delineamento experimental}

Neste trabalho, o principal aspecto estudado foi o a ação cariostática de 4 materiais restauradores estéticos, divididos em 8 grupos, utilizando-se mais 4 grupos controle que não receberam tratamento restaurador para padronização dos resultados. Os espécimes foram constituídos de 144 fragmentos de dentes bovinos, 72 hígidos e 72 submetidos à desmineralização prévia, os quais foram divididos aleatoriamente entre os grupos. Todos os espécimes, com exceção aos pertencentes a dois dos grupos controle, foram submetidos a uma situação de severo desafio cariogênico. $O$ desenvolvimento de cárie dentária experimental em esmalte bovino hígido e desmineralizado, adjacente às restaurações, foi avaliado quantitativamente, através de testes de microdureza em secção longitudinal, nos quais dois aspectos foram considerados: profundidade em relação à superfície externa do esmalte e distância das paredes cavitárias/margem da restauração.

\subsection{Seleção e preparo dos dentes bovinos}

Para a realização do trabalho proposto, foram utilizados incisivos bovinos extraídos de gado de raça nelore com idade média de 36 meses, abatidos para consumo no Frigorífico Vangelio Mondelli Ltda, em Bauru, SP. Os dentes foram armazenados em solução de formol a 2\%, pH 7,0 6,105 (Laboratório da Disciplina de Bioquímica - FOB/USP) e mantidos em temperatura ambiente desde o momento das extrações. Após a remoção de debris, os dentes foram polidos com escova Robinson (KG Sorensen Ind. Com. Ltda -Barueri SP/ Brasil) em baixa rotação, associada a uma mistura de pedra pomes e água e, em seguida, lavados com água deionizada. Estes dentes foram submetidos a uma seleção inicial, na qual foram excluídos aqueles elementos que apresentaram falhas grosseiras, como trincas, fraturas, falhas na formação do esmalte ou ainda grande desgaste da superfície incisal.

As raízes dos dentes foram removidas (Figura 1a) através de seccionamento realizado sob refrigeração à água com disco diamantado flexível 
dupla face (KG Sorensen) em alta velocidade, montado em um torno Politriz (Fábtica Nacional de Motores Nevoni, 1/4 Hp, 20.000 rpm, Tipo F 56, São Paulo,SP). O remanescente pulpar coronário foi eliminado com auxílio de curetas. Em seguida, procedeu-se à separação da superfície vestibular e lingual da coroa (Fig. 1a). Para tanto, as coroas foram fixadas em discos de acrílico (Fig. 1b) com cera pegajosa (Kota Ind. e Com. Ltda., São Paulo, SP) e a separação das superfícies (Fig. 1c) foi realizada, sob refrigeração à água, em uma cortadeira elétrica (Labcut 1010- Extec Corp Enfield, CT, USA), na qual foi utilizado um disco diamantado dupla face (High Concentration Diamond Wafering Blade - Extec Corp.). As superfícies vestibulares continuaram sendo armazenadas na solução de formol já citada anteriormente.
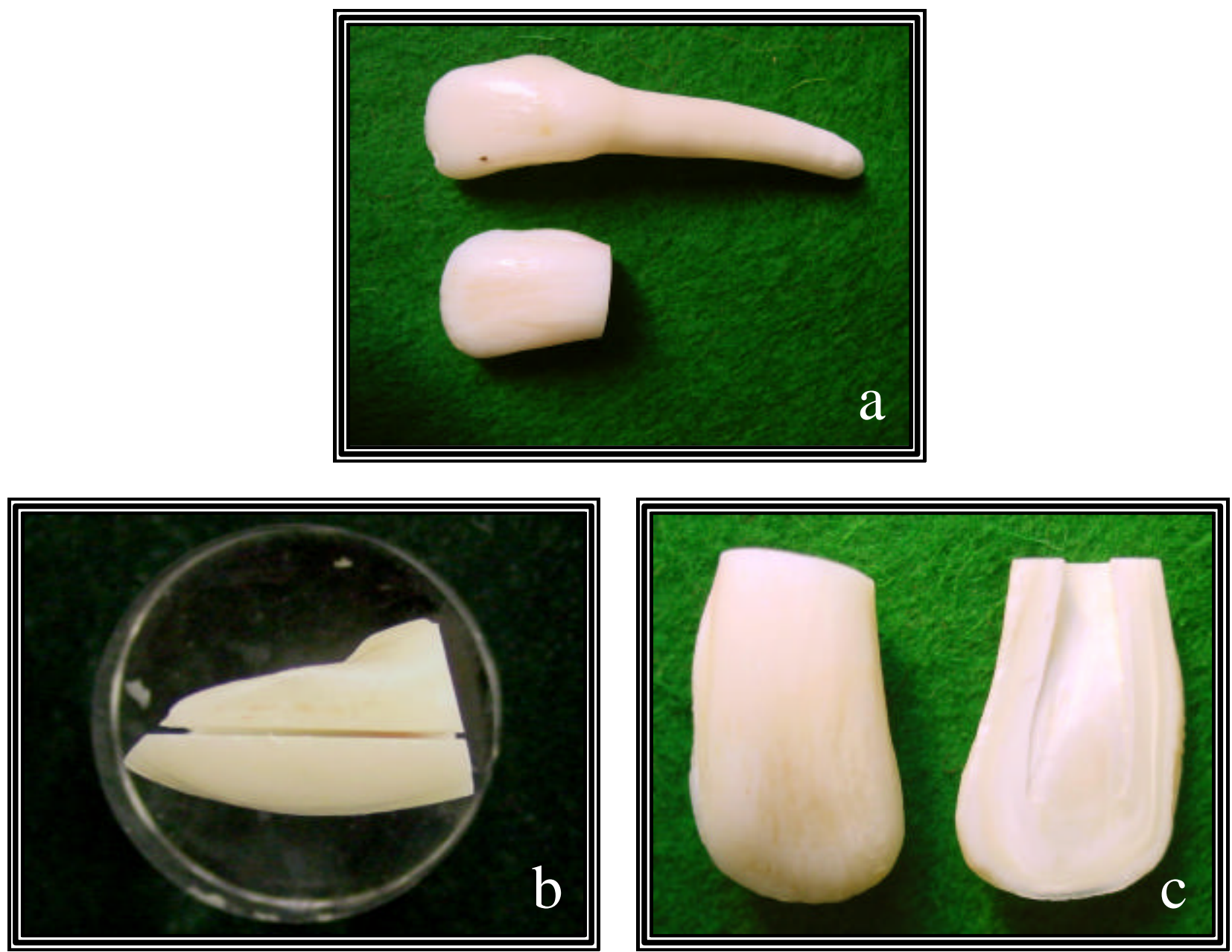

FIGURA 1- (a) Incisivo bovino antes e após a seccionamento corono-radicular. (b) Coroa fixada em disco de acrílico após secção vestíbulo-lingual. (c) Faces vestibular e lingual após separação. 
Para a obtenção de blocos de esmalte de $4 \mathrm{~mm} \times 4 \mathrm{~mm}$, utilizou-se o torno Politriz (Nevoni), onde foram acoplados 2 discos diamantados dupla face (KG Sorensen), com espaçador acrílico de $4 \mathrm{~mm}$, utilizando refrigeração à água. As superfícies vestibulares foram fixadas na placa de acrílico com cera pegajosa (Kota) e foram submetidas a dois cortes, paralelos entre si, no sentido longitudinal, e mais dois no sentido transversal, obtendo-se 1 bloco de dente da porção central da coroa (Figura 2).

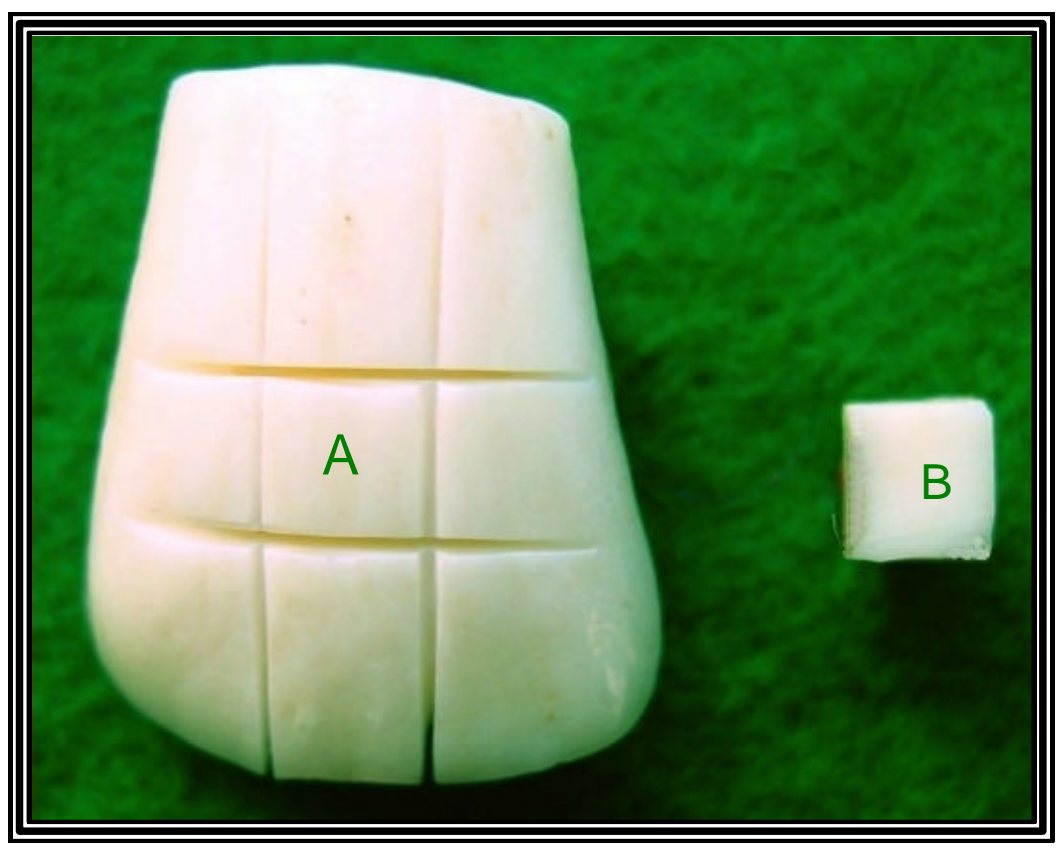

FIGURA 2- Seccionamento na área central (A) da face vestibular da coroa para obtenção do bloco de esmalte(B) .

Foi realizada uma segunda seleção dos fragmentos, na qual foram descartados elementos que apresentaram defeitos como trincas, fraturas, falhas na formação do esmalte (nesta etapa foram selecionados 360 blocos de esmalte). Os blocos foram armazenados em recipientes plásticos com tampa, contendo gaze embebida em água deionizada, àtemperatura de $\pm 4^{\circ} \mathrm{C}$. 


\subsection{Preparo dos blocos de dentes bovinos}

Inicialmente, foi realizada uma análise da microdureza superficial do esmalte para uma padronização dos fragmentos que fariam parte do experimento. Os blocos foram embutidos manualmente, quatro a quatro, em discos de resina epóxica Rede Fibra (Rede Fibra Com. de Produtos Fiberglass Ltda - SP), utilizandose para isso moldes de borracha de silicone azul (rede Fibra).

Com o objetivo de regularizar e planificar a superfície do esmalte dos blocos de dentes bovinos para os testes de microdureza superficial, os fragmentos foram polidos em uma Politriz DP-9a (Panambra Industrial e Técnica S.A Indústria Brasileira). A princípio, a seqüência de polimento foi a seguinte: a- lixa de silicone carbide granulação 320 (Extec Corp.,), durante 1 minuto, sob refrigeração à água, com rotação de 300 rpm; b- lixa de silicone carbide granulação 600 (Extec Corp.), por 1 minuto, sob refrigeração à água, com rotação de 300 rpm; c- lixa de silicone carbide granulação 1200 (Extec Corp.), durante 2 minutos, sob refrigeração àágua, com rotação de $600 \mathrm{rpm}$; d- disco de feltro (Extec Corp.) lubrificado com óleo mineral (Extec Corp.) e pasta de diamante de $3 \mu \mathrm{m}$ (Metadi II - Diamond Polishing Compund - Buehler Ltda, Lake Bluff, IL), por 2 minutos, com rotação de 600 rpm. Durante todos estes procedimentos, os blocos de esmalte foram mantidos em posição sobre as lixas, manualmente (Figura 3). A pressão digital exercida sobre 0 disco acrílico foi a mínima necessária para segurá-lo sobre o prato giratório, com o objetivo de eliminar a tendência de adquirir a mesma velocidade de rotação do prato que o disco passou a ter ${ }^{65}$.

Entre as lixas, os blocos passaram por uma limpeza em uma cuba ultra-sônica (Tempo Ultrassonic -T 14), contendo água deionizada por 2 minutos, com a finalidade de se eliminar qualquer resíduo proveniente da lixa. Após a utilização do feltro com o óleo mineral e pasta de diamante, os fragmentos passaram pela limpeza ultra-sônica em solução de detergente (Ultramet sonic clening solution - Buehler) diluída na proporção 1:20 em água deionizada e em seguida foram lavados com água deionizada. 


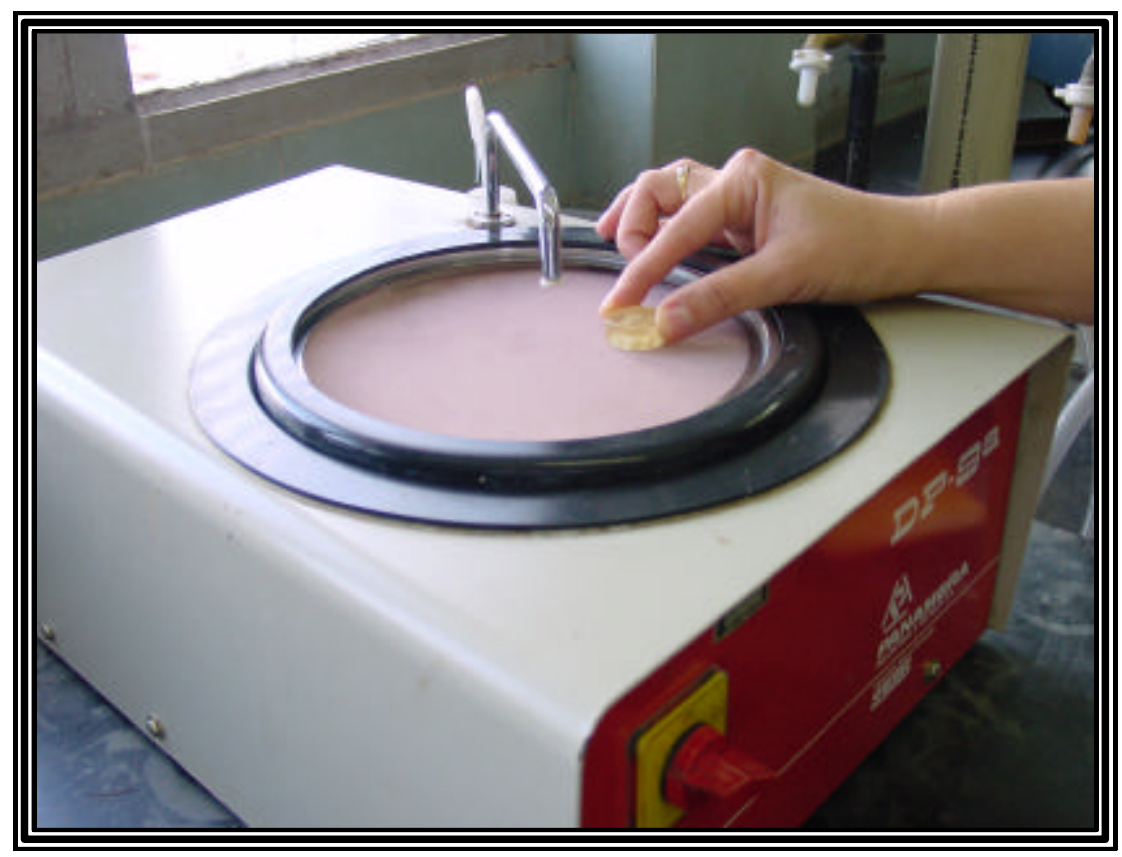

FIGURA 3 - Polimento manual dos blocos de esmalte

Após estes procedimentos, foi verificado a olho nu, se as superfícies de esmalte estavam planas, brilhantes e sem riscos, apresentando um brilho vítreo. Se isto fosse constatado, eram consideradas prontas para o processo de seleção dos blocos através do teste de microdureza superficial. O aparelho utilizado foi o microdurômetro M -Testor (Otto Wolpert - Werke, Alemanha) com penetrador tipo Knoop, carga estática de $50 \mathrm{~g}$, aplicada durante 7 segundos.

Foram realizadas 5 indentações no esmalte, separadas entre si por uma distância de $100 \mu \mathrm{m}$. O valor de microdureza Knoop do bloco foi obtido a partir da média das cinco indentações. Em seguida, obteve-se a média total da microdureza dos 360 blocos. Foram eliminados os blocos que tiveram média de microdureza inferior ou superior a $10 \%$ do valor da média total do grupo e/ou aqueles, cujo desvio padrão foi maior que $10 \%$ do valor da média de dureza do bloco $^{65}$. Desta forma, dos 360 blocos iniciais foram descartados 166 (46,1\%), restando 194 blocos (53,9\%).

Como os blocos estavam inseridos em discos de acrílico (4 blocos por disco), àmedida que iam sendo eliminados do estudo, eram recobertos por esmalte para unhas Colorama (CEIL - ComL. Exp. Ind. Ltda - SP / Brasil), na cor vermelha (Figura 4b). 
Dos 194 blocos, 84 foram selecionados aleatoriamente para compor o grupo hígido, sendo que para este grupo seriam necessários 72 blocos. Foram deixados 12 blocos sobressalentes para serem utilizados como reposição se houvesse perdas durante a etapa do preparo das cavidades.

Em seguida, realizou-se nos 110 blocos restantes um processo de desmineralização prévia com a finalidade de simular uma lesão cariosa incipiente. Os discos de resina contendo os blocos de esmalte foram imersos em uma solução indutora de cárie (Anexo 1), à base de ácido lático $0,05 \mathrm{M}, \mathrm{pH} 5,0,50 \%$ saturada com pó de esmalte bovino ${ }^{65}$, preparada no laboratório da disciplina de Bioquímica FOB/USP. O volume de solução usada para cada bloco foi determinado de acordo com a seguinte proporção: para cada $1,0 \mathrm{~mm}^{2}$ de esmalte exposto, foram utilizados 2,0 mL de solução desmineralizadora, ou seja, foram utilizados $32 \mathrm{~mL}$ da solução por bloco, pois a área de cada bloco era de $16 \mathrm{~mm}^{2}$. O processo de desmineralização foi conduzido a $37^{\circ} \mathrm{C} \pm 1$ por 16 horas, sendo que após as oito primeiras horas, a solução desmineralizante foi descartada e os espécimes foram colocados em solução nova por mais 8 horas.

Após a desmineralização, os blocos foram novamente submetidos aos ensaios de microdureza superficial, para uma nova seleção. $O$ teste foi realizado como descrito anteriormente e foram eliminados da amostra os blocos que apresentaram valor de microdureza maior que $50 \%$ do valor médio daquela correspondente ao esmalte hígido e/ou, cujo desvio padrão fosse maior que $10 \%$ da média dos valores de microdureza no bloco cariado ${ }^{65}$. Novamente, 84 blocos foram selecionados, sendo que destes 12 eram excedentes.

Todos os blocos de esmalte selecionados continuaram armazenados em recipientes plásticos fechados, sobre gazes embebidas em água deionizada.

\subsection{Preparo cavitário e restauração dos blocos de esmalte.}

Foram realizados manualmente preparos cavitários no centro dos blocos de esmalte, com ponta diamantada 1094 (KG Sorensen), em alta rotação, (Kavo do Brasil S.A. - Joinville SC / Brasil) sob refrigeração (Figura 4a), padronizando-se uma cavidade com $2 \mathrm{~mm}$ de diâmetro e $1,5 \mathrm{~mm}$ de profundidade 
(Figura 4b), a qual era conferida com o auxílio de uma sonda milimetrada. As brocas foram descartadas a cada dez preparos. O acabamento do preparo foi realizado em baixa rotação com uma broca de aço tungstênio vanádio n 45 (JOTA -AG - Ruthi Suíça) utilizando-se também dez brocas por preparo.
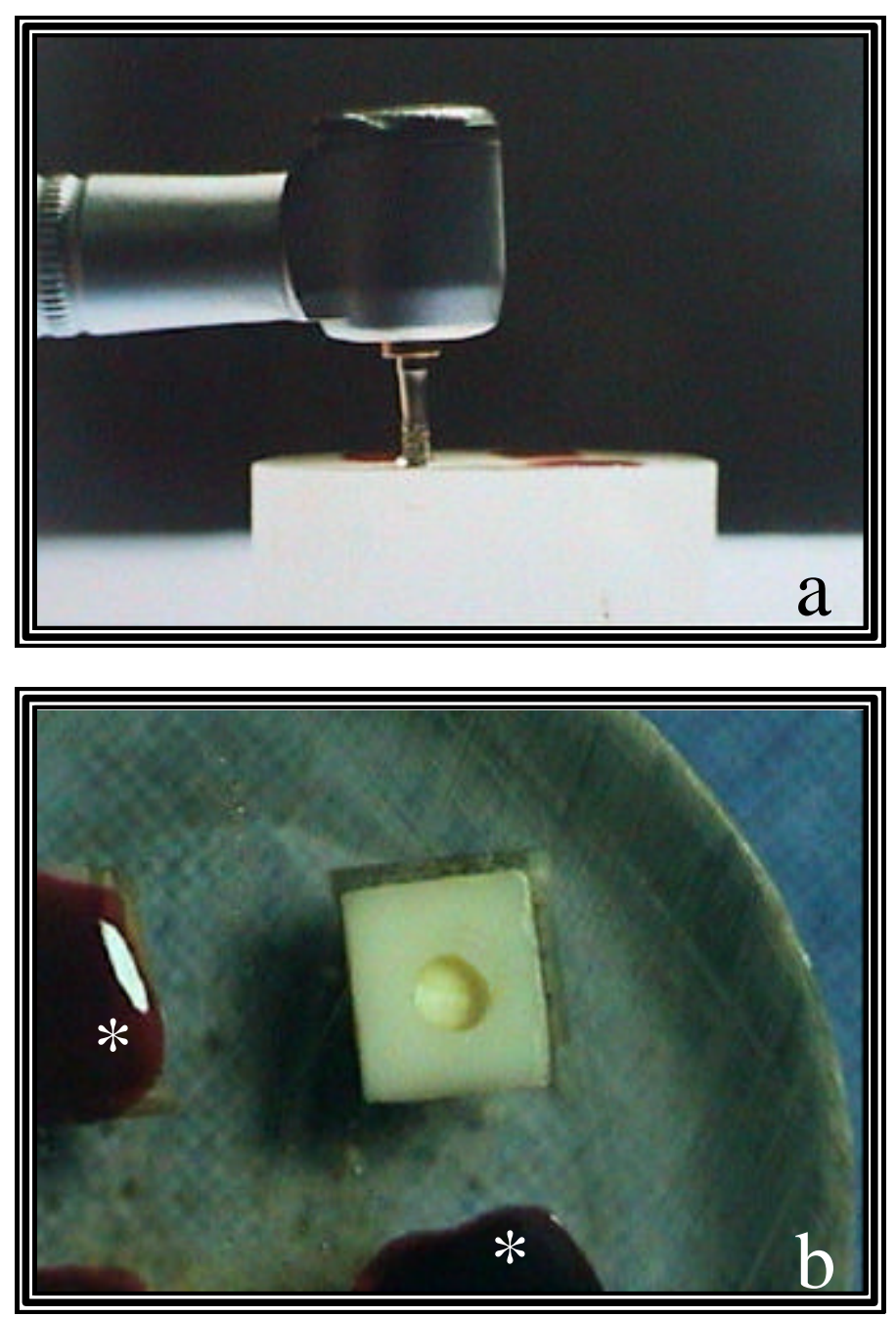

FIGURA 4 - (a) Ponta diamantada 1094 montada em caneta de alta rotação para realização do preparo cavitário. (b) Preparo cavitário realizado no centro do bloco . O * na cor branca, indica os blocos de dentes descartados, recobertos por esmalte vermelho.

Para confecção das restaurações, os 72 blocos com esmalte hígido(H) e os 72 blocos com esmalte desmineralizado (Des), foram divididos aleatoriamente em 12 grupos, sendo cada grupo constituído por 12 espécimes: 
> Grupo I: Controle H (S/D) - blocos de esmalte hígidos, sem preparo cavitário, que não foram submetidos ao desafio cariogênico.

> Grupo II: Controle H (C/D) - blocos de esmalte hígidos, sem preparo cavitário, submetidos àciclagem dinâmica de desmineralização e remineralização, ou seja, ao desafio cariogênico.

> Grupo III: Z-250 H - blocos de esmalte hígidos, restaurados com resina composta Filtek Z-250 (3M Dental Products St. Paul, MN, USA).

> Grupo IV: Dyract AP H - blocos de esmalte hígidos, restaurados com a resina composta modificada por poliácidos Dyract AP (Dentsply - Indústria e Comércio Ltda , Petrópolis-RJ).

> Grupo V: Vitremer H - blocos de esmalte hígidos, restaurados com o cimento de ionômero de vidro modificado por resina Vitremer (3M Dental Products St. Paul, MN, USA).

> Grupo VI: Ketac Molar H - blocos de esmalte hígidos, restaurados com o cimento de ionômero de vidro convencional Ketac Molar (ESPE Dental AG- Germany).

> GrupoVII: Controle Des (S/D) - blocos de esmalte desmineralizados, sem preparo cavitário, que não foram submetidos ao desafio cariogênico.

> Grupo VIII: Controle Des (C/D) - blocos de esmalte desmineralizados, sem preparo cavitário, submetidos à ciclagem dinâmica de desmineralização e remineralização, ou seja, ao desafio cariogênico.

> Grupo IX: Z-250 Des - blocos de esmalte desmineralizados, restaurados com resina composta Filtek Z-250.

> Grupo X: Dyract AP Des - blocos de esmalte desmineralizados, restaurados com a resina composta modificada por poliácidos Dyract $\mathrm{AP}$.

> Grupo XI: Vitremer Des - blocos de esmalte desmineralizados, restaurados com o cimento de ionômero de vidro modificado por resina Vitremer.

> Grupo XII: Ketac Molar Des - blocos de esmalte desmineralizados, restaurados com o cimento de ionômero de vidro convencional Ketac Molar. 
Os materiais foram manipulados de acordo com as instruções dos fabricantes, sendo que o número dos lotes dos materiais e técnicas restauradoras encontram-se no Anexo 2. Todos os procedimentos restauradores foram realizados em ambiente com temperatura controlada, em torno de $21 \pm 1^{\circ} \mathrm{C}$.

Os espécimes restaurados foram armazenados em recipientes plásticos, contendo gazes embebidas em água deionizada e foram mantidos em estufa (Modelo $002 \mathrm{CB}-F a n e m$ Ltda - São Paulo/Brasil) a $37^{\circ} \mathrm{C}+1^{\circ} \mathrm{C}$ a $37^{\circ} \mathrm{C}$ por 48 horas até a realização do acabamento e polimento com pontas abrasivas Enhance (Dentsplay - Brasil) e discos de lixa àbase de óxido de alumínio com granulação decrescente (Sof Lex - 3M do Brasil Ltda) e refrigeração àágua.

\subsection{Desafio Cariogênico}

Os grupos Controle H (S/D) e Controle Des (S/D) foram mantidos em água deionizada a $37+1^{\circ} \mathrm{C}$. Os demais grupos experimentais foram submetidos a um modelo dinâmico de desmineralização e remineralização, de acordo com a metodologia proposta por FEATHERSTONE ${ }^{34}$.

Os 12 espécimes de cada grupo foram colocados em recipientes plástico fechados, contendo $480 \mathrm{~mL}\left(40 \mathrm{~mL}\right.$ por bloco $\left.{ }^{34}\right)$ da solução desmineralizante, (2,0 mM de cálcio; 2,0 mM de fosfato; $75 \mathrm{mM}$ de acetato e azida $0,02 \%$ como conservante, em $\mathrm{pH} 4,3$ ) por 6 horas, em estufa a $37^{\circ} \mathrm{C} \pm 1^{\circ} \mathrm{C}$. Posteriormente, foram lavados em água deionizada e secos com papel absorvente para então serem colocados em $240 \mathrm{~mL}\left(20 \mathrm{~mL}\right.$ por bloco $\left.{ }^{34}\right)$ de solução remineralizante $(1,5 \mathrm{mM}$ de cálcio, $0,9 \mathrm{mM}$ de fosfato, $150 \mathrm{mM}$ de cloreto de potássio, $20 \mathrm{mM}$ de tampão tris e azida 0,02\% como conservante, em $\mathrm{pH} 7,0$ ) por 18 horas a $37^{\circ} \mathrm{C} \pm 1^{\circ} \mathrm{C}$. Ambas as soluções foram preparadas no laboratório da disciplina de Bioquímica FOB/USP. Foi realizado um total de 10 ciclos, conduzidos em 14 dias (5 ciclos consecutivos, 2 dias somente na solução para remineralização e, novamente, 5 ciclos e mais 2 dias para remineralização). Ainda de acordo com a metodologia de FEATHERSTONE (comunicação via e-mail), durante toda esta etapa experimental, utilizando as quantidades das soluções referidas acima, não foi necessário trocar as soluções por soluções novas. 
Após o término das ciclagens, os blocos dentários foram mantidos em estufa a $37^{\circ} \mathrm{C}+1^{\circ} \mathrm{C}$ em recipientes plásticos, contendo gaze embebida em água deionizada, até que os corpos de prova fossem preparados para a análise da microdureza em secção longitudinal.

\subsection{Obtenção das secções longitudinais}

Os blocos de esmalte foram removidos dos discos de resina, um a um, através do desgaste da resina ao redor do bloco, utilizando as mesmas pontas diamantadas usadas nos preparos cavitários. Em seguida, os blocos foram fixados individualmente com cera pegajosa em placas de acrílico e seccionados longitudinalmente, através do centro das restaurações. As secções foram realizadas sob refrigeração à água, em um torno Politriz (Nevoni), utilizando-se um disco de diamante dupla face (KG Sorensen) para cada 48 blocos.

As duas metades obtidas de cada fragmento de esmalte foram embutidas duas a duas, em resina termopolimerizável (Erios/S.P.), através da embutidora metalográfica. Foram utilizados para a confecção dos corpos de prova $5 \mathrm{~g}$ da resina em pó sendo que as metades foram fixadas em posição com cola adesiva (Super Bonder - Loctite Brasil Ltda- Itapevi - SP). Durante todo o processo, foi mantida uma pressão de $150 \mathrm{Kgf} / \mathrm{cm}^{2}$ e o tempo de aquecimento foi de 7 minutos e mais 7 minutos para resfriamento.

O polimento das superfícies foi realizado na Politriz Metalográfica APL4 (Arotec, Cotia-SP), por meio de um sistema de suporte acoplado (Figura 5a e 5b), de acordo com a seguinte seqüência de polimento: a- lixa de silicone carbide granulação 320 (Extec Corp.) , com 2 pesos, durante 1 minuto sob refrigeração à água; b- lixa de silicone carbide- granulação 600 (Extec Corp.), com 2 pesos, durante 1 minuto, sob refrigeração à água; c- lixa de silicone carbide- granulação 1200 (Extec Corp.), com 2 pesos, durante 2 minutos, sob refrigeração à água; ddisco de feltro (Extec Corp.) e spray de suspensão de diamante de $1 \mu \mathrm{m}$ (Buehler), com dois pesos, por 2 minutos, sem refrigeração, sendo que o spray era borrifado uma vez, no início do polimento, e mais uma vez, após o primeiro minuto. Entre as lixas, os blocos passaram por uma limpeza em cuba ultra-sônica (Branson 2210), 
contendo água deionizada, por 2 minutos, com a finalidade de se eliminar qualquer resíduo proveniente da lixa. Após a utilização do feltro com a suspensão de diamante, os fragmentos passaram pela limpeza ultra-sônica em solução de detergente (Ultramet sonic clening solution - Buehler), diluída na proporção 1:20 em água deionizada, e em seguida foram lavados com água deionizada.
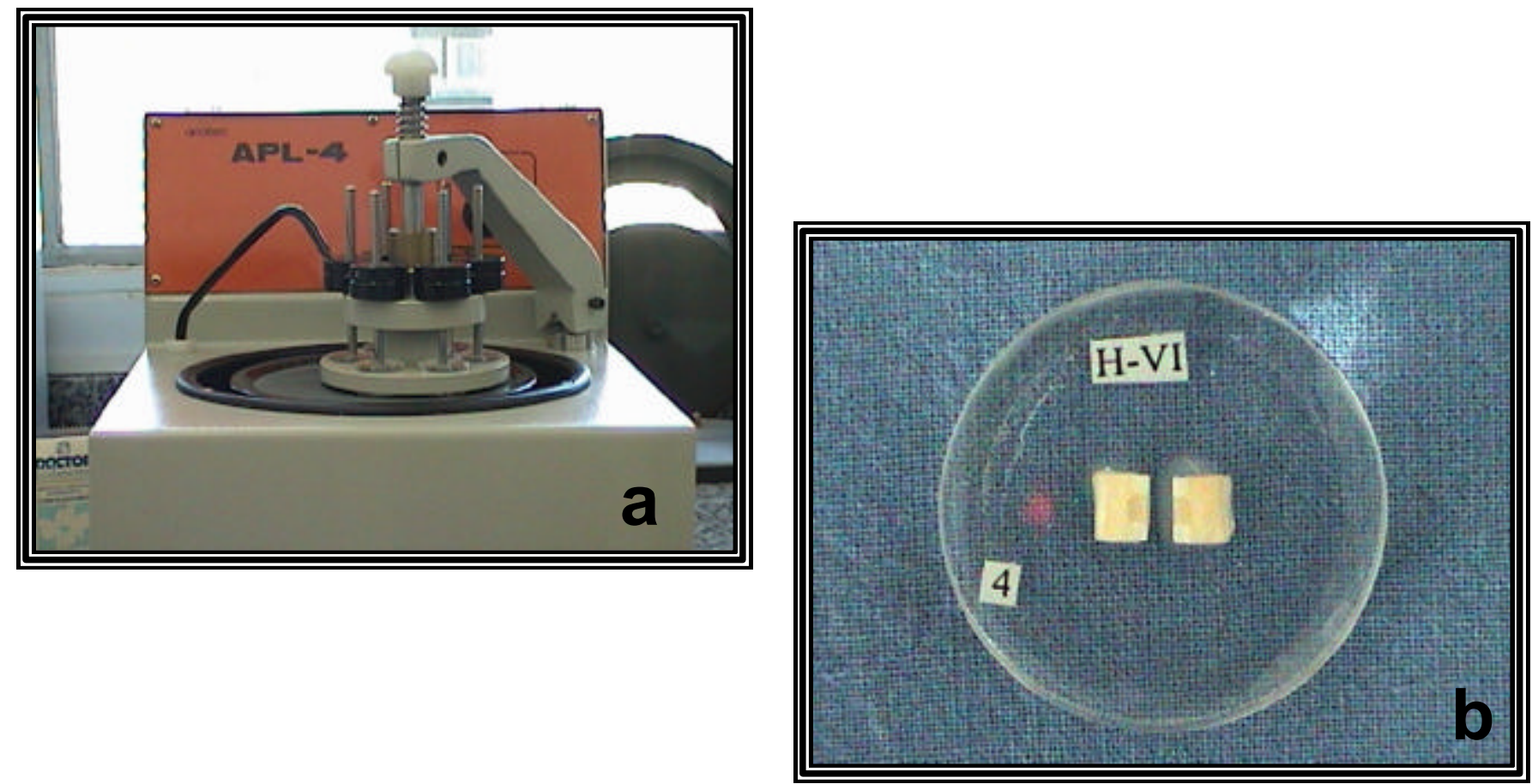

FIGURA 5 - (a) Polimento sendo realizado na politriz APL - 4 (Arotec)

Secções de um bloco de esmalte embutidas em disco de resina e polidas.

\subsection{Avaliação da Microdureza Longitudinal}

Para a análise da microdureza longitudinal de esmalte, foi utilizado o microdurômetro SHIMADZU MICRO HARDNESS TESTER HMV- 2000 (Shimadzu Corporation - Kyoto-Japan) com penetrador tipo Knoop, carga estática de $25 \mathrm{~g}$ aplicada durante 5 segundos, acoplado ao Software para análise de imagem CAMSWIN (NewAge Industries, USA) (Figuras 6a, 6b e 6c ). 

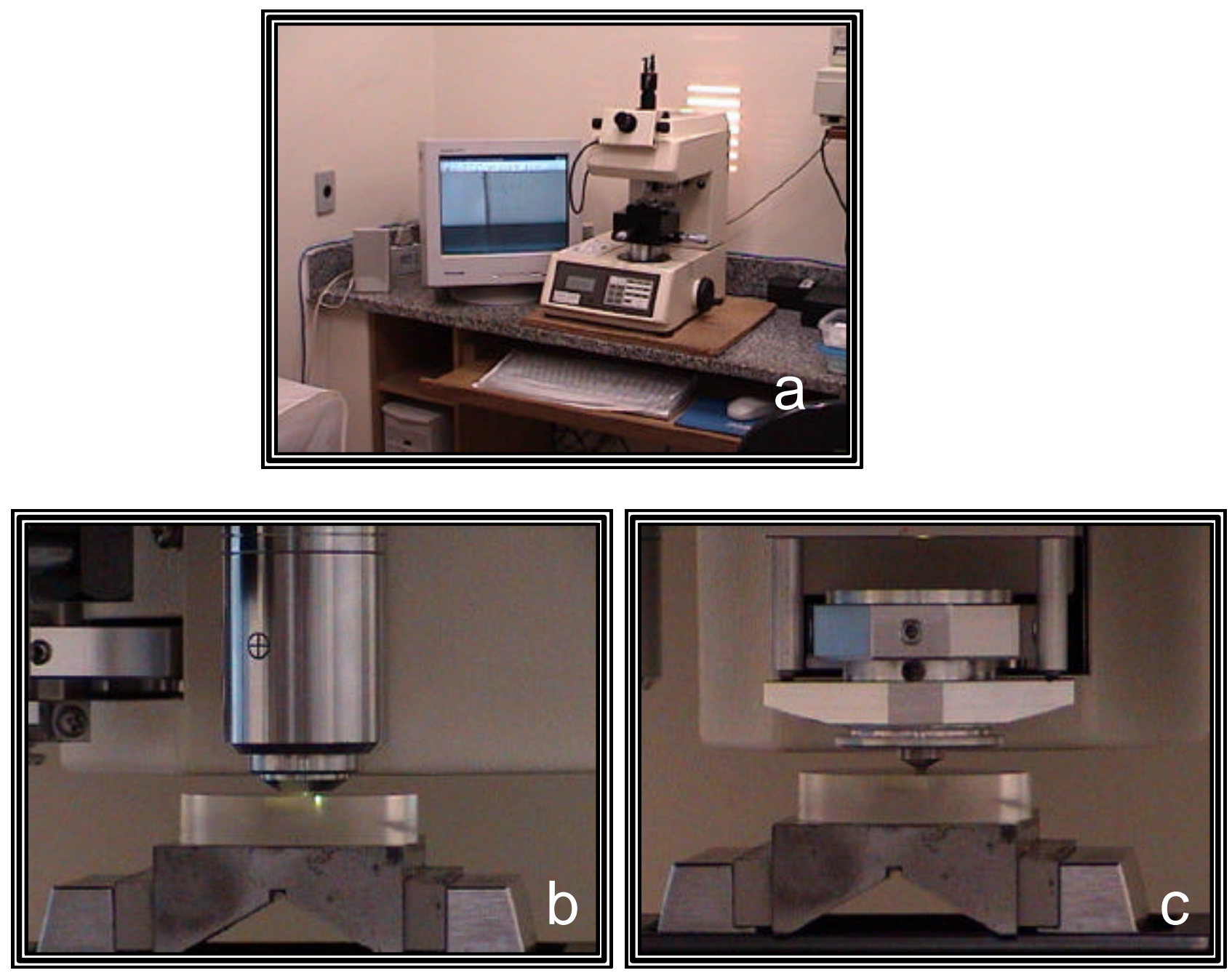

FIGURA 6 - (a) Microdurômetro SHIMADZU MICRO HARDNESS TESTER HMV- 2000.

(b) Corpo de prova em posição, com lente de aumento de 50x.

(c) Momento da aplicação do teste de microdureza - realização da impressão.

Foram realizadas 24 impressões com o longo eixo do diamante paralelo àsuperfície externa do esmalte, sendo que as primeiras foram localizadas a $30 \mu \mathrm{m}$ da mesma e as demais de 30 em $30 \mu \mathrm{m}$ até a profundidade de $240 \mu \mathrm{m}$.Com relação ao preparo cavitário, o limite esmalte/preparo foi considerado como zero e a partir daí foram realizadas impressões às distâncias de 50, 150 e $300 \mu \mathrm{m}$ (Figura 7).

As marcações foram realizadas nas duas metades de cada bloco (metade A e metade B), sendo que cada conjunto de 24 impressões foi realizado de cada lado das margens do preparo cavitário. Portanto, para cada bloco foram 4 conjuntos de 24 impressões, totalizando 96 por bloco (Figura 7). 

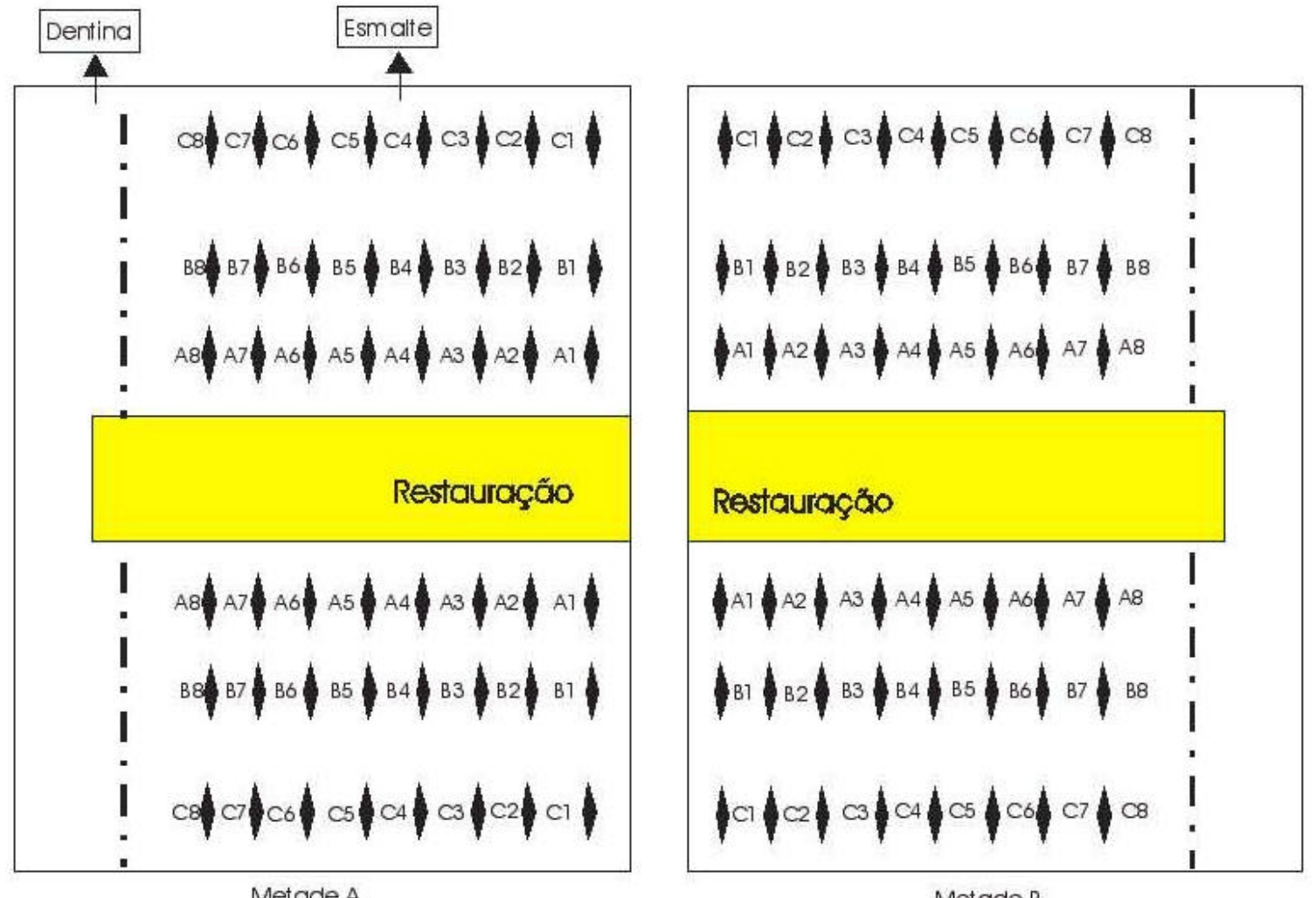

FIGURA 7: Pontos onde foram realizadas as impressões para avaliação da microdureza longitudinal.

$>$ Distância da parede cavitária (margem da restauração)
$A=50 \mu \mathrm{m}$
$\mathrm{B}=150 \mu \mathrm{m}$
$\mathrm{C}=300 \mu \mathrm{m}$

$>$ Profundidade em relação àsuperfície externa do esmalte

$$
\begin{array}{lll}
1=30 \mu \mathrm{m} & 2=60 \mu \mathrm{m} & 3=90 \mu \mathrm{m}
\end{array} \quad 4=120 \mu \mathrm{m} \quad 5=150 \mu \mathrm{m}
$$

Para os espécimes sem restaurações, a primeira seqüência de oito indentações foi realizada no centro de cada secção e a partir dela, mediu-se $100 \mu \mathrm{m}$ para realização da segunda fileira de oito marcas, a partir da qual mediu-se $150 \mu \mathrm{m}$ para realização das últimas impressões (Figura 8). Neste caso, para cada bloco foram realizadas 48 impressões. 


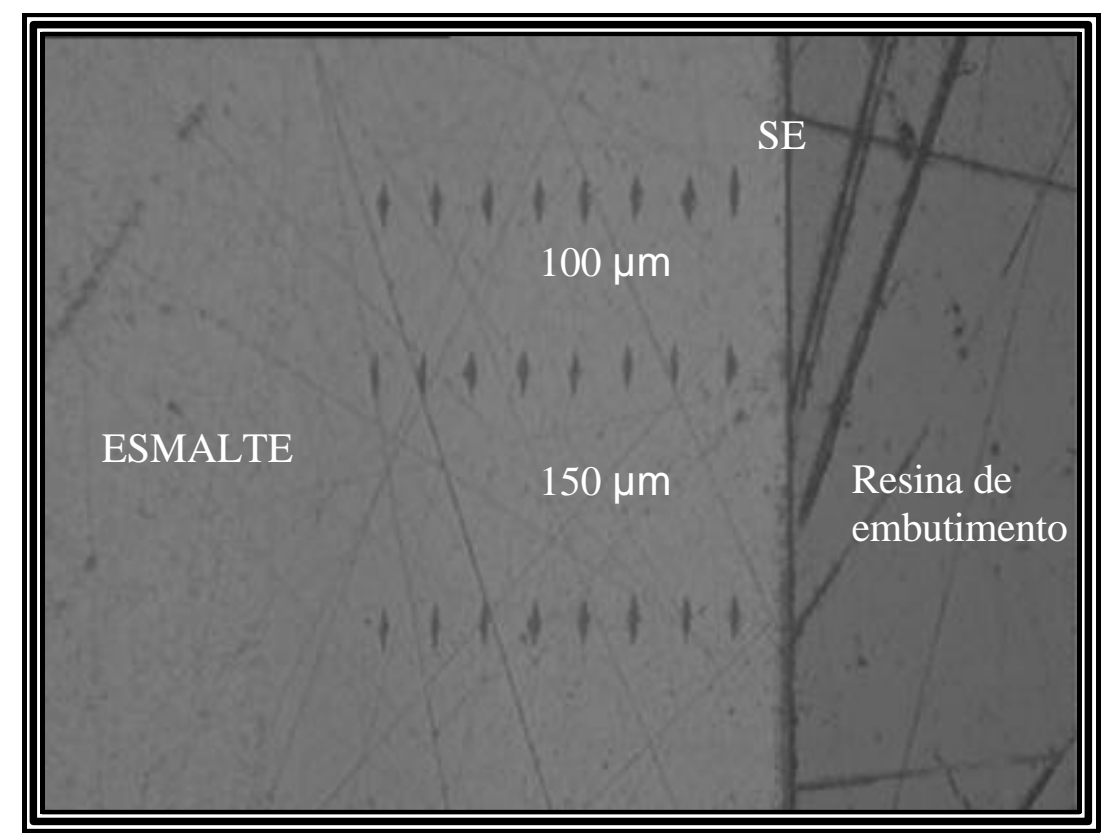

FIGURA 8 - Indentações realizadas no esmalte hígido, não submetido ao desafio cariogênico, sem preparo cavitário. Nas seqüências de 8 marcas, a distância a partir da superfície externa do esmalte (SE) e entre elas é de $30 \mu \mathrm{m}$.

Para alguns materiais, em determinadas profundidades e distâncias, a desmineralização do esmalte foi tanta, que tornou-se impossível quantificar o valor da dureza através do comprimento das indentações visto que as mesams excederam o campo de medição, ou ainda, houve uma erosão de porções mais superficiais do esmalte com perda de estrutura dentária. Neste último caso, os parâmetros adotados como início das marcações foram, para o esmalte hígido não restaurado, partes íntegras da superfície externa do esmalte (Figura 9) e no caso dos espécimes restaurados, a superfície externa da restauração serviu como base para o início das marcações (Figura 10). Nas distâncias e profundidades onde não foram possíveis realizar as marcações, pelos motivos explicados acima, o valor de microdureza Knoop foi considerado igual a 0 (zero). 


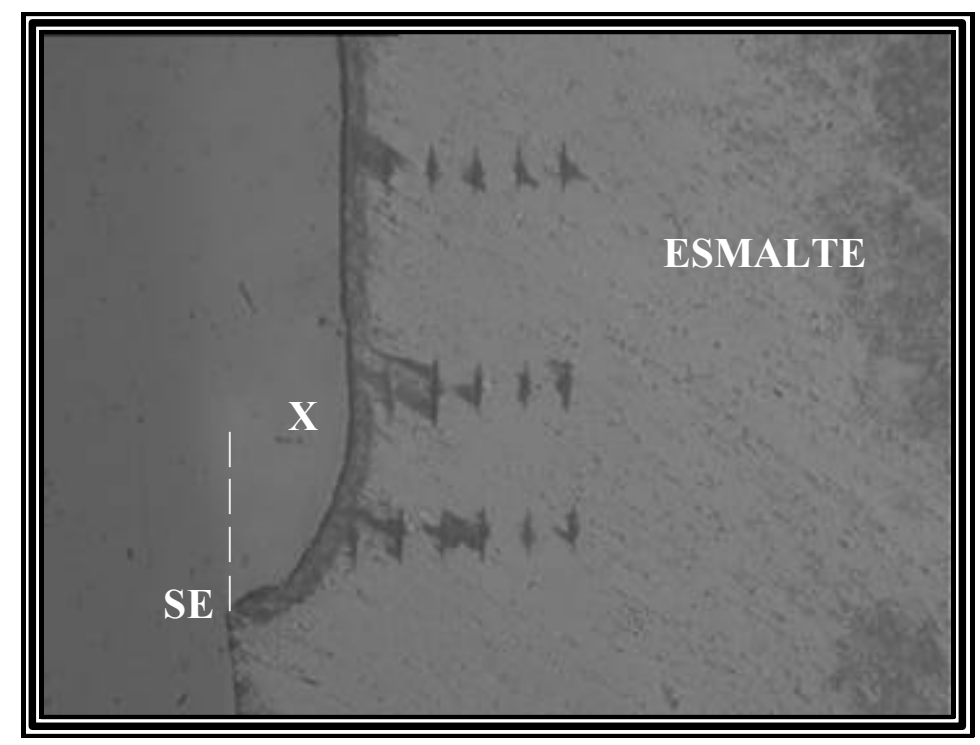

FIGURA 9 - Esmalte hígido, não restaurado, submetido ao desafio cariogênico./ $\mathrm{SE}=$ superfície externa do esmalte / $\mathrm{X}$ = área de erosão

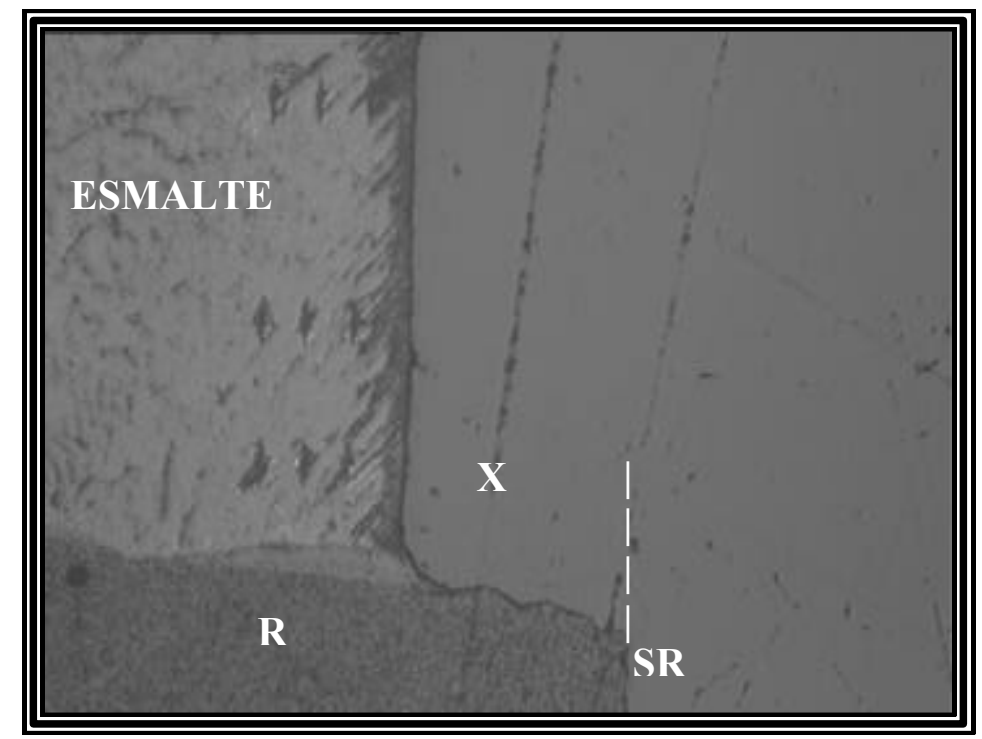

FIGURA 10 - Espécime com restauração $(\mathrm{R})$ / SR= superfície externa da restauração / $\mathrm{X}=$ área de erosão. 


\subsection{Análise Estatística}

Para a realização da análise dos resultados foram feitas as médias de todos os valores de microdureza encontrados para cada bloco. Os valores médios foram calculados para cada profundidade e distância. Sendo assim, cada bloco passou a ter 24 valores médios de microdureza e sobre estes valores foram aplicados os testes estatísticos.

A análise estatística constitui-se em estudar a variável dependente microdureza Knoop em esmalte bovino hígido e desmineralizado com os seguintes fatores de variação: tratamento restaurador, profundidade de desmineralização em relação à parede externa do esmalte e distância em relação ao preparo cavitário. Utilizou-se o método paramétrico de Análise de Variância (ANOVA) para verificar a interação entre as fontes de variação. Após constatação de diferenças significativas entre estes fatores, aplicou-se o Teste de Comparações Múltiplas de Tukey. O nível de significância mínimo adotado em todos os testes foi convencionalmente fixado em $5 \%$. O programa utilizado para as análises foi o "Statistic for Windows", versão 5.1 (StatSoft, Inc., Tulsa, OK, USA). 
5 RESULTADOS 


\section{RESULTADOS}

As médias e respectivos desvios-padrão obtidos pelos grupos experimentais durante os ensaios de microdureza para os diferentes tratamentos, profundidades em relação à superfície externa do esmalte e as distâncias das paredes cavitárias/ margem da restauração são mostrados nos Anexos 3, 4 e 5. Os valores médios da microdureza Knoop nas diferentes variáveis, podem ser melhor visualizados nos gráficos das Figuras 11,12 e 13.b

É importante destacar que, no tratamento controle correspondente ao esmalte desmineralizado que foi submetido ao desafio cariogênico (Controle Des C/D), não foi possível realizar os ensaios de microdureza Knoop. Isto porque houve um processo de erosão em toda superfície externa do esmalte, perdendo-se o parâmetro para demarcação das profundidades e aplicação dos testes. Este grupo foi, portanto, eliminado do estudo.

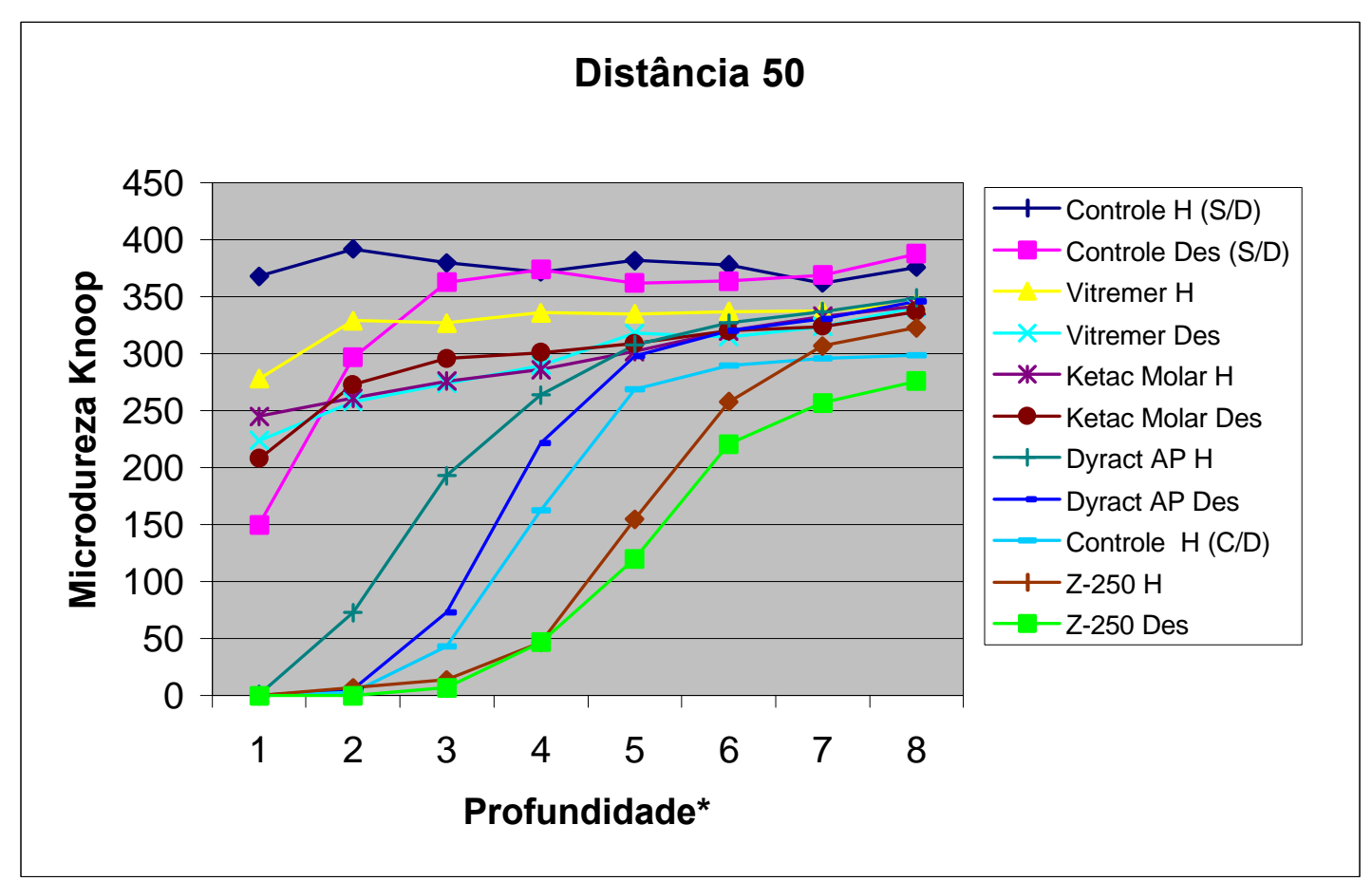

FIGURA 11 - Representação dos valores médios de microdureza Knoop para todos os tratamentos e profundidades, àdistância de $50 \mu \mathrm{m}$ das paredes cavitárias * $1=30 \mu \mathrm{m} \quad 2=60 \mu \mathrm{m} \quad 3=90 \mu \mathrm{m} \quad 4=120 \mu \mathrm{m} \quad 5=150 \mu \mathrm{m} \quad 6=180 \mu \mathrm{m} \quad 7=210 \mu \mathrm{m} \quad 8=240 \mu \mathrm{m}$ 


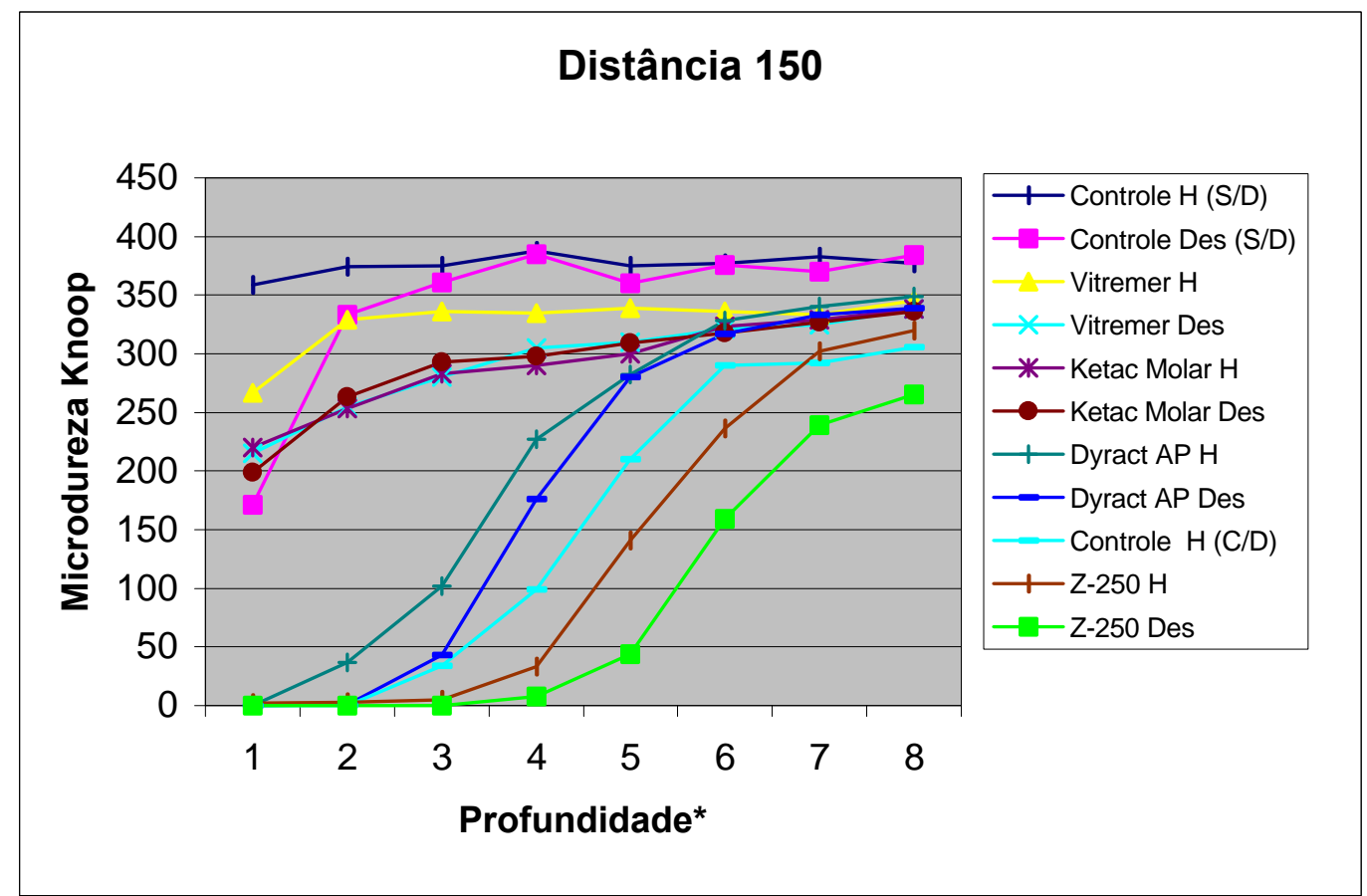

FIGURA 12 - Representação dos valores médios de microdureza Knoop para todos os tratamentos e profundidades, àdistância de $150 \mu \mathrm{m}$ das paredes cavitárias * $1=30 \mu \mathrm{m} \quad 2=60 \mu \mathrm{m} \quad 3=90 \mu \mathrm{m} \quad 4=120 \mu \mathrm{m} \quad 5=150 \mu \mathrm{m} \quad 6=180 \mu \mathrm{m} \quad 7=210 \mu \mathrm{m} \quad 8=240 \mu \mathrm{m}$

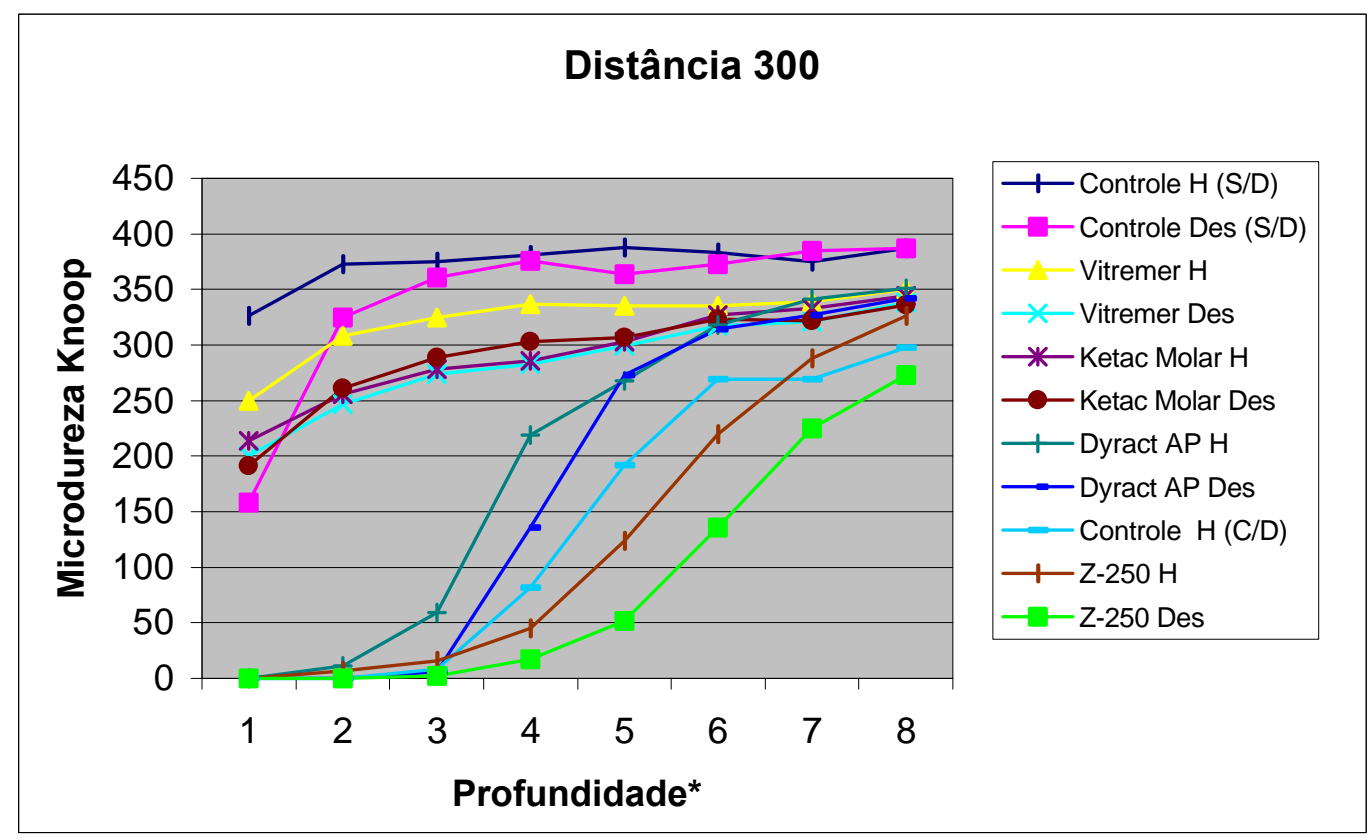

FIGURA 13 - Representação dos valores médios de microdureza Knoop para todos os tratamentos e profundidades, àdistância de $300 \mu \mathrm{m}$ das paredes cavitárias * $1=30 \mu \mathrm{m} \quad 2=60 \mu \mathrm{m} \quad 3=90 \mu \mathrm{m} \quad 4=120 \mu \mathrm{m} \quad 5=150 \mu \mathrm{m} \quad 6=180 \mu \mathrm{m} \quad 7=210 \mu \mathrm{m} \quad 8=240 \mu \mathrm{m}$ 
A Análise de Variância (ANOVA) dos valores médios de microdureza demonstrou efeito significativo para os três fatores isoladamente (tratamento, distância e profundidade), assim como para a interação entre eles $(p<0,0001)$ (Tabela 1).

Tabela 1- Resultado da Análise de Variância (ANOVA), comparando os fatores: tratamentos, as profundidades em relação à superfície externa do esmalte e distância das paredes cavitárias

\begin{tabular}{|c|c|c|c|c|c|c|}
\hline Efeito & $\begin{array}{c}\text { g.L } \\
\text { (Efeito) }\end{array}$ & $\begin{array}{l}\text { Quadrado } \\
\text { Médio } \\
\text { (Efeito) }\end{array}$ & $\begin{array}{l}\text { g.L. } \\
\text { (Erro) }\end{array}$ & $\begin{array}{l}\text { Quadrado } \\
\text { Médio } \\
\text { (Erro) }\end{array}$ & $\mathrm{F}$ & $P$ \\
\hline Tratamento & $10^{*}$ & $2491058,{ }^{*}$ & $121^{*}$ & $12351,51^{*}$ & $201,680^{*}$ & $0,000000^{*}$ \\
\hline Distância & $2^{*}$ & $44467,{ }^{*}$ & $242^{*}$ & $1132,98^{*}$ & $39,248^{*}$ & $0,000000^{*}$ \\
\hline Profundidade & $7^{*}$ & 2351637, * & $847^{*}$ & $1611,46^{*}$ & $1459,320^{*}$ & $0,000000^{*}$ \\
\hline Trat $x$ Dist & $20^{*}$ & $5993, *$ & $242^{*}$ & $1132,98^{*}$ & $5,289^{*}$ & $0,000000^{*}$ \\
\hline Trat $\times$ Prof & $70^{*}$ & $137610, *$ & $847^{*}$ & $1611,46^{*}$ & $85,395^{*}$ & $0,000000^{*}$ \\
\hline Dist $x$ Prof & $14^{*}$ & 3060 , & $1694^{*}$ & $472,67^{*}$ & $6,474^{*}$ & $0,000000^{*}$ \\
\hline Trat $\times$ Dist $\times$ Prof & $140^{*}$ & $1923,{ }^{*}$ & $1694^{*}$ & $472,67^{*}$ & $4,067^{*}$ & $0,000000^{*}$ \\
\hline
\end{tabular}

* Diferença estatisticamente significante

Após a detecção da significância estatística para a interação entre todos os fatores, aplicou-se o Teste de Comparações Múltiplas de Tukey entre os diferentes grupos, com a finalidade de se obter as diferenças mínimas significantes $(\alpha=5 \%)$.

Os valores médios de microdureza Knoop dos tratamentos assim como a comparação entre eles, dentro de cada profundidade e distância, estão representados nas Tabelas 2,3 e 4. 
Tabela 2 - Teste de Tukey para a comparação entre os tratamentos nas diferentes profundidades àdistância de $50 \mu \mathrm{m}$ das paredes cavitárias

\begin{tabular}{|c|c|c|c|c|c|c|c|c|}
\hline \multirow[b]{2}{*}{ Tratamento } & \multicolumn{7}{|c|}{ Profundidade ( $\mu \mathrm{m})$} & \multirow[b]{2}{*}{240} \\
\hline & 30 & 60 & 90 & 120 & 150 & 180 & 210 & \\
\hline Controle H (S/D) & 368,37 & 391,58 & $379,67^{*}$ & 372,21 & 381,54 & 377,62 & $362,17^{*} \bullet$ & $376,50 \bullet$ \\
\hline Controle Des (S/D) & 150,08 & $296,70^{*}$ & $362,62^{*}$ & 374,25 & $361,91^{*}$ & $363,96^{*}$ & $368,75 \bullet$ & 387,87 \\
\hline Vitremer $\mathbf{H}$ & 277,85 & 328,99 & $327,49^{*}$ & $336,09^{*}$ & $335,36^{\star *}$ & $337,44^{\star *}$ & $338,48^{\star \star} \bullet$ & $344,39^{*}$ \\
\hline Vitremer Des & $223,73^{*}$ & $257,70^{*}$ & 273,51 & $289,84^{*}$ & $318,35^{* *}$ & $315,25^{*}$ & $324,31^{* *}$ & $341,28^{*}$ \\
\hline Ketac Molar H & 244,85 & $261,35^{\star}$ & 275,75 & $285,62^{*}$ & $302,34^{*}$ & $320,24^{*}$ & $333,12^{* *}$ & $342,54^{*}$ \\
\hline Ketac Molar Des & $207,77^{*}$ & $272,75^{\star}$ & 296,14 & $300,67^{\star}$ & $308,58^{* *}$ & $320,11^{*}$ & $324,35^{\star \star}$ & $336,66^{*}$ \\
\hline Dyract AP H & 1,60 & 72,69 & 192,63 & $264,22^{*}$ & $307,69^{* *}$ & $326,90^{\star *}$ & $337,17^{\star \star} \bullet$ & $349,25^{\star} \bullet$ \\
\hline Dyract AP Des & 0,00 & 5,69 & $73,01^{*}$ & $221,84^{\star}$ & $298,23^{*}$ & $320,15^{\star}$ & $331,26^{* * *}$ & $345,83^{*} \bullet$ \\
\hline Controle H (C/D) & 0,00 & 3,21 & $43,25^{*}$ & 163,46 & 268,96 & $290,17^{*}$ & $296,33^{*}$ & $298,71^{*}$ \\
\hline Z-250 H & 0,00 & 7,02 & 14,11 & 46,99 & 154,65 & $258,44^{*}$ & $306,71^{* *}$ & $322,70^{*}$ \\
\hline Z-250 Des & 0,00 & 0,00 & 6,56 & 47,41 & 120,29 & 220,94 & 257,47 & $276,28^{*}$ \\
\hline
\end{tabular}

As barras verticais e os símbolos *** • denotam que não há diferença significante entre os grupos por eles demarcados quando comparados dentro da mesma coluna $(p<0,05)$. Valores em KHN

Tabela 3 - Teste de Tukey para a comparação entre os tratamentos nas diferentes profundidades àdistância de $150 \mu \mathrm{m}$ das paredes cavitárias

\begin{tabular}{|c|c|c|c|c|c|c|c|c|}
\hline \multirow[b]{2}{*}{ Tratamento } & \multicolumn{7}{|c|}{ Profundidade ( $\mu \mathrm{m})$} & \multirow[b]{2}{*}{240} \\
\hline & 30 & 60 & 90 & 120 & 150 & 180 & 210 & \\
\hline Controle H (S/D) & 358,71 & 373,96 & 375,50 & $387,58^{*}$ & $375,17^{*}$ & $376,96^{* *}$ & 383,25 & $376,83 \bullet$ \\
\hline Controle Des (S/D) & $171,46^{*}$ & 332,58 & 361,21 & $385,37^{*}$ & $359,67^{* *}$ & $375,83^{*}$ & $369,62 \bullet$ & 384,46 \\
\hline Vitremer $\mathbf{H}$ & 267,21 & 329,39 & $335,74^{*}$ & $334,75^{\star}$ & $338,92^{* *}$ & $336,43^{\star *}$ & $332,58^{*}$ & $345,08^{*}$ \\
\hline Vitremer Des & 214,74 & 254,97 & 279,93 & 304,77 & $309,88^{* *}$ & 320,67 & $324,53^{* *}$ & $338,31^{*}$ \\
\hline Ketac Molar H & 220,04 & 252,95 & $283,40^{*}$ & $290,12^{*}$ & $299,59^{*}$ & 323,19 & $329,27^{\star}$ & $338,23^{*}$ \\
\hline Ketac Molar Des & $198,78^{*}$ & 263,42 & $293,10^{*}$ & 298,25 & $308,69^{* *}$ & 317,85 & $326,99^{* *}$ & $335,88^{* *}$ \\
\hline Dyract AP H & 0,00 & 37,51 & 102,24 & $226,87^{*}$ & 281,82 & $328,55^{*}$ & $339,60 \bullet$ & $349,17^{*} \bullet$ \\
\hline Dyract AP Des & 0,00 & 1,69 & 43,26 & 176,46 & 280,00 & 317,26 & $332,58^{\star}$ & $339,43^{*}$ \\
\hline Controle H (C/D) & 0,00 & 0,00 & 34,29 & 99,29 & 209,67 & 289,58 & $292,50^{*}$ & $305,54^{*}$ \\
\hline Z-250 H & 2,20 & 3,57 & 5,05 & 33,09 & 141,11 & 235,86 & $302,25^{\star *}$ & 320,32 ** \\
\hline Z-250 Des & 0,00 & 0,00 & 0,00 & 7,79 & 44,16 & 159,31 & 238,88 & 264,58 \\
\hline
\end{tabular}

As barras verticais e os símbolos ** • denotam que não há diferença significante entre os grupos por eles demarcados quando comparados dentro da mesma coluna $(p<0,05)$. Valores em $\mathrm{KNH}$. 
Tabela 4 - Teste de Tukey para a comparação entre os tratamentos nas diferentes profundidades àdistância de $300 \mu \mathrm{m}$ das paredes cavitárias.

\begin{tabular}{|c|c|c|c|c|c|c|c|c|}
\hline \multirow[b]{2}{*}{ Tratamento } & \multicolumn{7}{|c|}{ Profundidade ( $\mu \mathrm{m})$} & \multirow[b]{2}{*}{240} \\
\hline & 30 & 60 & 90 & 120 & 150 & 180 & 210 & \\
\hline Controle H (S/D) & 362,41 & 372,79 & $375,29^{*}$ & $381,54^{*}$ & $388,17^{*}$ & $383,42^{*}$ & $375,00 \bullet *$ & 387,46 \\
\hline Controle Des (S/D) & 157,67 & 324,83 & $361,42^{*}$ & $375,92^{*}$ & $364,28^{* *}$ & $373,04^{*}$ & $384,58^{*}$ & 386,62 \\
\hline Vitremer $\mathbf{H}$ & 250,20 & 308,00 & $325,12^{\star}$ & $336,99^{*}$ & $334,68^{* *}$ & $335,13^{*}$ & $339,27 \bullet *$ & $350,30^{*}$ \\
\hline Vitremer Des & 199,64 & 247,48 & 274,04 & 283,39 & $298,88^{*}$ & $316,64^{*}$ & $320,58^{\star}$ & $337,67^{*}$ \\
\hline Ketac Molar H & 213,60 & 256,32 & 277,85 & 285,53 & $303,18^{*}$ & $327,03^{*}$ & $333,44^{*} \bullet$ & $344,01^{*}$ \\
\hline Ketac Molar Des & 191,24 & 260,60 & $289,37^{\star}$ & 302,84 & $307,37^{\star}$ & $323,49^{* *}$ & $322,08^{*}$ & $335,90^{*}$ \\
\hline Dyract AP H & 0,00 & 10,73 & 59,26 & 218,95 & 268,15 & $318,44^{* *}$ & $340,87 \bullet^{*}$ & $350,54^{*}$ \\
\hline Dyract AP Des & 0,00 & 0,00 & 5,75 & 135,53 & 272,68 & $314,21^{*}$ & $327,28^{*}$ & $342,04^{*}$ \\
\hline Controle H (C/D) & 0,00 & 0,00 & 8,12 & $82,29 *$ & 191,70 & $269,12^{\star}$ & $269,00^{*}$ & $298,37^{\star}$ \\
\hline Z-250 H & 0,00 & 7,02 & 16,27 & $45,35^{*}$ & 123,82 & 219,59 & $288,15^{\star}$ & $325,60^{*}$ \\
\hline Z-250 Des & 0,00 & 0,00 & 2,06 & 17,14 & 52,37 & 135,63 & $224,99^{*}$ & $272,56^{*}$ \\
\hline
\end{tabular}

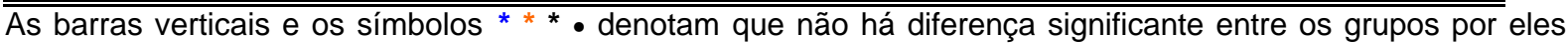
demarcados quando comparados dentro da mesma coluna $(p<0,05)$. Valores em KNH.

De uma maneira geral, observando-se a análise da comparação entre os diferentes tratamentos (Tabelas 2, 3 e 4), fica claro que o tratamento Controle $\mathrm{H}$ $(S / D)$ apresentou valores de microdureza Knoop elevados, sendo que nas profundidades de 30 e $60 \mu \mathrm{m}$ foi maior que todos os outros grupos, com diferença estatisticamente significante. Nas profundidades de 90 até $240 \mu \mathrm{m}$, não apresentou diferença significante em relação ao tratamento Controle Des (S/D).

$\mathrm{Na}$ profundidade de $30 \mu \mathrm{m}$, o tratamento Vitremer $\mathrm{H}$ apresentou valores de microdureza significativamente maiores que todos os outros grupos, com exceção do tratamento Controle $\mathrm{H}(\mathrm{S} / \mathrm{D})$. A partir da profundidade de $60 \mu \mathrm{m}$, não se observaram diferenças significativas entre os grupos Vitremer $\mathrm{H}$ e Controle Des, exceto na profundidade de $240 \mu \mathrm{m}$ e na profundidade de $210 \mu \mathrm{m}$ na distância de 150 $\mu \mathrm{m}$ das paredes cavitárias, onde este último grupo foi superior. No entanto, àmedida em que se aumentou a profundidade em relação àsuperfície externa do esmalte (a partir de $120 \mu \mathrm{m}$ ) houve uma tendência do grupo Vitremer $\mathrm{H}$ se igualar 
estatisticamente aos grupos Vitremer Des, Ketac Molar H e Des. A partir de $150 \mu \mathrm{m}$, não se observaram diferenças significantes entre os tratamentos Vitremer $\mathrm{H}$ e Des, Ketac Molar H e Des, Dyract AP H e Des.

Os tratamentos Vitremer Des, Ketac Molar $\mathrm{H}$ e Des tiveram comportamento estatisticamente semelhante entre si, com exceção da profundidade de $30 \mu \mathrm{m}$ e distância de $50 \mu \mathrm{m}$, onde o grupo Ketac Molar H obteve valor de microdureza superior. Estes tratamentos apresentaram valores intermediários de microdureza Knoop.

Os menores valores de microdureza, na profundidade de $30 \mu \mathrm{m}$ para as três distâmcias foram encontrados para os tratamentos Dyract AP H e Des, Controle $\mathrm{H}(\mathrm{C} / \mathrm{D}), \mathrm{Z}-250 \mathrm{H}$ e Des, sem diferenças estatisticamente significantes entre eles. Esta mesma observação foi feita para a profundidade de $60 \mu \mathrm{m}$, nas distâncias de 150 e $300 \mu \mathrm{m}$. Na distância de $50 \mu \mathrm{m}$ e profundidade de $60 \mu \mathrm{m}$, Dyract AP H foi superior aos tratamentos Dyract AP Des, Controle H (C/D), Z-250 H e Des, o mesmo ocorrendo para a profundidade de $90 \mu \mathrm{m}$ nas três distâncias.

Considerando-se a distância de $50 \mu \mathrm{m}$ das paredes cavitárias e profundidades de 180 a $240 \mu \mathrm{m}$, os tratamentos Controle H (C/D) e Z-250 H foram estatisticamente semelhantes, o mesmo sendo observado nas profundidades $210 \mathrm{e}$ $240 \mu \mathrm{m}$ (distância $150 \mu \mathrm{m}$ ) e profundidades de 120 a $240 \mu \mathrm{m}$ (distância $300 \mu \mathrm{m}$ ).

Na distância de $50 \mu \mathrm{m}$ das paredes cavitárias e profundidade de 120 a $180 \mu \mathrm{m}$ não houve diferença significante entre os tratamentos Z-250 H e Des. A partir de $210 \mu \mathrm{m}$, nesta mesma distância, o grupo Z-250 Des apresentou-se estatisticamente inferior a todos os outros tratamentos. Comportamento semelhante do grupo Z-250 Des também foi verificado nas profundidades de 150 a $240 \mu \mathrm{m}$ (distâncias de 150 e $300 \mu \mathrm{m}$ ) das paredes cavitárias.

As comparações entre as oito profundidades $(30,60,90,120,150$, 180, 210 e $240 \mu \mathrm{m}$ ) em relação aos diferentes tratamentos e distâncias encontramse nas Tabelas 5,6 e 7 . 
Tabela 5 - Comparação entre as profundidades nos diferentes tratamentos àdistância de 50 um da parede cavitária

\begin{tabular}{|c|c|c|c|c|c|c|c|c|c|c|c|}
\hline \multicolumn{12}{|c|}{ Tratamentos } \\
\hline $\begin{array}{l}\text { Profundidade } \\
\qquad(\mu \mathrm{m})\end{array}$ & $\begin{array}{c}\text { Ketac } \\
\text { Molar H }\end{array}$ & $\begin{array}{c}\text { Ketac } \\
\text { Molar Des }\end{array}$ & $\begin{array}{c}\text { Vitremer } \\
\mathrm{H}\end{array}$ & $\begin{array}{c}\text { Vitremer } \\
\text { Des }\end{array}$ & $\begin{array}{c}\text { Dyract AP } \\
\mathrm{H}\end{array}$ & $\begin{array}{c}\text { Dyract AP } \\
\text { Des }\end{array}$ & $\begin{array}{c}\text { Z-250 } \\
H\end{array}$ & $\begin{array}{c}\text { Z-250 } \\
\text { Des }\end{array}$ & $\begin{array}{c}\text { Controle H } \\
(\mathrm{S} / \mathrm{D})\end{array}$ & $\begin{array}{c}\text { Controle H } \\
(\mathrm{C} / \mathrm{D})\end{array}$ & $\begin{array}{c}\text { Controle } \\
\text { Des (S/D) }\end{array}$ \\
\hline 30 & 244,85 & 207,77 & 277,34 & 223,74 & 1,60 & $\overline{0,00}$ & 0,00 & 0,00 & 368,37 & 0,00 & 150,08 \\
\hline 60 & $261,35^{\star}$ & 272,75 & 328,99 & 257,70 & 72,69 & 5,69 & $7,02^{*}$ & 0,00 & 391,58 & 3,21 & 296,71 \\
\hline 90 & $275,75^{\star}$ & 296,14 & 327,49 & $273,51^{\prime}$ & 192,63 & 73,00 & $14,11^{*}$ & $6,56^{*}$ & 379,67 & 43,25 & 362,62 \\
\hline 120 & $285,62^{*}$ & 300,67 & 336,10 & $289,84^{*}$ & 264,23 & 221,85 & $46,99^{*}$ & $47,41^{*}$ & 372,21 & 163,46 & 374,25 \\
\hline 150 & $302,34^{*}$ & $308,58^{*}$ & 335,36 & 318,35 & 307,69 & 298,23 & 154,65 & 120,29 & 381,54 & 268,96 & 361,92 \\
\hline 180 & $320,24^{*}$ & $320,11^{*}$ & 337,44 & 315,25 & $326,90^{*}$ & $320,15^{\star}$ & 258,44 & 220,94 & 377,62 & 290,17 & 363,96 \\
\hline 210 & 333,12 & $324,35^{\star}$ & 338,48 & $324,31 \uparrow$ & $337,17^{*}$ & $331,26^{*}$ & 306,71 & $257,47 *$ & 362,17 & 296,33 & 369,75 \\
\hline 240 & 342,53 & 336,65 & 344,39 & $341,28^{*}$ & $349,26^{*}$ & $345,83^{*}$ & 322,70 & $276,28^{*}$ & 376,50 & 298,71 & 381,87 \\
\hline
\end{tabular}

As barras verticais e os símbolos * * denotam que não há diferença significante entre as profundidades por eles demarcados quando comparados dentro da mesma coluna $(p<0,05)$. Valores em KHN. 
Tabela 6 - Comparação entre as profundidades nos diferentes tratamentos àdistância de 150 um da parede cavitária

\begin{tabular}{|c|c|c|c|c|c|c|c|c|c|c|c|}
\hline \multicolumn{12}{|c|}{ Tratamentos } \\
\hline $\begin{array}{l}\text { Profundidade } \\
\qquad(\mu \mathrm{m})\end{array}$ & $\begin{array}{c}\text { Ketac } \\
\text { Molar H }\end{array}$ & $\begin{array}{c}\text { Ketac } \\
\text { Molar Des }\end{array}$ & $\begin{array}{c}\text { Vitremer } \\
\mathrm{H}\end{array}$ & $\begin{array}{c}\text { Vitremer } \\
\text { Des }\end{array}$ & $\begin{array}{c}\text { Dyract AP } \\
H\end{array}$ & $\begin{array}{c}\text { Dyract AP } \\
\text { Des }\end{array}$ & $\begin{array}{c}\text { Z-250 } \\
H\end{array}$ & $\begin{array}{l}\text { Z-250 } \\
\text { Des }\end{array}$ & $\begin{array}{c}\text { Controle H } \\
(S / D)\end{array}$ & $\begin{array}{c}\text { Controle H } \\
(\mathrm{C} / \mathrm{D})\end{array}$ & $\begin{array}{c}\text { Controle } \\
\text { Des (S/D) }\end{array}$ \\
\hline 30 & 220,04 & 198,78 & 267,21 & 214,73 & 0,00 & 0,00 & 2,20 & 0,00 & $358,71^{*}$ & $\overline{0,00}$ & 171,46 \\
\hline 60 & 252,95 & 263,42 & 329,39 & 254,97 & 37,51 & 1,69 & 3,57 & 0,00 & $373,96^{*}$ & 0,00 & $332,58^{*}$ \\
\hline 90 & 283,40 & 293,10 & 335,74 & 279,93 & 102,24 & 43,26 & 5,05 & 0,00 & $375,50^{*}$ & 34,29 & $361,21^{*}$ \\
\hline 120 & 290,12 & $304,77^{*}$ & 334,75 & 298,25 & 226,87 & 176,46 & 33,09 & 7,79 & 387,58 & $99,29^{*}$ & 385,37 \\
\hline 150 & 299,59 & $308,69 * *$ & 338,92 & $309,88^{\prime}$ & 281,82 & $280,00^{*}$ & 141,11 & 44,16 & $375,17^{*}$ & 209,67 & $359,67^{\star}$ \\
\hline 180 & 323,19 & $317,85^{\star *}$ & 336,43 & $320,67^{*}$ & 328,55 & $317,26^{*}$ & 235,86 & 159,31 & $375,83^{*}$ & 289,58 & 376,96 \\
\hline 210 & 329,27 & $326,99^{*}$ & 332,58 & $324,53^{\star}$ & 339,60 & 332,58 & 302,25 & 238,88 & $383,25^{\star}$ & 292,50 & 369,62 \\
\hline 240 & 338,23 & 335,88 & 345,08 & 338,31 & 349,17 & 339,44 & 320,32 & 264,58 & $376,83^{*}$ & 305,54 & 384,46 \\
\hline
\end{tabular}

As barras verticais e os símbolos * * denotam que não há diferença significante entre as profundidades por eles demarcados quando comparados dentro da mesma coluna $(p<0,05)$. Valores em KHN. 
Tabela 7 - Comparação entre as profundidades nos diferentes tratamentos àdistância de 300 um da parede cavitária

\begin{tabular}{|c|c|c|c|c|c|c|c|c|c|c|c|}
\hline \multicolumn{12}{|c|}{ Tratamentos } \\
\hline $\begin{array}{l}\text { Profundidade } \\
\qquad(\mu \mathrm{m})\end{array}$ & $\begin{array}{c}\text { Ketac } \\
\text { Molar H }\end{array}$ & $\begin{array}{c}\text { Ketac } \\
\text { Molar Des }\end{array}$ & $\begin{array}{c}\text { Vitremer } \\
\mathrm{H}\end{array}$ & $\begin{array}{c}\text { Vitremer } \\
\text { Des }\end{array}$ & $\begin{array}{c}\text { Dyract AP } \\
\mathrm{H}\end{array}$ & $\begin{array}{c}\text { Dyract AP } \\
\text { Des }\end{array}$ & $\begin{array}{c}\text { Z-250 } \\
H\end{array}$ & $\begin{array}{c}\text { Z-250 } \\
\text { Des }\end{array}$ & $\begin{array}{c}\text { Controle H } \\
(S / D)\end{array}$ & $\begin{array}{c}\text { Controle H } \\
(C / D)\end{array}$ & $\begin{array}{c}\text { Controle } \\
\text { Des (S/D) }\end{array}$ \\
\hline 30 & 213,60 & 191,24 & 250,20 & 199,64 & 0,00 & 0,00 & 0,00 & 0,00 & $362,42^{*}$ & 0,00 & 157,67 \\
\hline 60 & 256,32 & 260,60 & 308,08 & 247,49 & 10,73 & 0,00 & 7,02 & 0,00 & $372,79^{*}$ & 0,00 & 324,83 \\
\hline 90 & $277,85^{*}$ & 289,37 & $325,12^{\star}$ & $274,05^{\star}$ & 59,26 & $5,75^{1}$ & 16,27 & 2,06 & $375,29^{*}$ & 8,12 & 361,42 \\
\hline 120 & $285,53^{*}$ & $302,84^{*}$ & $336,99^{*}$ & $283,39^{\star}$ & 218,95 & 135,53 & 45,35 & $17,14^{*}$ & $381,54^{*}$ & 82,29 & 375,91 \\
\hline 150 & $303,18^{*}$ & $307,37^{*}$ & $334,69 *$ & $298,88 *$ & 268,15 & 272,68 & 123,82 & $52,37^{*}$ & 388,17 & $191,71^{*}$ & 364,29 \\
\hline 180 & $327,02^{*}$ & $323,49^{*}$ & $335,13^{*}$ & $316,64^{*}$ & 318,44 & 314,21 & 219,59 & 135,63 & $383,42^{*}$ & $260,12^{*}$ & 373,04 \\
\hline 210 & 333,44 & $322,08^{*}$ & $339,27^{*}$ & 320,58 & 340,87 & 327,28 & 288,15 & 224,98 & $375,00^{*}$ & 269,00 & 384,58 \\
\hline 240 & 344,01 & 335,90 & 350,30 & 337,67 & 350,54 & 342,04 & 325,60 & 272,56 & 387,46 & 298,37 & 386,62 \\
\hline
\end{tabular}

As barras verticais e os símbolos * * denotam que não há diferença significante entre as profundidades por eles demarcados quando comparados dentro da mesma coluna $(p<0,05)$. Valores em KHN 
Observando-se as Tabelas 5, 6 e 7, pode-se constatar que a medida em que se afastou da superfície externa do esmalte, houve uma tendência de aumento de microdureza Knoop para todos os tratamentos, nas três distâncias das paredes cavitárias. Isto significa que de modo geral, os menores valores de microdureza encontraram-se nas profundidades de $30 \mu \mathrm{m}$ e foram aumentando gradativamente até as profundidades de $240 \mu \mathrm{m}$. Este aumento foi mais notório para os tratamentos Ketac Molar H e Des, Vitremer Des, Dyract AP H e Des, Z-250 H e Des e Controle H (C/D) nas três distâncias e Vitremer $H$ (distância de300 $\mu \mathrm{m}$ ).

Nas profundidades de 60 a $240 \mu \mathrm{m}$ (distâncias de 50 e $150 \mu \mathrm{m}$ ) não houve diferenças significantes para o tratamento Vitremer $\mathrm{H}$, o mesmo ocorrendo para o tratamento Controle H (S/D) nas distâncias de 150 e $300 \mu \mathrm{m}$ das paredes cavitárias. Já na distância de $50 \mu \mathrm{m}$, para este mesmo tratamento não foram observadas diferenças estatisticamente significantes entre todos os níveis de profundidade. Para o tratamento Controle Des (S/D), a partir da profundidade de 90 $\mu \mathrm{m}$, os valores de microdureza foram estatisticamente semelhantes considerando-se as três distâncias.

As comparações entre as três distâncias das paredes cavitárias (50, 150 e $300 \mu \mathrm{m}$ ) em relação aos diferentes tratamentos e profundidades encontram-se nas Tabelas 8 a 18. 
Tabela 8 - Comparação entre as distâncias (50, 150 e $300 \mu \mathrm{m})$ nas diferentes profundidades no tratamento Ketac Molar H

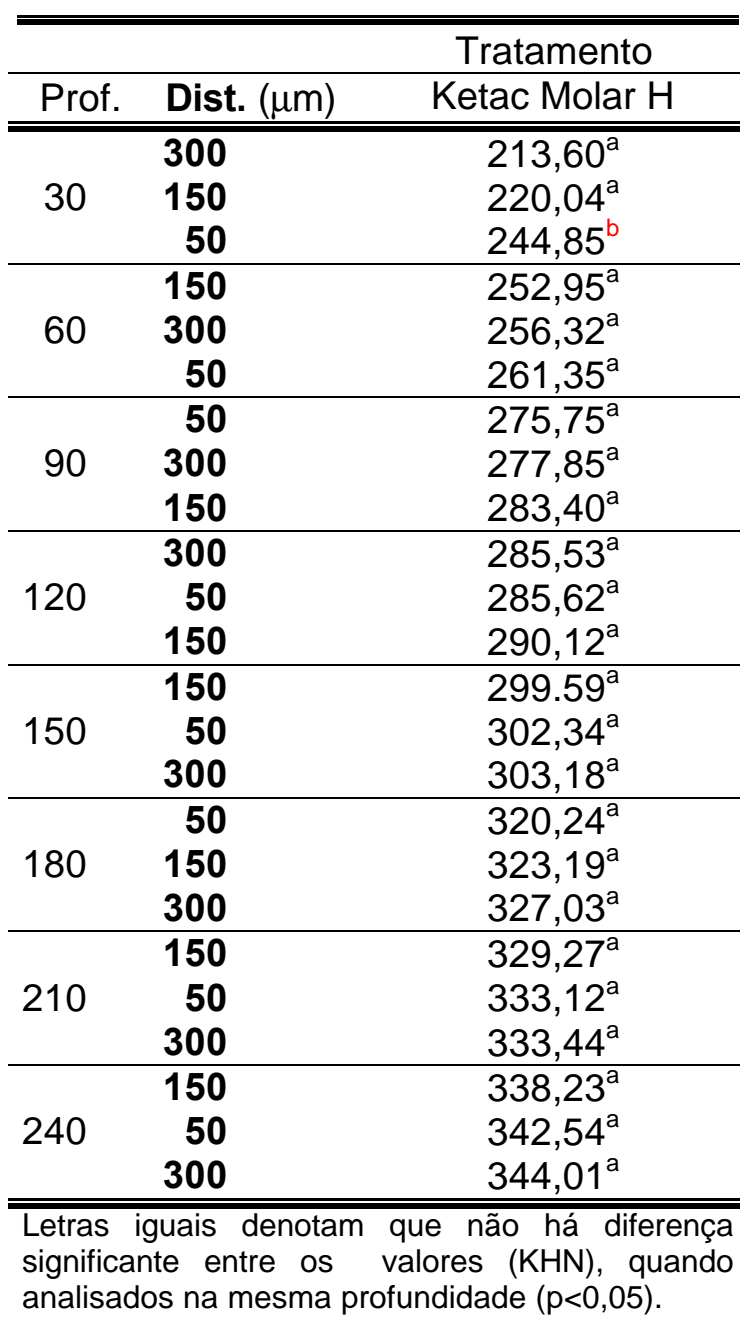

Tabela 9 - Comparação entre as distâncias (50, 150 e $300 \mu \mathrm{m})$ nas diferentes profundidades no tratamento Ketac Molar Des

\begin{tabular}{|c|c|c|}
\hline & & Tratamento \\
\hline Prof. & Dist. $(\mu \mathrm{m})$ & Ketac Molar Des \\
\hline \multirow{3}{*}{30} & 300 & $19191,24^{a}$ \\
\hline & 150 & $198,78^{a}$ \\
\hline & 50 & $207,77^{b}$ \\
\hline \multirow{3}{*}{60} & 150 & $260.60^{a}$ \\
\hline & 300 & $263,42^{a}$ \\
\hline & 50 & $272,75^{a}$ \\
\hline \multirow{3}{*}{90} & 300 & $289,37^{a}$ \\
\hline & 150 & $293.10^{a}$ \\
\hline & 50 & $296,14^{\mathrm{a}}$ \\
\hline \multirow{3}{*}{120} & 50 & $300,67^{a}$ \\
\hline & 300 & $30284^{a}$ \\
\hline & 150 & $304.77^{a}$ \\
\hline \multirow{3}{*}{150} & 300 & $307.37^{a}$ \\
\hline & 50 & $308,58^{a}$ \\
\hline & 150 & $308,69^{a}$ \\
\hline \multirow{3}{*}{180} & 150 & $317,85^{\mathrm{a}}$ \\
\hline & 50 & $320.11^{a}$ \\
\hline & 300 & $323,49^{a}$ \\
\hline \multirow{3}{*}{210} & 300 & $322,10^{\mathrm{a}}$ \\
\hline & 50 & $324.35^{\mathrm{a}}$ \\
\hline & 150 & $326.99^{a}$ \\
\hline \multirow{3}{*}{240} & 150 & $335,88^{\mathrm{a}}$ \\
\hline & 300 & $335,90^{\mathrm{a}}$ \\
\hline & 50 & $336,65^{a}$ \\
\hline & & iN), \\
\hline
\end{tabular}

Tabela 10 - Comparação entre as distâncias (50, 150 e $300 \mu \mathrm{m})$ nas diferentes profundidades no tratamento Vitremer $\mathrm{H}$

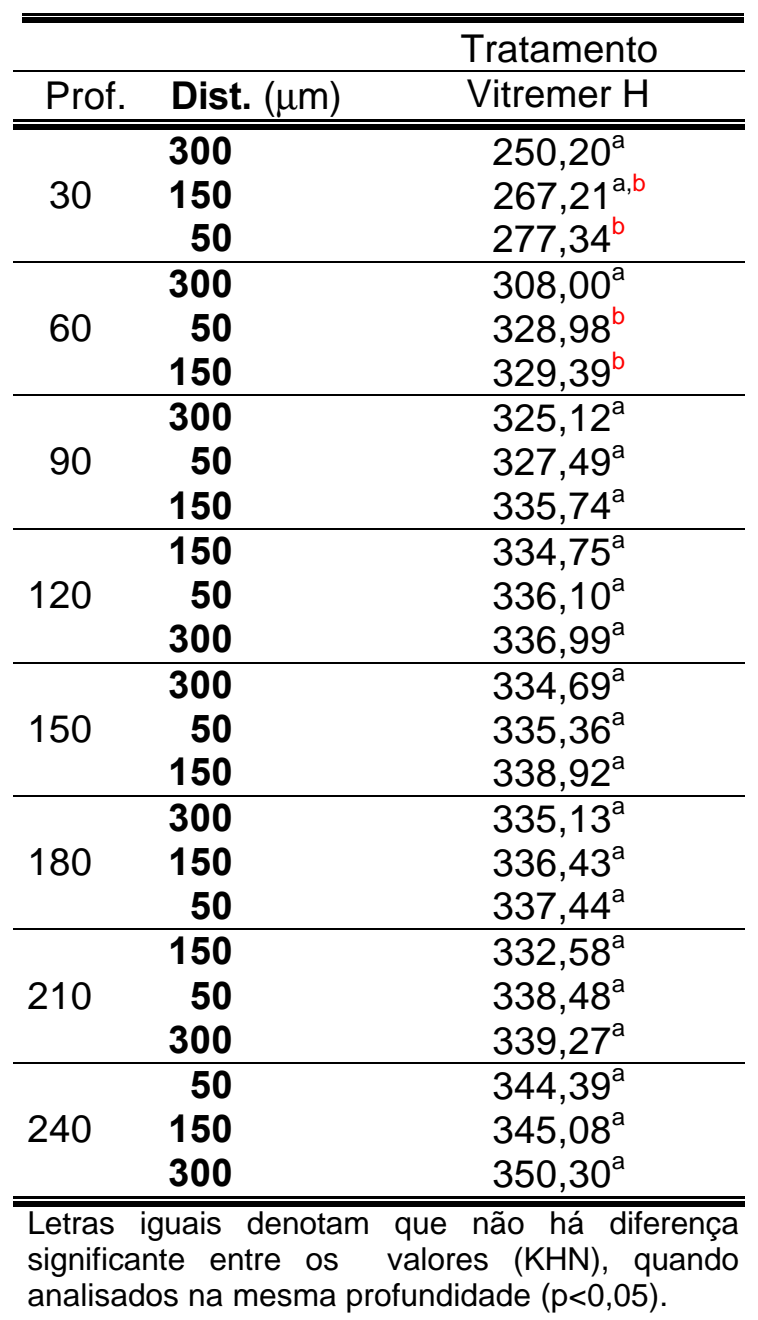


Tabela 11 - Comparação entre as distâncias (50, 150 e $300 \mu \mathrm{m})$ nas diferentes profundidades no tratamento Vitremer Des

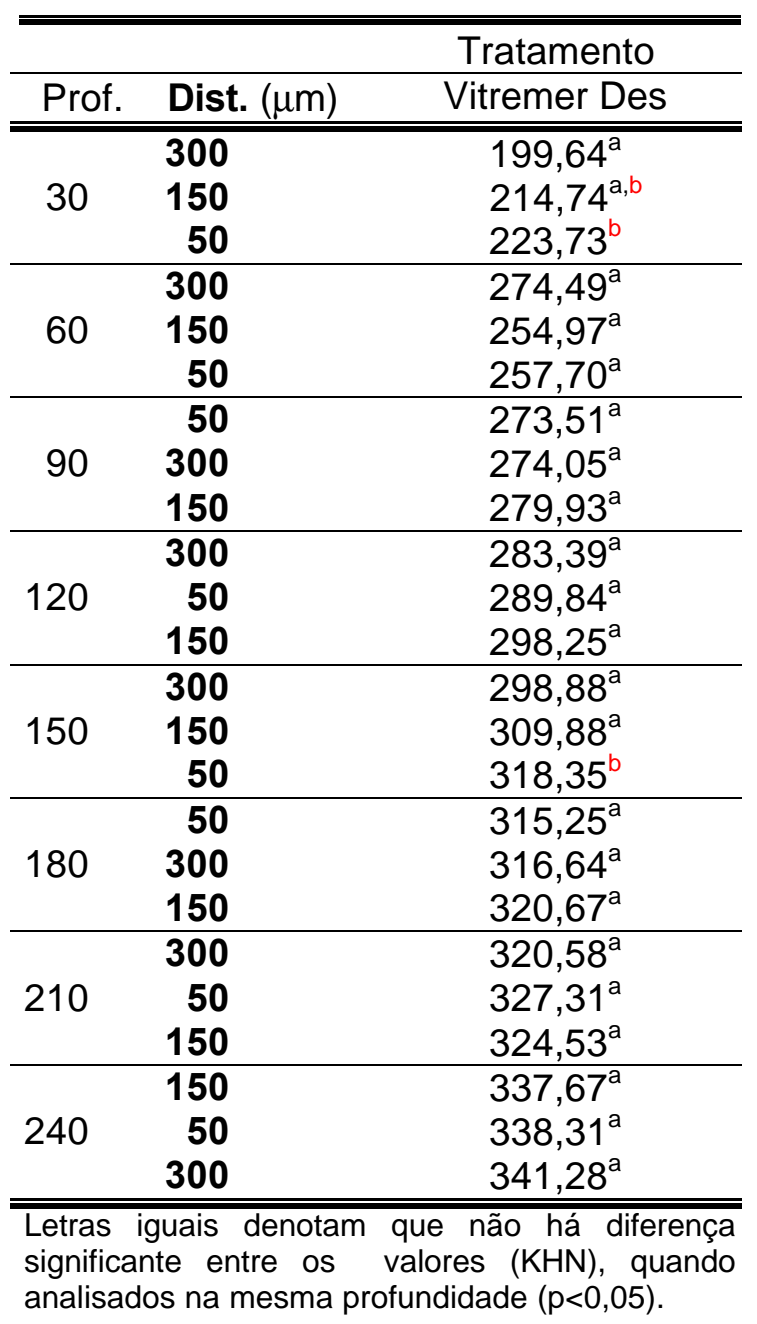

Tabela 12 - Comparação entre as distâncias (50, 150 e $300 \mu \mathrm{m})$ nas diferentes profundidades no tratamento Dyract AP H

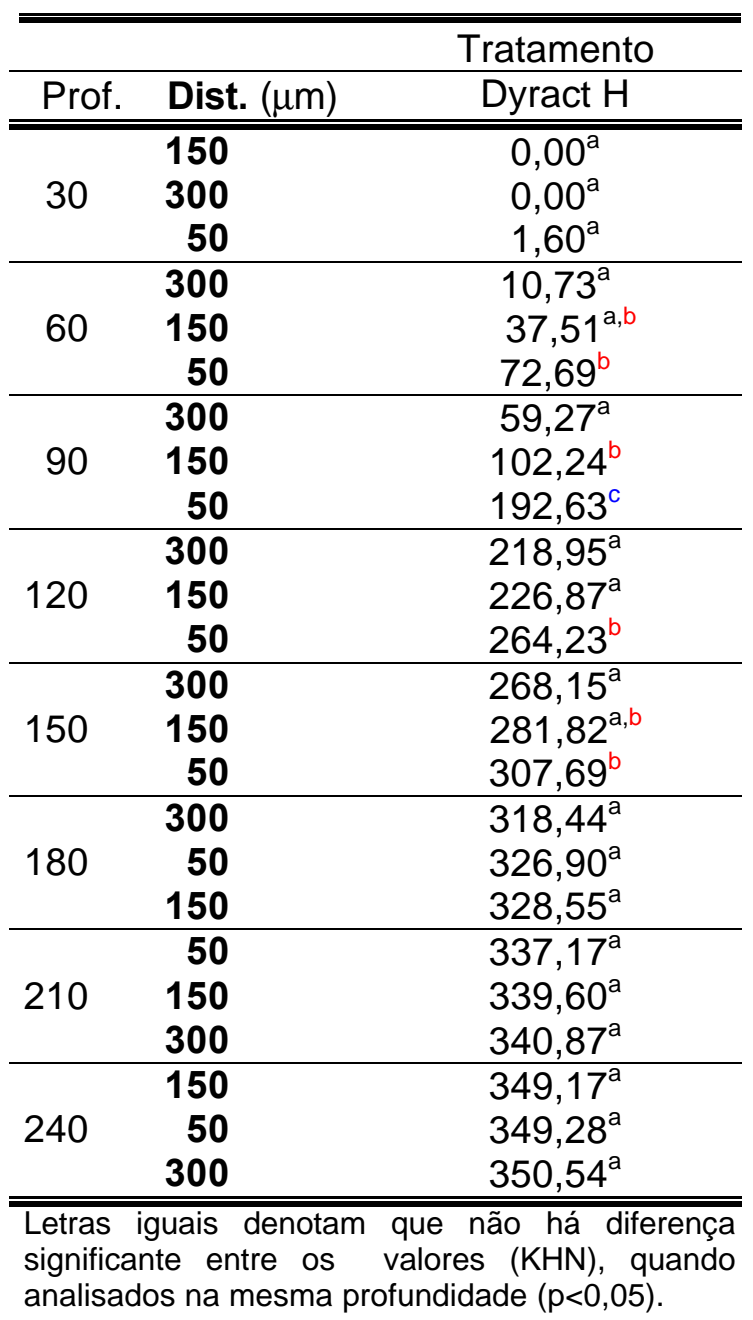

Tabela 13 - Comparação entre as distâncias (50, 150 e $300 \mu \mathrm{m})$ nas diferentes profundidades no tratamento Dyract AP Des

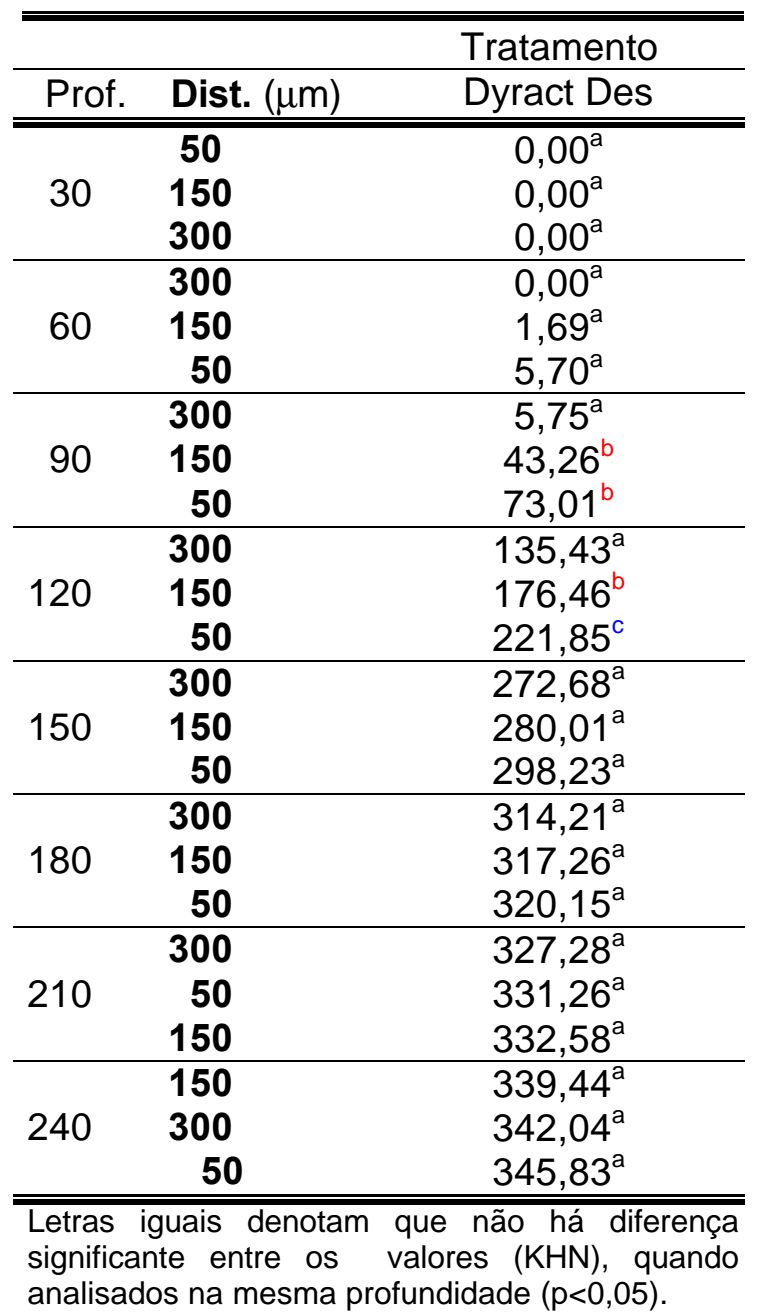


Tabela 14 - Comparação entre as distâncias (50, 150 e $300 \mu \mathrm{m})$ nas diferentes profundidades no tratamento Z-250 H

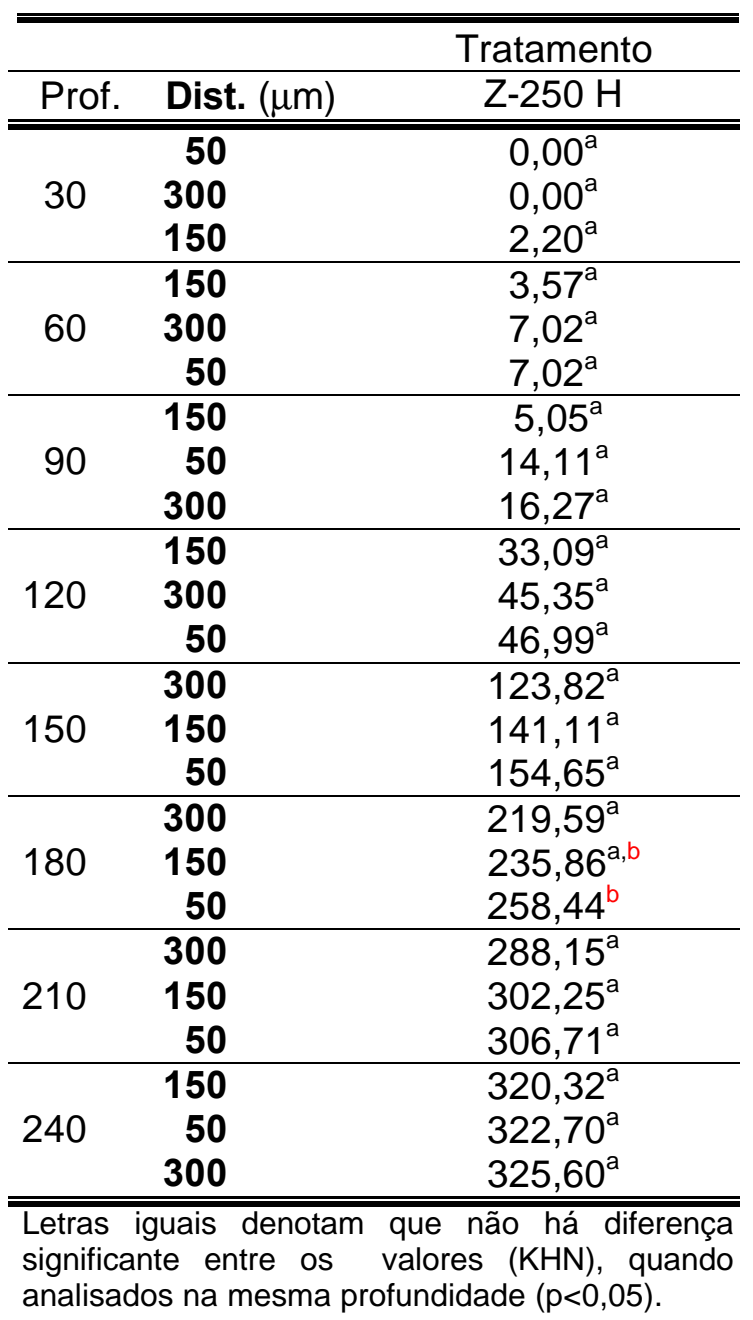

Tabela 15 - Comparação entre as distâncias (50, 150 e $300 \mu \mathrm{m})$ nas diferentes profundidades no tratamento Z-250 Des

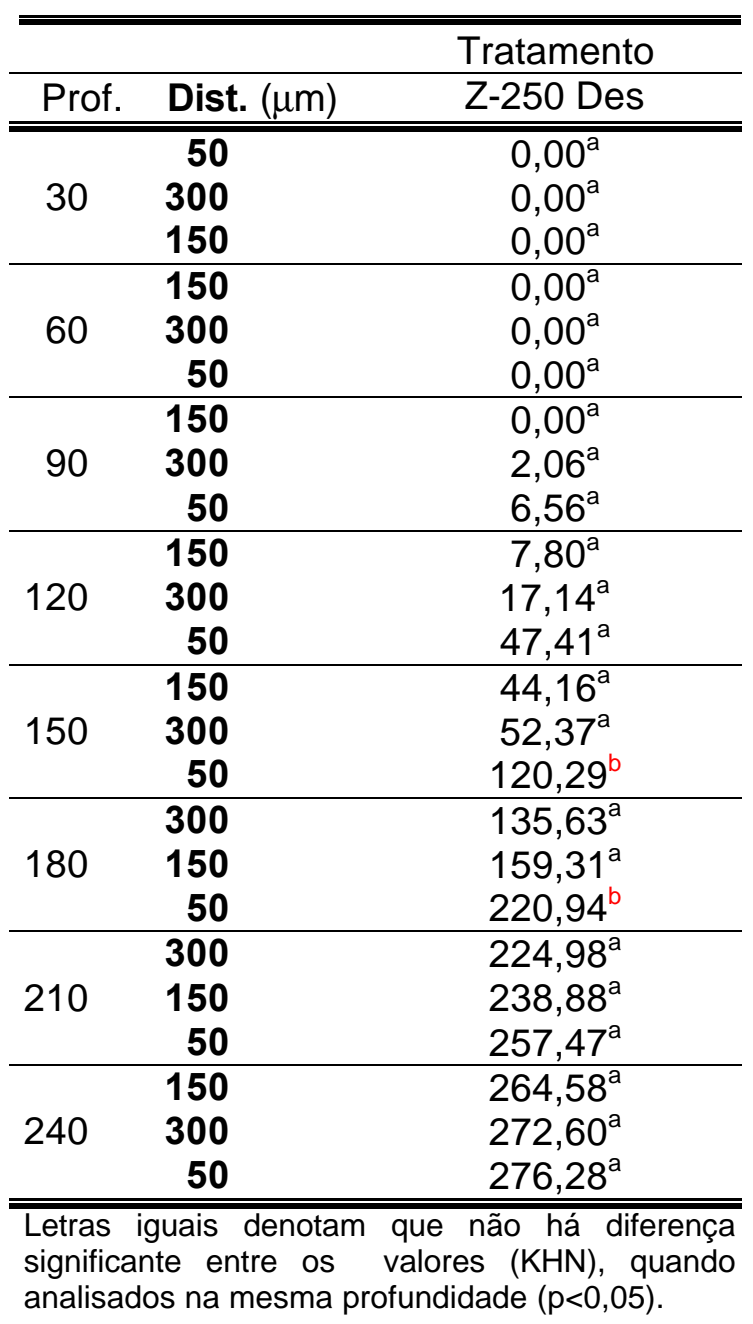

Tabela 16 - Comparação entre as distâncias (50, 150 e $300 \mu \mathrm{m})$ nas diferentes profundidades no tratamento Controle H (S/D)

\begin{tabular}{|c|c|c|}
\hline & & Tratamento \\
\hline Prof. & Dist. $(\mu \mathrm{m})$ & Controle H (S/D) \\
\hline \multirow{3}{*}{30} & 150 & $358,71^{a}$ \\
\hline & 300 & $362,42^{a}$ \\
\hline & 50 & $368,37^{a}$ \\
\hline \multirow{3}{*}{60} & 300 & $372,79^{a}$ \\
\hline & 150 & $373,96^{a}$ \\
\hline & 50 & $391,58^{\mathrm{a}}$ \\
\hline \multirow{3}{*}{90} & 300 & $375,29^{a}$ \\
\hline & 150 & $375,50^{\mathrm{a}}$ \\
\hline & 50 & $379,67^{a}$ \\
\hline \multirow{3}{*}{120} & 50 & $372,21^{a}$ \\
\hline & 300 & $381,54^{a}$ \\
\hline & 150 & $387,58^{a}$ \\
\hline \multirow{3}{*}{150} & 150 & $375,17^{a}$ \\
\hline & 50 & $381,54^{a}$ \\
\hline & 300 & $388,17^{a}$ \\
\hline \multirow{3}{*}{180} & 150 & $375,83^{a}$ \\
\hline & 50 & $377,62^{\mathrm{a}}$ \\
\hline & 300 & $383,42^{a}$ \\
\hline \multirow{3}{*}{210} & 50 & $362,17^{a}$ \\
\hline & 300 & $375,00^{a}$ \\
\hline & 150 & $383,25^{a}$ \\
\hline \multirow{3}{*}{240} & 50 & $376,50^{\mathrm{a}}$ \\
\hline & 150 & $376.83^{a}$ \\
\hline & 300 & $387,46^{a}$ \\
\hline ana & . & 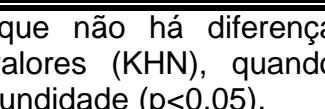 \\
\hline
\end{tabular}


Tabela 17 - Comparação entre as distâncias (50, 150 e $300 \mu \mathrm{m})$ nas diferentes profundidades no tratamento Controle H (C/D)

\begin{tabular}{|c|c|c|}
\hline & & Tratamento \\
\hline Prof. & Dist. $(\mu \mathrm{m})$ & Controle $\mathrm{H}(\mathrm{C} / \mathrm{D})$ \\
\hline & 50 & 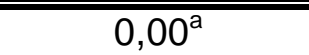 \\
\hline 30 & 150 & $0,00^{a}$ \\
\hline & 300 & $0,00^{\mathrm{a}}$ \\
\hline & 300 & $0,00^{a}$ \\
\hline 60 & 150 & $0,00^{a}$ \\
\hline & 50 & $3,21^{\mathrm{a}}$ \\
\hline & 300 & $8,12^{a}$ \\
\hline 90 & 150 & $34,29^{a}$ \\
\hline & 50 & $43,25^{\mathrm{a}}$ \\
\hline & 300 & $82,29^{a}$ \\
\hline 120 & 150 & $99,29^{a}$ \\
\hline & 50 & $163,46^{b}$ \\
\hline & 300 & $191,71^{\mathrm{a}}$ \\
\hline 150 & 150 & $209,67^{a}$ \\
\hline & 50 & $268,96^{\mathrm{b}}$ \\
\hline & 300 & $260,12^{\mathrm{a}}$ \\
\hline 180 & 150 & $289,58^{a}$ \\
\hline & 300 & $290,17^{\mathrm{a}}$ \\
\hline & 300 & $269,00^{\mathrm{a}}$ \\
\hline 210 & 150 & $292,00^{\mathrm{a}}$ \\
\hline & 50 & $296,33^{a}$ \\
\hline & 300 & $298,37^{a}$ \\
\hline 240 & 50 & $298,71^{\mathrm{a}}$ \\
\hline & 150 & $305,54^{a}$ \\
\hline
\end{tabular}

Tabela 18 - Comparação entre as distâncias (50, 150 e $300 \mu \mathrm{m})$ nas diferentes profundidades no tratamento Controle Des (S/D)

\begin{tabular}{|c|c|c|}
\hline & & Tratamento \\
\hline Prof. & Dist. $(\mu \mathrm{m})$ & Controle Des (S/D) \\
\hline & 50 & $150,08^{\mathrm{a}}$ \\
\hline 30 & 300 & $157,67^{\mathrm{a}}$ \\
\hline & 150 & $171,46^{a}$ \\
\hline & 150 & $296,71^{\mathrm{a}}$ \\
\hline 60 & 300 & $324,83^{a, b}$ \\
\hline & 50 & $332,58^{b}$ \\
\hline & 150 & $361,21^{a}$ \\
\hline 90 & 300 & $361,42^{\mathrm{a}}$ \\
\hline & 50 & $362,62^{a}$ \\
\hline & 50 & $374,25^{a}$ \\
\hline 120 & 300 & $375,92^{\mathrm{a}}$ \\
\hline & 150 & $385,37^{a}$ \\
\hline & 150 & $359,67^{a}$ \\
\hline 150 & 50 & $361,92^{\mathrm{a}}$ \\
\hline & 300 & $364,29^{a}$ \\
\hline & 50 & $363,96^{a}$ \\
\hline 180 & 300 & $373,04^{a}$ \\
\hline & 150 & $376,96^{a}$ \\
\hline & 150 & $369,62^{a}$ \\
\hline 210 & 50 & $369,75^{\mathrm{a}}$ \\
\hline & 300 & $384,58^{a}$ \\
\hline & 50 & $381,87^{a}$ \\
\hline 240 & 150 & $384,46^{a}$ \\
\hline & 300 & $386,62^{a}$ \\
\hline $\begin{array}{l}\text { Letra } \\
\text { signif } \\
\text { analis }\end{array}$ & & $\begin{array}{l}\text { le não há diferença } \\
\text { lores }(K H N) \text {, quandd } \\
\text { hdidade }(\mathrm{D}<0,05) \text {. }\end{array}$ \\
\hline
\end{tabular}


A análise das Tabelas 8 a 18 foi norteada pelas comparações entre as distâncias, considerando-se as suas variações dentro de cada profundidade para cada tratamento.

Para os grupos Ketac Molar H (Tabela 8) e Ketac Molar Des (Tabela 9), microdurezas com diferenças significativas foram encontradas somente dentro da profundidade de $30 \mu \mathrm{m}$ e distância de $50 \mu \mathrm{m}$, onde os valores foram estatisticamente superiores aos das distâncias de 150 e $300 \mu \mathrm{m}$, que não diferiram entre si.

Os tratamentos Vitremer H (Tabela 10) e Vitremer Des (Tabela 11), na profundidade de $30 \mu \mathrm{m}$ e distância de $50 \mu \mathrm{m}$, apresentaram valores de microdureza significantemente maiores que na distância de $300 \mu \mathrm{m}$ e semelhantes aos valores encontrados na distância de $150 \mu \mathrm{m}$. Para o grupo Vitremer H (Tabela 10) na profundidade de $60 \mu \mathrm{m}$, os valores correspondentes à distâncias de 50 e150 $\mu \mathrm{m}$ foram estatisticamente semelhantes entre $\mathrm{si}$, mas significantemente superiores à distância de $300 \mu \mathrm{m}$. O tratamento Vitremer Des (Tabela 11) na profundidade de 150 $\mu \mathrm{m}$ e distância de $50 \mu \mathrm{m}$, mostrou valor significantemente superior em relação à distância de $300 \mu \mathrm{m}$.

Para o tratamento Dyract AP H (Tabela 12), as diferenças com significância estatística foram encontradas dentro da profundidade de $60 \mu \mathrm{m}$, onde nas distâncias de 50 e $150 \mu \mathrm{m}$ a microdureza foi superior, e dentro das profundidades de 90, 120 e $150 \mu \mathrm{m}$, onde os valores correspondentes æ̀ distâncias de $50 \mu \mathrm{m}$ foram superiores aos demais.

Analisando-se o grupo Dyract AP Des (Tabela 13), encontrou-se diferenças estatisticamente significantes dentro da profundidade de $90 \mu \mathrm{m}$, onde a microdureza na distância de $300 \mu \mathrm{m}$ foi inferior à demais e dentro da profundidade de $120 \mu \mathrm{m}$, onde foi observado valor de microdureza mais alto na distância de 50 $\mu \mathrm{m}$, seguido da distância de $150 \mu \mathrm{m}$ e $300 \mu \mathrm{m}$.

A única diferença significante encontrada entre as distâncias no tratamento Z-250 H (Tabela 14) foi na da profundidade de $180 \mu \mathrm{m}$, onde o valor de 
microdureza foi mais alto na distância de $50 \mu \mathrm{m}$ quando comparado ao da distância de $300 \mu \mathrm{m}$.

O tratamento Z-250 Des (Tabela 15) mostrou diferenças com significância estatística dentro das profundidades de 150 e $180 \mu \mathrm{m}$, onde observouse que as microdurezas nas distâncias de $50 \mu \mathrm{m}$ foram superiores as demais.

O grupo Controle H (S/D) (Tabela 16) não apresentou valores de microdureza com diferença estatisticamente significante dentro de todas as profundidades estudadas. Porém, o tratamento Controle H (C/D) (Tabela 17) mostrou diferenças significantes nas profundidades de 120 e $150 \mu \mathrm{m}$, onde os valores encontrados nas distâncias de $50 \mu \mathrm{m}$ (primeira fileira de oito marcas) foram estatisticamente superiores ̊̀ demais distâncias. No tratamento Controle Des (S/D) (Tabela 18), a única diferença significante entre as distâncias foi encontrada na profundidade de $60 \mu \mathrm{m}$, onde o valor correspondente àdistância de $50 \mu \mathrm{m}$ (primeira fileira de oito marcas) foi estatisticamente superior ao da distância de $150 \mu \mathrm{m}$ (segunda fileira de oito marcas). 
6 DISCUSSÃO 


\section{DISCUSSÃO}

Ainda hoje, apesar de todo enfoque educativo/preventivo difundido a respeito da cárie dentária, um sério problema continua preocupando a prática odontológica: o aparecimento de cárie secundária ao redor de restaurações pré existentes ${ }^{25,36,67,68}$. Além disso, é também preocupante, a incidência de cárie na dentição decídua, o que tem contribuído muitas vezes para a perda precoce desses elementos ${ }^{72}$. Portanto, o profissional deve buscar alternativas para a implementação de uma prática odontológica preventiva, capaz de associar materiais e métodos que atendam ذ̀ características individuais do paciente quanto ao risco àdoença cárie ${ }^{72}$.

A ação do flúor, como método preventivo da cárie dentária, potencializando a remineralização e inibindo a desmineralização, é fato evidente, amplamente relatado e documentado na literatura odontológica $29,32,34,36,52,63,65,72,80,90,101,106,107$. Baseando-se nestes achados, a pesquisa de materiais liberadores de flúor tem se desenvolvido muito nos últimos anos, pois a utilização clínica destes materiais é importante para inibir o aparecimento e/ou progressão de cáries secundárias, principalmente em pacientes de alto risco de cárie $^{24,88}$.

É reconhecido, que o flúor considerado mais efetivo para o controle do desenvolvimento do processo da cárie dentária, é aquele presente constantemente na cavidade bucal, com participação direta nos fenômenos de desmineralização e remineralização ${ }^{72}$, não se devendo levar em consideração somente a quantidade de flúor incorporado ao esmalte ${ }^{56,65,101}$. O principal mecanismo de ação do flúor é dinâmico ${ }^{101,34}$, uma vez que a presença deste íon em fase líquida, na saliva ou em fluidos da placa e do esmalte, pode levar a paralisação da lesão ${ }^{101}$. Baseados na ação dinâmica do flúor, muitos pesquizadores têm utilizado metodologias de desenvolvimento de cárie in vitro, para avaliar realmente a efetividade do flúor ${ }^{88}$, em detrimento aos estudos que avaliam liberação ${ }^{2,4,14,15,17,19,20,28,37,38,39,40,41,42,46,47,49,61,66,}$ $70,75,94,98$, incorporação de flúor ${ }^{6,20,37,65,76,84,93,107}$ ou mesmo solubilidade do esmalte $^{78,66}$. 
O presente trabalho também foi realizado in vitro porque é bem estabelecido que este modelo experimental sobre remineralização, desmineralização e reatividade do flúor, proporciona resultados confiáveis ${ }^{108}$.

Com relação à produção de lesões cariosas experimentalmente, a literatura é ampla e variada. As metodologias mais simplificadas se baseiam em soluções tampão acetato ou lactato, contendo ou não íons de cálcio e fosfato 29,30,32,63,74,83,86,109. Vários outros trabalhos têm utilizado gel acidulado $324,27,31,50,53,57,58,90,99,104,110$ como meio de indução de cáries artificiais. Entretanto, estes métodos são meramente estáticos, não reproduzindo as condições encontradas in vivo ${ }^{34,88,101}$.

A produção de lesão incipiente de cárie, ou seja, desmineralização prévia realizada em metade da amostra deste estudo, seguiu a metodologia utilizada por MAIA ${ }^{65}$, mesmo não correspondendo a um modelo dinâmico. Este método foi escolhido porque, de acordo com WHITE ${ }^{105}$, a desmineralização em meios ácidos parcialmente saturados em relação a hidroxiapatita, àsemelhança da metodologia utilizada, resulta na formação de lesões incipientes de cárie, representativas dos estágios preliminares de desmineralização subsuperficial. Os preparos foram realizados no centro dos espécimes e restaurados com os diferentes materiais estéticos, na tentativa de simular o que ocorre nos casos clínicos em que o preparo cavitário é realizado somente onde há cavitação, preservando as áreas de mancha branca ao redor. Isto ocorre com freqüência naqueles casos de cárie precoce na infância, em que a escolha correta do material restaurador ${ }^{24}$, aliada a outras medidas preventivas, é de grande importância para reversão do quadro.

$\mathrm{Na}$ tentativa de melhor reproduzir in vitro as condições encontradas in vivo, o presente trabalho, bem como um grande número de outros anteriores descritos na literatura ${ }^{6,34,37,52,65,80,86,87,88,106,107}$, utilizou um modelo dinâmico de ciclagem de $\mathrm{pH}$ para a produção de lesões de cáries artificiais, simulando as variações na saturação de minerais e as quedas de $\mathrm{pH}$ que ocorrem no meio ambiente bucal ${ }^{101,108}$. Ambos os espécimes, de esmalte hígido e desmineralizado previamente, foram submetidos ao desafio cariogênico. 
O modelo de ciclagem utilizado neste estudo foi o desenvolvido por FEATHERSTONE et al. ${ }^{34}$, em 1986, o qual apresenta correlação com o início e progressão de lesão cariosa in vivo. Segundo o autor, as 6 horas diárias de desafio ácido, através da imersão dos espécimes em solução desmineralizante, simulam o que ocorre in vivo, com aqueles indivíduos que se alimentam com grande freqüência durante o dia. Já as 18 horas, em solução remineralizante, baseiam-se nos períodos de reparo proporcionados pela saliva, in vivo.

Uma dúvida encontrada para utilização desta metodologia foi o fato de que FEATHERSTONE et al. $^{34}$, não relataram em seu trabalho original se as soluções deveriam ou não ser renovadas regularmente, embora muitos autores que fizeram uso deste método trocaram a solução diariamente. Para que este fato ficasse claro, uma comunicação via e-mail foi estabelecida com o autor, o qual respondeu que nas condições do presente estudo, com o volume das soluções e tipo de substrato utilizados, não seria necessária a troca das soluções durante os 14 dias do experimento.

É importante ressaltar, que o desafio cariogênico deste estudo foi mais severo que o proposto por FEATHERSTONE et al. ${ }^{34}$, uma vez que não se utilizou dente humano, mas sim dente bovino como substrato, sendo que metade da amostra já havia sofrido um processo de indução de cárie incipiente. Apesar de apresentar comportamento semelhante ao do esmalte humano em relação à desmineralização, estudos têm demonstrado que o esmalte bovino é mais poroso, resultando em uma taxa de difusão e formação de lesões mais rápidas ${ }^{15,31,74}$. Isto também foi observado no presente estudo, pois um dos grupos (Controle Des C/D) constituído por blocos de esmalte desmineralizado sem preparo cavitário e submetidos ao desafio cariogênico, foi excluído da amostra, pois houve um processo de erosão em toda superfície externa do esmalte, perdendo-se o parâmetro para demarcação das profundidades e impedindo a realização dos ensaios de microdureza. Além disso, perda de estrutura dentária também foi observada em alguns grupos, cujos espécimes foram restaurados com materiais com nenhuma ou pouca quantidade de flúor em sua composição. Entretanto, esta condição pode ser minimizada se modificações forem introduzidas na metodologia proposta 
originalmente, principalmente com relação ao tempo de exposição à solução desmineralizadora, pois sabe-se que a perda mineral é diretamente proporcional ao tempo de desmineralização ${ }^{3,52,110}$. Alterações no pH da solução desmineralizadora, acréscimo de flúor nesta solução e o mínimo desgaste possível do esmalte são medidas que também devem ser levadas em consideração, com o intuito de diminuir o efeito desmineralizador sobre o esmalte bovino.

Entretanto, a escolha pelo dente bovino como substrato, pode ainda ser justificada por vários fatores. Além de serem muito utilizados na literatura para estudos desta natureza $3,29,62,65,74,79,99,102,110$, podem ser conseguidos em grandes quantidades, o que possibilitou a criteriosa seleção dos 144 blocos que fizeram parte da amostra. Embora o esmalte humano possa ser considerado o substrato de escolha, ele apresenta maior variabilidade na composição e na resposta aos testes de desafio cariogênico in vitro ${ }^{13,18,82,102,111}$, devido a fatores genéticos, diferenças quanto a exposição ao flúor ou a desafios cariogênicos anteriores e idade ${ }^{111}$. Outro aspecto importante na escolha dos dentes bovinos para o experimento foi o fato de que os dentes humanos, por apresentarem coroas com dimensões menores e com curvatura mais acentuada ${ }^{13}$ que os dentes bovinos, dificultariam a obtenção de blocos de esmalte apropriados para a aplicação dos testes de microdureza ${ }^{111}$. Esta característica proporciona um menor desgaste da superfície do esmalte para a planificação do bloco, uma vez que menores variações na microdureza são encontradas dentro de uma mesma superfície quando ela é plana ${ }^{13,64}$. Partindo desta premissa, todos os espécimes avaliados neste estudo foram planificados através do desgaste e polimento da superfície do esmalte, antes da aplicação dos ensaios, tanto de microdureza superficial para seleção da amostra, quanto para a análise da microdureza em corte longitudinal.

Os blocos de esmalte utilizados nesta pesquisa foram todos retirados da região central da coroa dos incisivos bovinos, na tentativa de eliminar possíveis variações existentes na dureza das diferentes regiões de um mesmo dente. Entretanto, AMAECHI; HIGHAM; EDGAR ${ }^{3}$, não encontraram diferenças significantes entre a desmineralização ocorrida em diferentes sítios de um mesmo dente bovino, embora variações numericamente maiores tenham ocorrido na região cervical. 
A avaliação da desmineralização do esmalte foi realizada através de testes de microdureza Knoop em secção longitudinal. Embora existam outros métodos para análise da profundidade e extensão de zonas desmineralizadas de lesões de cáries, tais como: microscopia eletrônica de varredura ${ }^{53}$, microscopia de luz polarizada ${ }^{12,24,27,43,45,48,50,53,57,58,62,83,90,91,104,112}$, incorporação de corantes $^{31}$, microrradiografia ${ }^{7,24,35,43,45,52,57,83,86,104,107}$, microscopia confocal a laser ${ }^{35,36}$, os testes de microdureza têm sido empregados em inúmeras pesquisas $5,6,18,30,32,34,37,62,63,65,74,77,80,82,86,87,88,92,99,102,106,107$. Isto porque, além de ser um método mecânico que minimiza a variável humana ${ }^{77}$, é considerado um método sensível e confiável $^{73}$, proporcionado avaliações quantitativas ${ }^{106}$. Deve-se também levar em consideração, que a microdureza é um método rápido e não destrutivo na determinação da profundidade da lesão ${ }^{92}$.

Outra vantagem descrita, é que a ponta piramidal de diamante (penetrador Knoop), produz uma indentação comprida, rasa, estreita, nítida e bem definida $^{77}$ o que reduz fraturas no substrato analisado ${ }^{82}$. Além disso, possibilita 0 estabelecimento de uma relação entre o conteúdo mineral do esmalte e o comprimento da indentação produzida ${ }^{5,30,105}$, demonstrando relação direta entre a perda de cálcio e diminuição da dureza ${ }^{30}$. Com base nesta propriedade, esta metodologia pode ser utilizada para a determinação do potencial cariostático de materiais restauradores.

Embora muitos trabalhos utilizem a microdureza da superfície externa do esmalte s,30,37,62,63,65,74,77,86,92,102,107, $_{\text {SILVERSTONE }}^{90}$ considerou esta medotodologia pouco precisa para o estudo do desenvolvimento de cáries em esmalte, uma vez que elas se formam na subsuperfície, sob uma camada superficial bem mineralizada ${ }^{7}$. Além disso, a microdureza superficial é considerada inadequada para avaliação de lesões cariosas mais profundas que $50 \mu \mathrm{m}^{105}$. Baseando-se nestes aspectos, é relevante que os testes sejam feitos em cortes longitudinais, para que se realize uma avaliação mais detalhada das lesões subsuperficiais ${ }^{82}$. Um aspecto importante, ainda relacionado àmicrodureza longitudinal, e considerado neste estudo, foi a aplicação dos testes nas duas metades do bloco, de cada lado das margens do preparo cavitário. Com isto, tentou-se chegar a valores médios mais 
próximos da realidade do bloco, baseando-se no fato do esmalte não ser um substrato homogêneo ${ }^{64}$, sendo que variações de dureza podem ocorrer em diferentes áreas de um mesmo bloco ${ }^{82}$.

É importante ressaltar, que neste estudo, também foram aplicados testes de microdureza superficial, porém com o objetivo único de padronização da amostra, tanto dos espécimes hígidos quanto dos com lesão de cárie artificial. Este procedimento foi realizado para minimizar as grandes variações existentes entre diferentes dentes e entre o padrão de desmineralização .

Todo o conjunto de características citado anteriormente norteou a escolha, neste estudo, dos testes de microdureza Knoop em secção longitudinal como método de avaliação da desmineralização, o que permitiu a análise quantitativa da perda mineral nas diferentes distâncias da parede cavitária e profundidades em relação àsuperfície externa do esmalte adjacente aos mater iais restauradores estudados.

A análise estatística realizada para comparar as médias de microdureza dos diferentes grupos, mostrou diferenças significativas entre os materiais estudados (Tabelas 2 a 4), entre as diferentes profundidades em relação à superfície externa do esmalte (Tabelas 5 a 7) e entre as três distâncias do preparo cavitário (Tabelas 8 a 18).

Com relação àdistância da parede cavitária, as diferenças encontradas indicam que a desmineralização não ocorreu de forma similar. Para que seja possível a discussão clara dos resultados com relação ̇̀ distâncias faz-se necessário que as mesmas sejam comparadas dentro de cada uma das oito profundidades estudadas. Além disso, é importante ressaltar que a literatura é escassa, quando se trata da discussão da microdureza longitudinal em diferentes distâncias das margens da restauração, sendo que o enfoque maior é dado àação cariostática dos materiais restauradores, independente das diferentes distâncias.

Para o cimento de ionômero de vidro convencional (Ketac Molar), tanto para o grupo com esmalte hígido, quanto para o com esmalte previamente desmineralizado, considerando-se a profundidade de $30 \mu \mathrm{m}$ (região mais próxima à superfície externa do esmalte), pode-se observar que os valores de microdureza 
encontrados na distância de $50 \mu \mathrm{m}$ (região mais próxima ao material restaurador) foram significativamente maiores que nas outras duas distâncias (Tabelas 8 e 9). Analisando-se a mesma profundidade para o Vitremer, aplicado no esmalte hígido (Tabela 10) e desmineralizado (Tabela 11), os maiores valores de microdureza, semelhantes estatisticamente entre si, foram encontrados nas distâncias de 50 e 150 $\mu \mathrm{m}$,

A partir da profundidade de $60 \mu \mathrm{m}$, com exceção feita ao grupo Vitremer $\mathrm{H}$, que manteve as microdurezas maiores à distâncias de $50 \mu \mathrm{m}$ e 150 $\mu \mathrm{m}$, não foram mais observadas diferenças significantes entre a três distâncias para estes dois materiais. Com isso, pode-se sugerir que para o material Ketac Molar, considerando-se a região mais próxima à superfície externa do esmalte (profundidade de $30 \mu \mathrm{m}$ ) e mais exposta ao desafio cariogênico, o maior efeito cariostático deu-se na área mais próxima àmargem da restauração (distância de 50 $\mu \mathrm{m})$. Os resultados encontrados para o Vitremer indicaram que a ação cariostática mais efetiva do material se extendeu um pouco mais, em comparação ao Ketac Molar.

A literatura é conclusiva a respeito da liberação de flúor através dos cimentos de ionômero de vidro 4,11,14,15,17,20,27,28,37,39,41,45,47,48,70,78,98. . Portanto,os achados relacionados àdistância das margens do preparo cavitário podem ser associados ao fato de que a liberação de flúor tenha maior efetividade em áreas mais próximas das margens da restauração ${ }^{20,23,88}$, embora um efeito àdistância do material também possa retardar a progressão da lesão cariosa ${ }^{99}$.

Com relação à resinas compostas: convencional $(Z-250)$ e modificada por poliácidos (Dyract AP), tanto para os corpos de prova com esmalte hígido (Tabelas 14 e 12), quanto para os com esmalte desmineralizado (Tabelas 15 e 13), quando diferenças entre as três distâncias ocorreram, também foram observados valores médios de microdureza mais altos àdistância de $50 \mu \mathrm{m}$. Porém, o que diferiu estes materiais dos ionômeros, foi o aspecto superfície externa do esmalte, pois houve perda de estrutura dentária atingindo diversos graus de profundidade. Devido a este fato, a variável distância das paredes cavitárias praticamente começou a ser avaliada em regiões mais profundas, de acordo com a severidade da erosão 
observada. Para o Dyract AP diferenças foram dectadas nas profundidades entre 90 e $120 \mu \mathrm{m}$ e para a resina composta Z-250, nas profundidades entre 150 e $180 \mu \mathrm{m}$. Considerando ainda, que a resina composta convencional não libera flúor ${ }^{98}$ e a resina composta modificada por poliácidos libera quantidades muito pequenas ${ }^{2,41,98}$, a superioridade da dureza na distância de $50 \mu \mathrm{m}$ para estes materiais, em determinadas profundidades, pode estar relacionada supostamente a outros fatores, como por exemplo, a variações que possam ocorrer dentro de um mesmo bloco ${ }^{64}$ como também foi observado em dois dos grupos não restaurados e, será visto logo adiante. Entretanto, o estudo desta variabilidade não foi objetivo deste trabalho, e esta suposição precisa ser melhor investigada.

Comparando estes dados com os obtidos por SERRA ${ }^{87}$, em 1995, nos quais a autora não observou para nenhum dos materiais estudados, diferenças significantes entre as distâncias por ela analisadas, pode-se a princípio estabelecer que os resultados dos dois trabalhos são conflitantes. Entretanto, deve-se considerar que no presente estudo a primeira distância avaliada foi de $50 \mu \mathrm{m}$ da margem da restauração, enquanto que no estudo conduzido por SERRA ${ }^{87}$, a microdureza começou ser avaliada a partir da distância de $150 \mu \mathrm{m}$ da parede do preparo cavitário, o que vem corroborar com os dados deste trabalho, se forem considerados os valores encontrados a partir de $150 \mu \mathrm{m}$.

A discussão da variável distância da margem do preparo para os grupos que não possuíam restaurações, não é pertinente por motivos óbvios, uma vez que não havendo preparo cavitário, tomou-se como parâmetro para o início das marcações o centro da secção. Entretanto, pode-se salientar que o grupo Controle $\mathrm{H}$ (S/D) (Tabela 16) não apresentou diferenças significantes entre as três seqüências de oito indentações correspondentes à três distâncias dos grupos com restauração. Para os outros dois grupos sem restauração, Controle H (C/D) (Tabela 17) e Controle Des ( $S / D$ ) (Tabela 18), as variações entre as três seqüências que ocorreram de maneira isolada, podem ser provavelmente atribuídas a variações na estrutura interna do próprio esmalte, considerando-se que o esmalte não é um substrato homogêneo, principalmente quando desmineralizado e remineralizado ${ }^{64}$. 
A análise da microdureza Knoop fundamentada nas oito diferentes profundidades com relação àsuperfície externa do esmalte, considerando -se as três distâncias, demonstrou, como era esperado que, de uma maneira geral, os menores valores numéricos de microdureza foram encontrados na profundidade de $30 \mu \mathrm{m}$ (Tabelas 5 a 7), ou seja, na região exposta diretamente ao desafio cariogênico e, à medida que se aprofundava em direção à junção amelo-dentinária houve um aumento da microdureza, tendendo a aproximar-se dos valores de dureza do esmalte hígido, representado aqui pelo grupo Controle $H(S / D)$. Estes dados estão em concordância com os de outros trabalhos descritos na literatura, os quais também analisaram esta variável ${ }^{6,87,88}$. No entanto, as profundidades, nas quais os valores de microdureza tornaram-se próximos aos do esmalte hígido, variaram de acordo com o tratamento estabelecido e com a ação cariostática do material utilizado, porém, isto será discutido a seguir quando for estabelecida a comparação entre os tratamentos.

Com relação aos tratamentos, foi observado que os materiais apresentaram comportamentos distintos principalmente relacionados ao desafio cariogênico.

Comparando-se os grupos que não foram submetidos ao desafio cariogênico - Controle $H(S / D)$ e Controle Des (S/D), notou-se que o grupo formado por espécimes de esmalte hígido apresentou valores de microdureza mais elevados, com significância estatística, nas profundidades de 30 e $60 \mu \mathrm{m}$. Este dado indica que as lesões de cárie incipiente, conseguidas através da metodologia utilizada no presente estudo, atingiram a profundidade de $60 \mu \mathrm{m}$.

A comparação entre o tratamento Controle $H(S / D)$ e os demais grupos restaurados hígidos, demonstra que o tratamento Controle $H(S / D)$ apresentou, nas três distâncias estudadas, valores de microdureza Knoop estatisticamente superiores aos demais grupos nas profundidades de 30 e $60 \mu \mathrm{m}$, indicando portanto que nenhum material restaurador estudado foi capaz de impedir completamente a desmineralização adjacente à restauração, visto que os espécimes restaurados tiveram uma diminuição da dureza em comparação ao esmalte hígido, demonstrando a formação de lesões, mesmo que em diferentes profundidades. 
Estes dados corroboram com os de alguns trabalhos descritos na literatura ${ }^{24,62,91}$, nos quais foi demonstrado que alguns materiais que liberam flúor são capazes de interferir na progressão da lesão, mas não de impedir completamente a iniciação do processo carioso. Em contrapartida, outros estudos indicaram que o cimento de ionômero de vidro foi capaz de impedir completamente a formação da lesão ${ }^{12,53,87}$. Esta discordância pode estar relacionada a prováveis diferenças na composição dos materiais estudados ${ }^{4,14,15,17}$ e variações na metodologia empregada.

Em relação ao grupo Controle $H(C / D)$, os cimentos de ionômero de vidro foram superiores nas três distâncias e em todas as profundidades estudadas, inibindo a progressão da cárie e apresentando uma desmineralização inferior.

Comparando-se a média de microdureza obtida nos blocos que receberam os materiais restauradores, pode-se observar que as melhores propriedades cariostáticas foram observadas para o cimento de ionômero de vidro modificado por poliácidos, Vitremer, quando utilizado em esmalte hígido, uma vez que na região do esmalte mais exposta ao desafio cariogênico (profundidades de 30 e $60 \mu \mathrm{m}$ ), apresentou, com significância estatística, os valores médios de microdureza maiores que todos os outros materiais restauradores, somente não sendo superior ao tratamento Controle $H(S / D)$. Estes achados indicam que para o esmalte hígido o material Vitremer apresentou o melhor efeito cariostático, impedindo a progressão da lesão. O potencial cariostático do Vitremer também tem sido comprovado em diversas avaliações clínicas ${ }^{21,22}$, inclusive por longos períodos, nos quais 0 material mostrou-se durável e confiável $^{21}$, atingindo um índice de sucesso de $93 \%$.

Os grupos Vitremer Des, Ketac Molar H e Des, apresentaram potencial cariostático intermediário com relação ao grupo Vitremer $\mathrm{H}$. Estes dados demonstram também que o cimento de ionômero de vidro convencional Ketac Molar interferiu de maneira semelhante na progressão da lesão, tanto em esmalte hígido, quanto em esmalte desmineralizado. Já o cimento de ionômero de vidro modificado por resina, Vitremer, apresentou desempenho inferior no esmalte desmineralizado em comparação ao esmalte hígido. Estes dados estão de acordo com muitos outros 
trabalhos, nos quais a ação cariostática dos cimentos de ionômeros de vidro, embora em diferentes graus, tem sido demonstrada $29,32,34,36,62,63,65,72,80,90,91,101,106,107$.

KOTSANOS $^{62}$, em 2001, avaliando, in situ, o efeito de materiais restauradores sobre o esmalte sadio, obteve resultados semelhantes ao deste estudo, verificando que o potencial cariostático do Vitremer foi superior ao do Ketac Molar, que por sua vez, foi superior àresina composta modificada por poliácidos $\mathrm{F}$ 2000.

Os materiais Dyract AP e Z-250, não apresentaram nenhuma ação cariostática, tanto em esmalte hígido quanto com lesão incipiente de cárie, demonstrando comportamento semelhante ao grupo Controle $H(C / D)$ nas menores profundidades e para as três distâncias estudadas. Estes materiais não conseguiram impedir a progressão da lesão na região mais próxima àsuperfície externa do esmalte, uma vez que permitiram que o esmalte sofresse um processo de erosão nesta região. Vários outros estudos in vitro ${ }^{24,37,50,57,98}$, também demonstraram a ausência de efeito cariostático de restaurações realizadas com resina composta convencional e modificada por poliácidos. Alguns estudos in vivo, vêm corroborar com o péssimo desempenho de resinas compostas contra o aparecimento de cáries secundárias ${ }^{25,68,103,107}$. Entretanto, outros têm mostrado comportamento clínico aceitável das resinas compostas modificadas por polácidos ${ }^{1,56}$, embora os autores tenham destacado que um conjunto de medidas preventivas tenha sido responsável pelo resultado clínico do caso, salientando-se a importância do seguimento no processo educativo/preventivo da saúde do paciente, associado àindicação do material adequado ̀̀ necessidades do mesmo ${ }^{56}$.

Neste estudo, a resina composta modificada por poliácidos, Dyract AP, mostrou melhor desempenho que a resina composta Z-250, pois apresentou valores de microdureza superiores a partir da profundidade $60 \mu \mathrm{m}$. Esta observação pode estar baseada no fato de que, embora em quantidades mínimas, a resina composta modificada por poliácidos libera de flúor 2,17,41,48.

Com relação ao desempenho dos materiais citados acima, no que diz respeito ao esmalte hígido e com lesão incipiente de cárie, percebeu-se 
comportamento semelhante dos materiais Dyract AP e Z-250 nas duas condições, em muitas das profundidades estudadas e nas três distâncias (50, 150 e $300 \mu \mathrm{m}$ ).

Como já citado anteriormente, as diferenças na ação cariostática encontradas nesta investigação podem estar relacionadas à propriedade dos materiais restauradores de liberar ou não flúor $6,26,28,45,48,57,58,59,66,78,86,93,94$. A liberação de flúor depende de vários fatores como: concentração de flúor no meio ${ }^{47}$, difusão dos íons flúor ${ }^{20,38}$, energia superficial ${ }^{19,66}$ e composição dos materiais ${ }^{14,15,42,46,89}$ relacionada, principalmente, àconcentração e forma química do flúor presente 4 .

Estabelecendo uma comparação entre a liberação de flúor de diferentes materiais restauradores, fica claro que os cimentos de ionômero de vidro liberam maiores quantidades de flúor do que as resinas compostas modificadas por poliácidos 4,14,15,17. Já para a comparação entre os ionômeros convencionais e modificados por resina, a literatura mostra resultados conflitantes. Enquanto alguns trabalhos mostram que a liberação de flúor dos dois materiais é semelhante ${ }^{11,20,41,70,98}$, outros têm indicado liberação superior pelos cimentos de ionômero de vidro modificados por resina ${ }^{10,41,46,47}$.

Outro aspecto relevante para determinar o potencial cariostático de materiais restauradores é a capacidade de determinados materiais readquirirem flúor e liberá-lo posteriormente ${ }^{20}$. Os cimentos de ionômero de vidro convencionais e modificados por resina possuem esta propriedade ${ }^{20,40,46,47,56,98}$ e funcionam como um dispositivo recarregável de liberação lenta de flúor $^{47}$, principalmente em locais de risco de cárie secundária ${ }^{98}$. Por outro lado, também tem-se demonstrado que tanto as resinas compostas convencionais ${ }^{40,98}$, quanto as resinas compostas modificadas por poliácidos ${ }^{41}$ não apresentam este efeito de recarga, o que vem contribuir para o discreto e/ou ausente potencial cariostático destes materiais.

Os resultados deste estudo mostraram que, apesar de nenhum material impedir completamente a instalação da lesão cariosa, os cimentos de ionômero de vidro: convencional (Ketac Molar) e modificado por resina (Vitremer), foram capazes de impedir a progressão da lesão tanto em esmalte hígido quanto em esmalte com lesão incipiente de cárie, demonstrando que possuem ação 
cariostática. Porém, a resina composta convencional (Z-250) e a resina composta modificada por poliácidos (Dyract AP), não apresentaram efeito cariostático. Estes dados podem ser úteis para predizer o desempenho destes materiais em situações de severo desafio cariogênico, pois os mesmos demonstraram diferenças significativas no desenvolvimento de lesões de cárie artificial.

Portanto, pode-se sugerir que em casos de alto risco e/ou atividade de cárie, o material restaurador de escolha deva ser o cimento de ionômero de vidro, tanto o convencional quanto o modificado por resina, uma vez que, devido a sua ação cariostática, são capazes de interferir na progressão e diminuir a severidade de cáries secundárias. 
7 CONCLUSÕES 


\section{CONCLUSÕES}

Através da análise dos resultados obtidos e com base no delineamento experimental utilizado no presente estudo, pode-se concluir que:

Nenhum dos quatro materiais restauradores estudados foi capaz de impedir completamente a instalação da lesão de cárie artifical adjacente ̀̀ restaurações em esmalte dentário bovino;

$>\mathrm{O}$ cimento de ionômero de vidro modificado por resina utilizado em esmalte hígido, apresentou maior efeito cariostático que os outros materiais estudados, interferindo mais efetivamente no desenvolvimento da lesão;

> O cimento de ionômero de vidro convencional aplicado tanto em esmalte hígido, quanto desmineralizado, assim como o cimento de ionômero de vidro modificado por resina, em esmalte desmineralizado, apresentaram potencial cariostástico intermediário;

A resina composta modificada por poliácidos e a resina composta convenciona,I considerando-se tanto o esmalte hígido, quanto o com lesão incipiente de cárie artificial, não apresentaram efeito cariostático, permitindo, inclusive, a erosão da superfície externa do esmalte; 
ANEXOS 
ANEXO 1 - Preparo da solução indutora de lesões de cárie

A) Preparar volume suficiente de solução em função do número de blocos de dente, satisfazendo a proporção de 2,0 mL para cada $1,0 \mathrm{~mm}^{2}$ de área de esmalte.

B) Preparo de solução de ácido láctico $0,05 \mathrm{M} \mathrm{pH} \mathrm{5,0} \mathrm{50 \%} \mathrm{saturada} \mathrm{com} \mathrm{esmalte}$ dentário bovino (E.D.B.):

1 - Transferir $50 \mathrm{~mL}$ de ácido láctico 1,0 M preparado com 1 mês de antecedência, para um béquer contendo aproximadamente $500 \mathrm{~mL}$ de água deionizada. Acertar o $\mathrm{pH}$ com $\mathrm{NaOH}$ e completar o volume para 1 litro em balão volumétrico usando água deionizada. Acrescentar timol $(0,1 \%)$ como conservante.

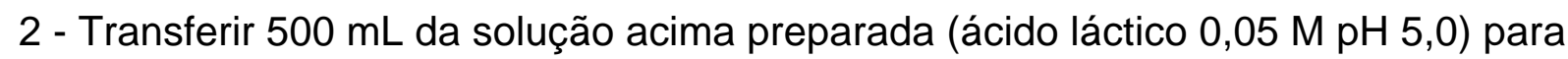
um "erlenmayer" de $1000 \mathrm{~mL}$. Acrescentar 0,25g de E.D.B.(partículas de 0,0740,105 unidades). Colocar $96 \mathrm{~h}$ a $37^{\circ} \mathrm{C}$. Filtrar e acertar o $\mathrm{pH}$ para 5,0.

3 - Misturar a solução acima (ácido láctico 0,05M pH 5,0, 100\% saturada E.D.B.) com os $500 \mathrm{~mL}$ restantes da solução de ácido láctico $0,05 \mathrm{M}, \mathrm{pH} 5,0$, (item 1), obtendo-se uma solução de ácido láctico $50 \%$ saturada. Acrescentar timol $(0,1 \%)$ como conservante.

4 - Deixar os blocos de dente na solução acima por $16 \mathrm{~h}$ a $37^{\circ} \mathrm{C}$, obedecendo a proporção de 2,0 $\mathrm{mL}$ para cada $1,0 \mathrm{~mm}^{2}$ de área de esmalte exposto.

5 - Lavar em água deionizada durante 3 minutos e manter em ambiente úmido. 
ANEXO 2 - Materiais restauradores utilizados no experimento / Técnica restauradora.

\section{1 - Filtek - Z-250}

Fabricante: 3M Dental Products St. Paul, MN, USA

Lote $\mathrm{n}^{\circ} 23050$

Cor: $A_{3,5}$

Técnica restauradora:

- Aplicação do ácido fosfórico em gel Scotchbond a 35\% em esmalte e dentina por 15";

- Lavagem por 10" e remoção do excesso de água com papel absorvente;

- Aplicação do adesivo Single Bond com aplicador descartável Microbrush (Microbrush Corporation, USA). A ponta do aplicador estava saturada de adesivo e duas camadas consecutivas foram aplicadas nas superfícies de esmalte e dentina;

- Secagem suave por 25";

- Fotopolimerização por 10";

- Aplicação da resina em um único incremento com espátula plástica Jon e compressão do material na cavidade com tira de poliéster Odahcam ( Herpo Produtos dentários Ltda, R.J), mantida em posição manualmente;

- Fotopolimerização por 40" sobre tira de matriz de poliéster.

\section{2 - Dyract AP}

Fabricante: Dentsply Indústria e Comércio Ltda, Petrópolis-RJ

Lote $\mathrm{n}^{\circ} 0008000770$

Cor: $\mathrm{B}_{3}$

Técnica restauradora:

- Aplicação de duas camadas do Prime \& Bond 2.1, utilizando aplicador descartável Microbrush, em esmalte e dentina por 30"; 
- Remoção de eventuais excessos do material através de leve jato de ar por 3 a 5";

- Fotopolimerização por 10";

- Aplicação de nova camada do Prime \& Bond 2.1 e, imediatamente, remoção do excesso com leves jatos de ar;

- Fotopolimerização por 10";

- Inserção na cavidade em porção única com o compule que contém o material adaptado à pistola que acompanha o Kit, e compressão do material na cavidade com tira de poliéster Odahcam, mantida em posição manualmente;

- Fotopolimerização por 40" sobre a tira de poliéster;

\section{3 - Vitremer}

Fabricante: 3M Dental Products St. Paul, MN, USA

Lotes nos 19990816 (pó), 19990421 (líquido), 19990630 (primer)

Cor: $\mathrm{A}_{3}$

Técnica restauradora:

- Aplicação do primer nas superfícies de esmalte e dentina por 30", com aplicador descartável Microbrush;

- Secagem por 15" com seringa de ar e fotopolimerização por 20";

- Manipulação do pó e líquido: agitação do frasco de pó antes da utilização. A colher-medida, depois de estar cheia de pó foi nivelada para remoção do excesso. A gota do líquido foi dispensada com 0 frasco na vertical. A proporção pó / líquido utilizada foi de 1:1. A espatulação do material foi realizada em bloco de papel;

- Inserção do material na cavidade em porção única, com o auxílio de uma seringa Centrix ( Centrix Incorp., Stratford. C.T., USA), de tal maneira que a ponta da seringa ficasse imersa no material para evitar a incorporação de bolhas de ar; 
- Compressão do material na cavidade com tira de poliéster Odahcam, mantida em posição manualmente e fotopolimerização por 40" sobre a tira de poliéster;

\section{4 - Ketac Molar}

Fabricante: ESPE Dental AG- Germany

Lote $\mathrm{n}^{\circ}$ FW0062314

Cor: $\mathrm{A}_{3}$

Técnica restauradora:

- Limpeza da cavidade com bolinha de algodão embebida no próprio líquido do material;

- Remoção do excesso com bolinha de algodão e jatos de ar;

- Manipulação do pó e líquido: agitação do frasco de pó antes da utilização. A colher-medida, depois de estar cheia de pó foi nivelada para remoção do excesso. A gota do líquido foi dispensada com o frasco na vertical. A proporção pó / líquido utilizada foi de 1:1. A espatulação do material foi realizada em bloco de papel, sendo que o pó foi incorporado ao líquido em 2 porções e espatulado até a obtenção de uma mistura homogênea, respeitando o tempo de mistura de 45";

- Inserção do material na cavidade em porção única, com o auxílio de uma seringa Centrix ( Centrix Incorp., Stratford. C.T., USA), de tal maneira que a ponta da seringa ficasse imersa no material para evitar a incorporação de bolhas de ar;

- Compressão manual do material na cavidade com tira de poliéster Odahcam por 10" e em seguida proteção da restauração com base para unhas Colorama (CEIL - ComL. Exp. Ind. Ltda - SP / Brasil).

OBS: O aparelho de luz fotopolimerizadora utilizado para todos os materiais fotopolimerizáveis foi o Optilux (Demetron Research Corporation). 
ANEXO 3 - Médias de microdureza Knoop e respectivos desvios-padrão (d.p.) para os diferentes tratamentos, profundidades em relação àsuperfície externa do esmalte e àdistância de $50 \mu \mathrm{m}$ da parede cavitária.

\begin{tabular}{|c|c|c|c|c|c|c|c|c|}
\hline \multicolumn{9}{|c|}{ Profundidade ( $\mu \mathrm{m})$} \\
\hline Tratamento & \begin{tabular}{|c|}
30 \\
médias (d.p.)
\end{tabular} & $\begin{array}{c}60 \\
\text { médias (d.p.) }\end{array}$ & $\begin{array}{c}90 \\
\text { médias (d.p.) }\end{array}$ & \begin{tabular}{|c|}
120 \\
médias (d.p.)
\end{tabular} & \begin{tabular}{|c}
150 \\
médias (d.p.)
\end{tabular} & $\begin{array}{c}180 \\
\text { médias (d.p.) }\end{array}$ & $\begin{array}{c}\mathbf{2 1 0} \\
\text { médias (d.p.) }\end{array}$ & \begin{tabular}{|c|}
240 \\
médias (d.p.)
\end{tabular} \\
\hline Controle $\mathrm{H}(\mathrm{S} / \mathrm{D})$ & $368,37(48,98)$ & $391,58(31,08)$ & $379,67(40,40)$ & $372,21(40,11)$ & $381,54(38,76)$ & $377,62(39,46)$ & $362,17(40,72)$ & $376,50(41,28)$ \\
\hline Controle Des (S/D) & $150,08(47,75)$ & $296,70(66,25)$ & $362,62(39,87)$ & $374,25(36,98)$ & $361,91(32,16)$ & $363,96(39,29)$ & $368,75(36,87)$ & $387,87(28,94)$ \\
\hline Vitremer $\mathrm{H}$ & $277,85(28,17)$ & $328,99(14,16)$ & $327,49(25,78)$ & $336,09(27,84)$ & $335,36(22,81)$ & $337,44(20,11)$ & $338,48(20,75)$ & $344,39(18,44)$ \\
\hline Vitremer Des & $223,73(13,28)$ & $257,70(24,07)$ & $273,51(27,66)$ & $289,84(23,17)$ & $318,35(21,44)$ & $315,25(18,09)$ & $324,31(14,16)$ & $341,28(11,60)$ \\
\hline Ketac Molar H & $244,85(25,73)$ & $261,35(40,89)$ & $275,75(32,58)$ & $285,62(35,52)$ & $302,34(25,47)$ & $320,24(14,64)$ & $333,12(18,33)$ & $342,54(18,40)$ \\
\hline Ketac Molar Des & $207,77(10,73)$ & $272,75(28,23)$ & $296,14(27,54)$ & $300,67(24,18)$ & $308,58(29,56)$ & $320,11(16,14)$ & $324,35(14,96)$ & $336,66(13,85)$ \\
\hline Dyract AP H & $1,60(5,56)$ & $72,69(59,08)$ & $192,63(63,15)$ & $264,22(49,32)$ & $307,69(27,60)$ & $326,90(16,21)$ & $337,17(12,59)$ & $349,25(13,22)$ \\
\hline Dyract AP Des & $0,00(0,00)$ & $5,69(19,73)$ & $73,01(55,70)$ & $221,84(56,78)$ & $298,23(33,48)$ & $320,15(14,20)$ & $331,26(11,47)$ & $345,83(5,57)$ \\
\hline Controle $\mathrm{H}(\mathrm{C} / \mathrm{D})$ & $0,00(0,00)$ & $3,21(11,11)$ & $43,25(63,78)$ & $163,46(89,24)$ & $268,96(67,32)$ & $290,17(32,13)$ & $296,33(31,44)$ & $298,71(31,74)$ \\
\hline Z-250 H & $0,00(0,00)$ & $7,02(24,33)$ & $14,11(27,83)$ & $46,99(46,37)$ & $154,65(69,56)$ & $258,44(60,35)$ & $306,71(26,71)$ & $322,70(20,93)$ \\
\hline Z-250 Des & $0,00(0,00)$ & $0,00(0,00)$ & $6,56(15,33)$ & $47,41(41,07)$ & $120,29(62,68)$ & $220,94(45,74)$ & $257,47(42,89)$ & $276,28(33,02)$ \\
\hline
\end{tabular}


ANEXO 4 - Médias de microdureza Knoop e respectivos desvios-padrão (d.p.) para os diferentes tratamentos, profundidades em relação àsuperfície externa do esmalte e àdistância de $150 \mu \mathrm{m}$ da parede cavitária.

\begin{tabular}{|c|c|c|c|c|c|c|c|c|}
\hline \multicolumn{9}{|c|}{ Profundidade ( $\mu \mathrm{m})$} \\
\hline Tratamento & \begin{tabular}{|c|}
30 \\
médias (d.p.)
\end{tabular} & $\begin{array}{c}60 \\
\text { médias (d.p.) }\end{array}$ & $\begin{array}{c}90 \\
\text { médias (d.p.) }\end{array}$ & \begin{tabular}{|c|}
120 \\
médias (d.p.)
\end{tabular} & \begin{tabular}{|c}
150 \\
médias (d.p.)
\end{tabular} & $\begin{array}{c}180 \\
\text { médias (d.p.) }\end{array}$ & $\begin{array}{c}\mathbf{2 1 0} \\
\text { médias (d.p.) }\end{array}$ & \begin{tabular}{|c|}
240 \\
médias (d.p.)
\end{tabular} \\
\hline Controle $\mathrm{H}(\mathrm{S} / \mathrm{D})$ & $358,71(46,43)$ & $373,96(41,27)$ & $375,50(41,60)$ & $387,58(34,49)$ & $375,17(33,15)$ & $376,96(39,69)$ & $383,25(34,90)$ & $376,83(36,39)$ \\
\hline Controle Des (S/D) & $171,46(25,95)$ & $332,58(47,08)$ & $361,21(50,42)$ & $385,37(29,03)$ & $359,67(38,61)$ & $375,83(34,14)$ & $369,62(41,07)$ & $384,46(26,89)$ \\
\hline Vitremer $\mathrm{H}$ & $267,21(25,61)$ & $329,39(22,87)$ & $335,74(21,23)$ & $334,75(24,56)$ & $338,92(20,25)$ & $336,43(21,08)$ & $332,58(28,85)$ & $345,08(23,65)$ \\
\hline Vitremer Des & $214,74(15,94)$ & $254,97(21,03)$ & $279,93(19,28)$ & $304,77(24,24)$ & $309,88(14,57)$ & $320,67(15,58)$ & $324,53(9,75)$ & $338,31(11,29)$ \\
\hline Ketac Molar H & $220,04(33,22)$ & $252,95(36,48)$ & $283,40(24,79)$ & $290,12(36,07)$ & $299,59(27,72)$ & $323,19(19,02)$ & $329,27(15,79)$ & $338,23(14,28)$ \\
\hline Ketac Molar Des & $198,78(12,35)$ & $263,42(31,29)$ & $293,10(36,73)$ & $298,25(53,51)$ & $308,69(26,59)$ & $317,85(16,89)$ & $326,99(12,46)$ & $335,88(15,89)$ \\
\hline Dyract AP H & $0,00(0,00)$ & $37,51(47,84)$ & $102,24(69,28)$ & $226,87(37,34)$ & $281,82(36,94)$ & $328,55(22,32)$ & $339,60(11,46)$ & $349,17(9,28)$ \\
\hline Dyract AP Des & $0,00(0,00)$ & $1,69(5,84)$ & $43,26(48,04)$ & $176,46(75,40)$ & $280,00(37,65)$ & $317,26(14,24)$ & $332,58(12,42)$ & $339,43(7,99)$ \\
\hline Controle $\mathrm{H}(\mathrm{C} / \mathrm{D})$ & $0,00(0,00)$ & $0,00(0,00)$ & $34,29(60,80)$ & $99,29(103,07)$ & $209,67(116,81)$ & $289,58(61,48)$ & $292,50(31,11)$ & $305,54(34,03)$ \\
\hline Z-250 H & $2,20(7,62)$ & $3,57(12,38)$ & $5,05(17,49)$ & $33,09(41,67)$ & $141,11(84,99)$ & $235,86(67,99)$ & $302,25(36,73)$ & $320,32(24,50)$ \\
\hline Z-250 Des & $0,00(0,00)$ & $0,00(0,00)$ & $0,00(0,00)$ & $7,79(19,92)$ & $44,16(34,74)$ & $159,31(37,53)$ & $238,88(39,97)$ & $264,58(35,96)$ \\
\hline
\end{tabular}


ANEXO 5 - Médias de microdureza Knoop e respectivos desvios-padrão (d.p.) para os diferentes tratamentos, profundidades em relação àsuperfície externa do esmalte e àdistância de $300 \mu \mathrm{m}$ da parede cavitária.

\begin{tabular}{|c|c|c|c|c|c|c|c|c|}
\hline \multicolumn{9}{|c|}{ Profundidade ( $\mu \mathrm{m})$} \\
\hline Tratamento & \begin{tabular}{|c|}
30 \\
médias (d.p.)
\end{tabular} & $\begin{array}{c}60 \\
\text { médias (d.p.) }\end{array}$ & $\begin{array}{c}90 \\
\text { médias (d.p.) }\end{array}$ & \begin{tabular}{|c|}
120 \\
médias (d.p.)
\end{tabular} & \begin{tabular}{|c|}
150 \\
médias (d.p.)
\end{tabular} & $\begin{array}{c}180 \\
\text { médias (d.p.) }\end{array}$ & $\begin{array}{c}\mathbf{2 1 0} \\
\text { médias (d.p.) }\end{array}$ & \begin{tabular}{|c|}
240 \\
médias (d.p.)
\end{tabular} \\
\hline Controle $\mathrm{H}(\mathrm{S} / \mathrm{D})$ & $362,41(40,84)$ & $372,79(40,29)$ & $375,29(43,34)$ & $381,54(32,64)$ & $388,17(34,90)$ & $383,42(33,07)$ & $375,00(38,44)$ & $387,46(24,24)$ \\
\hline Controle Des (S/D) & $157,67(26,88)$ & $324,83(68,36)$ & $361,42(44,50)$ & $375,92(32,14)$ & $364,28(36,84)$ & $373,04(40,20)$ & $384,58(23,04)$ & $386,62(24,04)$ \\
\hline Vitremer $\mathrm{H}$ & $250,20(28,74)$ & $308,00(25,16)$ & $325,12(25,42)$ & $336,99(29,23)$ & $334,68(21,66)$ & $335,13(22,79)$ & $339,27(20,61)$ & $350,30(22,26)$ \\
\hline Vitremer Des & $199,64(24,33)$ & $247,48(23,67)$ & $274,04(23,54)$ & $283,39(31,48)$ & $298,88(26,75)$ & $316,64(16,13)$ & $320,58(12,60)$ & $337,67(14,08)$ \\
\hline Ketac Molar H & $213,60(33,50)$ & $256,32(41,44)$ & $277,85(47,53)$ & $285,53(41,63)$ & $303,18(28,24)$ & $327,03(21,61)$ & $333,44(17,29)$ & $344,01(18,01)$ \\
\hline Ketac Molar Des & $191,24(12,70)$ & $260,60(29,94)$ & $289,37(33,26)$ & $302,84(33,20)$ & $307,37(35,14)$ & $323,49(14,71)$ & $322,08(16,09)$ & $335,90(15,55)$ \\
\hline Dyract AP H & $0,00(0,00)$ & $10,73(19,90)$ & $59,26(41,84)$ & $218,95(49,69)$ & $268,15(38,45)$ & $318,44(27,70)$ & $340,87(17,93)$ & $350,54(14,24)$ \\
\hline Dyract AP Des & $0,00(0,00)$ & $0,00(0,00)$ & $5,75(19,92)$ & $135,53(86,24)$ & $272,68(38,10)$ & $314,21(15,11)$ & $327,28(15,57)$ & $342,04(4,65)$ \\
\hline Controle $\mathrm{H}(\mathrm{C} / \mathrm{D})$ & $0,00(0,00)$ & $0,00(0,00)$ & $8,12(20,20)$ & $82,29(81,70)$ & $191,70(116,33)$ & $269,12(107,95)$ & $269,00(72,84)$ & $298,37(54,13)$ \\
\hline Z-250 H & $0,00(0,00)$ & $7,02(16,47)$ & $16,27(24,72)$ & $45,35(44,43)$ & $123,82(78,85)$ & $219,59(69,97)$ & $288,15(49,12)$ & $325,60(15,41)$ \\
\hline Z-250 Des & $0,00(0,00)$ & $0,00(0,00)$ & $2,06(7,14)$ & $17,14(27,74)$ & $52,37(52,96)$ & $135,63(77,24)$ & $224,99(40,64)$ & $272,56(27,49)$ \\
\hline
\end{tabular}


REFERÊECIAS BIBLIOGRÁFICAS 


\section{REFERÊNCIAS BIBLIOGRÁFICAS*}

1 ABDALLA, A.I.; ALHADAINY, H.A; GARCIA-GODOY, F. Clinical evaluation of glass ionomers and compomers in class $\mathrm{V}$ carious lesions. Amer. J. Dent., v.10, n.1, p.15-20, Feb. 1997

2 AGUILAR-GÁLVEZ, D.P.C. Avaliação in vitro da liberação de flúor e atividade antimicrobiana dos compômeros restauradores. Bauru, 1998 139p. Dissertação (Mestrado) - Faculdade de Odontologia de Bauru, Universidade de São Paulo.

3 AMAECHI, B.T.; HIGHAM, S.M.; EDGAR, W.M. Factors affecting the development of carious lesions in bovine teeth in vitro. Arch. oral Biol., v.43, n.8, p.619-28, Aug. 1998.

4 ARENDS, J; RUBEN, J. Fluoride release a composite resin. Quintessence Int., v.19, n.7, p.513-4, July 1988.

5 ARENDS, J.; SCHUTHOF, J.; JONGEBLOED, W.G. Microhardness indentations on artificial white spot lesions. Caries Res, v.13, n.5, p.209-7, Sept./ Oct. 1979.

6 BENELLI, E.M. el at. In situ anticariogenic potential of glass ionomr cement. Caries Res., v.27, n.4, p.280-4, July/Aug. 1993.

7 BERGMAN; G.; LIND, P.O. A quantitative microradiografic study of incipient enamel caries. J. dent. Res., v.45, n.5, p.1477-84, May 1966.

8 BRANDAU, H.E.; ZIEMIECK, T.L.; CHARBENEAU, G.T. Restorations of cervical contours on nonprepared teeth using glass ionomer cement: a 4 1/2 year report. J. Amer. dent. Ass., v.108, n.5, p.782-3, May 1984.

9 BRANTLEY, C.F. et al. Does the cycle of restoration lead to larger restorations? J.Amer. dent. Ass., v.126, n. 10, p.1407-13, Oct. 1995.

10 BROOKS, E.S. et al. Manipulation effects on fluoride release from conventional and light-cured glass-ionomers. J.dent. Res., v.73, p.133, Mar. 1994 / Abstract 255/ Special issue.

\footnotetext{
* Normas recomendadas para uso no âmbito da Universidade de São Paulo, com base no documento "Referências bibliográficas: exemplos", emanado do Conselho Supervisor do Sistema Integrado de Bibliotecas da USP, em reunião de 20 de setembro de 1990.
} 
11 BURKE, F.J.T. et al. Materials for restoration of primary teeth: 2.Glass ionomer derivatives and compomers. Dent. Update, v.29, n.1, p.10-7, Jan./Feb. 2002

12 BYNUM, M.; DONLY, K.J. Caries inhibition of two light cured glass ionomer restorative materials. J. dent. Res., v.73, p.417, Mar. 1994/ Abstract 2522/ Special issue.

13 CALDWELL, R.C. et al. Microhardness studies of intact surface enamel. J. dent. Res., v.36, n.5, p.732-8, May 1957.

$14 \mathrm{CAO}, \mathrm{D} . \mathrm{S}$. et al. Fluoride release from glass ionomers, glass ionomers/resins, \& composites. J. dent. Res., v.73, p.184, Mar. 1994. /Abstract 657/ Special issue

15 CARVALHO, A.S; CURY, J.A. Liberação de flúor de materiais restauradores. Rev. Odont. USP, v.12, n.4, p.367-373, out./dez. 1998

16 CARVALHO, R.M. Ionômero de vidro. Maxi-Odonto: Dentística, v.1, Fasc.5, set/out. 1995.

17 COSTA, B. Avaliação "in vitro" da atividade antimicrobiana e liberação de flúor de cimentos de ionômero de vidro restauradores químicos e fotoativados. Bauru, 1995 132p. Dissertação (Mestrado) - Faculdade de Odontologia de Bauru, Universidade de São Paulo.

18 CRAIG, R.G.; PEYTON, F.A. The microhardness of enamel and dentin. J. dent. Res., v. 37, n.4, p.661-8, Apr. 1958

19 CRANFIELD, M.; KUHN, A.T.; WINTER, G.B. Factors relating to the rate of fluoride-ion release from glass-ionomer cement. J. Dent., v.10, n.4, p.333-41, Dec. 1982.

20 CREANOR, S.L. et al. Fluoride uptake and release characteristics of glass ionomer cements. Caries Res., v.28, n.5, p.322-8, Sep./Oct. 1994.

21 CROLL, T.P.; HELPIN, M.L.; DONLY, K.J. Vitremer restorative cement for children: three clinicians' observations in three pediatric dental practices. $\mathbf{J}$. Dent. Child., v.67, n.6, p.391-8, Nov./Dec. 2000.

22 CROLL, T.P. et al. Clinical performance of resin-modified glass ionomer cement restorations in primary teeth. J. Amer. dent. Ass., v.132, n.8, p. 1110-16, Aug. 2001.

23 DAMEN, J.J.M: et al. In vitro fluoride uptake by intra-orally aged and contaminated glass ionomer cement. Caries Res., v.33, n.1, p.88-90, Jan./Feb. 1999. 
24 DERAND, T.; JOHANSSON, B. Experimental secondary caries around restorations in roots. Caries Res., v.18, n.6, p.548-54, Nov./Dec. 1984.

25 vanDIJKEN, J.W.V. A clinical evaluation of anterior conventional, microfiller, and hybrid composite resin fillings. Acta odont. Scand., v.44, n.6, p.357-67, Nov./Dec. 1986.

26 vanDIJKEN, J.W.V.; KIERI, C.; CARLÉN, M. Longevity of extensive class II opensandwich restorations with a resin-modified glass-ionomer cement. J. dent. Res., v.78, n.7, p. 1319-25, July 1999.

27 DIONYSOPOULOS, $\mathrm{P}$. et al. Artificial caries formation around fluoride-releasing restorations in roots. J. oral Rehab., v.25, n.11, p.814-20, Nov. 1998.

28 DONLY, K.J. Enamel and dentin demineralization inhibition of fluoride-releasing materials. Am. J. Dent, v.7, n.5, p.275-8, Oct. 1994.

29 FEAGIN, F. et al. Study of effect of calcium, phosphate, fluoride an hydrogen ion concentrations on the remineralization of partially demineralized human and bovine enamel surfaces. Arch. oral Biol., v.16, n.5, p.535-48, May. 1971.

30 FEAGIN, F.; KOULOURIDES, T.; PIGMAN, W. The characterization of enamel surface demineralization, remineralization, and associated hardness changes in human and bovine material. Arch. oral Biol., v.14, n.12, p.1407-17, Dec. 1969.

31 FEATHERSTONE, J.D.B.; MELLBERG, J.R. Relative rates of progress of artificial carious lesions in bovine, ovine and human enamel. Caries Res., v.15, n.1, p.109-14, Jan./Feb. 1981.

32 FEATHERSTONE, J.B.D. et al. Remineralization of artificial caries-like lesions in vivo by a self-administered mouthrinse or paste. Caries Res., v.16, n.3, p. 235-42, May/June 1982.

33 FEATHERSTONE, J.B.D. et al. Comparison of artificial caries-like lesions by quantitative microradiography and microhardness profiles. Caries Res., v.17, n.5, p.385-91, Sept./Oct. 1983.

34 FEATHERSTONE, J.D.B. et al. Enhancement of remineralization in vitro and in vivo. In: $\mathrm{LEACH}$, S.A. Factors relating to demineralization and remineralization of the teeth. Oxford, IRL, 1986., p.23-34.

35 FONTANA, $M$. et al. Measurement of enamel demineralization using microradiography and confocal microscopy. Caries Res., v.30, n.4, p.317325, July/Aug. 1996. 
36 FONTANA, M. et al. Inhibition of secondary lesion progression using fluoride varnish. Caries Res., v.36, n.2, p.129-35, Mar./Apr. 2002.

37 FORSS, H.; SEPPÄ, L. Prevention of enamel demineralilization adjacent to glass ionomer filling materials. Scand. J. dent. Res., v.98, n.2, p.173-8, Apr. 1990.

38 FORSTEN, L. Fluoride release from a glass ionomer cement. Scand. J. dent. Res., v.85, n.6, p.503-4, Dec. 1977.

39 FORSTEN, L. Short and long-term fluoride release from glass ionomers and other fluoride containing filling materials in vitro. Scand. J. dent. Res., V.98, n.2, p.179-85, Apr. 1990

40 FORSTEN, L. Fluoride release and uptake by glass ionomer cement. Scand. J. dent. Res., v.99, n.3, p.241-5, June 1991.

41 FORSTEN, L. Resin-modified glass ionomer cements: fluoride release and uptake. Acta odont. Scand., v.53, n.4, p.222-5, Jul./Ago. 1995.

42 GROBLER, S.R.; ROSSOUW, R.J.; van WIK KOTZE, T.J. A comparison of fluoride release from various dental materials. J. Dent., v.26, n.3, p. 259-65, Mar. 1998.

43 HALS, E. Histology of natural secondary caries associated with silicate cement restoration in human teeth. Arch.oral Biol., v.20, n.4, p.291-6, Apr. 1975.

44 HALS, E.; MÖRCH, T.; SAND, H.S. Effect of lactate buffers on dental enamel in vitro - as observed in polarizing microscope. Acta Odont. Scand., v.13, n.1, p.83-122, Feb. 1955

45 HALS, E.; NORDEVAL, I.T. Histopathology of experimental in vivo caries around silicate fillings. Acta Odont. Scand., v.31, n.6, p.357-67, Dec. 1973.

46 HATIBOVIC-KOFMAN, G.; KOCH, G.; EKSTRAND, J. Glass ionomer materials as a rechargeable fluoride -release system. Int. J. Paed. Dent., v.7, n.2, p.65-73, June 1997

47 HATIBOVIC-KOFMAN, G.; KOCH, G.; Fluoride release from glass inomer cement in vivo and in vitro. Swed. Dent. J., v.15, n.6, p.253-8, Dec. 1991.

48 HATIBOVIC-KOFMAN, S.; SULJAK, J.P.; KOCH, G.; Remineralization of natural carious lesions with a glass ionomer cement. Swed. Dent. J., v.21, n.1-2, p.11-17 1997. 
49 HATTAB, F.N. et al. An in vivo study on the release of fluoride from glassionomer cement. Quintessence Int., v.22, n.3, p. 221-4, Mar. 1991

50 HATTAB, F.N.; MOK, N.Y.C.; AGNEW, E.C. Artificially formed carieslike lesions around restorative materials. J. Amer. dent. Ass., v.118, n.2, p.193-202, Feb. 1989.

51 HEAD, J. A study of saliva and its action on tooth enamel reference to its hardening and softening. J. Amer. Med. Ass., v.59, p. 2118-22, Dec. 1912.

52 HERKSTRÖTER, F.M.; WITJES, M.; ARENDS, J. Demineralization of human dentine compared with enamel in a pH-cycling apparatus with a constant composition during de-and remineralization periods. Caries Res., v.25, n.5, p.317-322, Sept./Oct. 1991

53 HICKS, M.J.; FLAITZ, C.M.; SILVERSTONE, L.M. Secondary caries formation in vitro around glass ionomer restorations. Quintessence Int., v.17, n.9, p.52732, Sept. 1986.

54 HODGE, H.C. Hardness tests on teeth. J. dent. Res., v.15, n.5, p.271-79, May 1936.

55 HODGE, H.C.; MCKAY, H. The microhardness of teeth. J.Amer. dent. Ass., v.20, n.2, p.227-33, Feb. 1933.

56 HOLANDA, S.C.; BEZERRA, A.C.B.; TOLEDO, O.A. Reabilitação de dentes decíduos anteriores e posteriores em paciente com cárie na primeira infância usando material liberador do flúor. J. Br. Odontop. Odont. Bebê, v.3, n.16, p.441-6, nov./dez. 2000.

57 KAMBHU, P.P.; ETTINGER, R.L.; WEFEL, J.S. An in vitro evaluation of artificial caries-like lesions on restored overdenture abutments. J. dent. Res., v.67, n.3, p.582-4, Mar. 1988.

58 KIDD, E.A.M. Cavity sealing ability of composite and glass ionomer cement restorations. Brit. dent. J., v.144, n.5, p.139-42, Mar. 1978.

59 KILPATRICK, N.M. Glass ionomer cements: their application in children. Part I. Dental Update, v.23, n.6, p.236-8, July/Aug. 1996.

60 KNOOP, F.; PETERS, G.C.; EMERSON, W.B. A sensitive pyramidal diamond tool for indentation measurements. J. Res. Nat. Bur. Stds., v.23, p.39-61, 1939 apud NEWBRUN, E.; PIGMAN, W. The hardness of enamel and dentine. Aust. dent. J., v.5, n.4, p.210-7, Aug. 1960. 
$61 \mathrm{KOCH}, \mathrm{G}$; HATIBOVIC-KOFMAN, S. Glass ionomer cements as a fluoride release system in vivo. Swed. Dent. J., v.14, n.6, p. 267-73, Dec. 1990.

62 KOTSANOS, N. An intraoral study os caries induced on enamel in contact with fluoride-releasing restorative materials. Caries Res., v.35, n.3, p.200-4, May/June 2001.

63 KOULOURIDES, T.; FEAGIN,F.; PIGMAN, W. Remineralization of dental enamel by saliva in vitro. Ann. N. Y. Acad. Sci., v.131, n.2, p. 751-7, Sept 1965.

64 KOULOURIDES, T.; HOUSCH, T. Hardness testing and microradiography of enamel in relation to intraoral de- and remineralization. In: LEACH, S.A.; EDGAR, W.M., eds. Demineralization and remineralization of the teeth. Oxford, IRL Press, 1983.

65 MAIA, L.C. Estudo in vitro do efeito de dentifrício e/ou verniz fluoretado na remineralização e incorporação de fluoreto no esmalte dental. Rio de Janeiro, 1997 124p. Dissertação (Mestrado) - Faculdade de Odontologia, Universidade Federal do Rio de Janeiro.

66 MALDONADO, A.; SWARTZ, M.L.; PHILLIPS, R.W. An in vitro study of certain properties of a glass ionomer cement. J. Amer. dent. Ass., v.96, n.5, p.78591, May 1978.

67 MJÖR, I.A. Placement and replacement of restorations. Oper. Dent., v.1, n.6, p.49-54 1981.

68 MJÖR, I.A. Frequency of secondary caries at various anatomical locations. Oper.Dent., v.10,n.3,p.88-92, May/June 1985.

69 MOUNT, G.J. Letter to the editor. Quintessence Int., v.25, n.4, p.225-6, Apr. 1994

70 NAGAMINE, M. et al. Effect of light-cured glass ionomers on secondary caries in vitro. J.dent. Res., v.73, p.133, Mar. 1994 / Abstract 256/ Special issue.

71 NAVARRO, M.F.L.; PALMA, R.G.; DEL'HOYO, R.B. O que é preciso saber a respeito de ionômero de vidro? In: Congresso Paulista de Odontologia. São Paulo, 1994 p.61-74.

72 NAVARRO, M.F.L; PASCOTTO, R.C. Cimentos de ionômero de vidro. São Paulo, Artes Médicas, 1998.

73 NEWBRUN, E.; PIGMAN, W. The hardness of enamel and dentine. Aust. dent. J., v.5, n.4,p.210-7, Aug. 1960. 
74 NEWBRUN, E.; TIMBERLAKE, P.; PIGMAN, W. Charges in microhardness of enamel following treatment with lactate buffer. J. dent. Res., v.38, n.2, p.293300, Feb. 1959.

75 NORMAN, R.D.; PHILLIPS, R.W.; SWARTZ, M.L. Fluoride uptake by enamel from certain dental materials. J. dent. Res., v.39, n.1, p.11-6, Jan. 1960.

76 NORMAN, R.D.; PHILLIPS, R.W.; SWARTZ, M.L. Aditional studies on fluoride uptake by enamel from certain dental materials. J. dent. Res., v.40, n.3, p.529-37, Mar. 1961.

77 PHILLIPS, R.W.; SWARTZ, M.L. Effect of fluorides on hardness of tooth enamel. J. Amer. dent. Ass., v.37, n.1, p.1-13, July 1948.

78 PHILLIPS, R.W.; SWARTZ, M.L. Effect of certain restoratives materials on solubility of enamel. J. Amer. dent. Ass., v.54, n.5, p.623-36, May 1957.

79 PICKERILL, H.P. The prevention of dental caries and oral sepsis. London, Baillière, Tindal \& Cox, 1912 apud NEWBRUN, E.; PIGMAN, W. The hardness of enamel and dentine. Aust. dent. J., v.5, n.4, p.210-7, Aug. 1960.

80 PIMENTA, L.A.F. et al. Inhibition of demineralization in vitro around amalgam restorations. Quintessence Int., v.29, n.6, p. 363-7, June 1998.

81 PROELL, F.W.; SCHUBERT, K. Die ritzhärte des schmelzes. Ztsch. F. Stomatol., v.26, p. 1047-63, 1928 apud NEWBRUN, E.; PIGMAN, W. The hardness of enamel and dentine. Aust. dent. J., v.5, n.4, p.210-7, Aug. 1960.

82 PURDELL-LEWIS, D.J.; GROENEVELD, A.; ARENDS, J. Hardness tests on sound enamel and artificially demineralized white spot lesion. Caries Res., v.10, n.3, p. 201-15, May/June 1976.

83 PURTON, D.G.; RODDA, J.C. Artificial caries around restorations in roots. J. dent. Res., v.67, n.5, p.817-21, May 1988.

84 RETIEF, D.H. et al. Enamel and cementum fluoride uptake from a glass ionomer cement. Caries Res., v.18, n.3, p.250-7, May/June 1984

85 SCHEMEHORN, B.R.; WOOD, G.D.; ROBERTS, J.A. Comparison of surface hardness and TMR results from an in vitro remineralization model. Caries Res., v.30, n.4, p.275, July/Aug. 1996 Abstract 26.

86 SEGURA, A.; DONLY, K.J.; STRATMANN, R.G. Enamel remineralization on teeth adjacent to class II glass ionomer restorations. Amer. J. Dent., v.10, n.5, p. 247-50, Oct. 1997. 
87 SERRA, M.C. Estudo in vitro do desenvolvimento de cárie em esmalte adjacente a materiais restauradores contendo flúor. Bauru, 1995 65p. Tese (Doutorado) - Faculdade de Odontologia de Bauru, Universidade de São Paulo.

88 SERRA, M.C.; CURY, J.A. The in vitro effect of glass-ionomer cement restoration on enamel subjected to a demineralization and remineralization model. Quintessence Int., v.23, n.2, p.143-7, Feb. 1992.

89 SIDHU, S.K.; WATSON, T.F. Resin-modified glass ionomer materials. Amer. J. Dent., v.8, n.1, p.59-67, Feb. 1995.

90 SILVERSTONE, L.M. The effect of fluoride in the remineralization of enamel caries and caries-like lesions in vitro. J. Publ. HIth. Dent., v.42, n.1, p.42-53, Winter 1982.

91 SMALES, R.J.; GAO, W. In vitro caries inhibition at the enamel margins of glass ionomer restoratives developed for ART approach. J. Dent., v. 28, n.4, p.24956, May 2000.

92 SOUDER, W.; SCHOONOVER, I.C. Abrasion and solution of teeth : a sensitive, visual method for detecting these injuries. J. Amer. dent. Ass., v.30, p.172534, Nov. 1943.

93 SWARTZ, M.L. et al. Fluoride distribution in teeth using a silicate model. J. dent. Res., v.59, n.10, p.1596-603, Oct. 1980.

94 SWARTZ, M.L.; PHILLIPS, R.W.; CLARK, H.E. Long-term F release from glass ionomer cements. J. dent. Res., v.63, n.2, p.158-60, Feb. 1984.

95 SWEENEY, W.T. The Knoop indentation hardness instrument as a tool in dental research. J. dent. Res., v.21, n.3, p.303, Mar. 1942.

96 SWIFT JR, E.J. Effects of glass ionomer on recurrent caries. Oper.Dent., v.14, n.1, p.40-3, Winter 1989.

97 SWIFT JR, E.J. Fluoride release from two composite resins. Quintessence Int. , v. 20, n.12, p.895-7, Dec. 1989.

98 TAKAHASHI, K.; EMILSON, C.G.; BIRKHED, D. Fluoride release in vitro from various glass ionomer cements and resin composites after exposure to $\mathrm{NaF}$ solutions. Dent. Mat., v.9, n.11, p.350-4, Nov. 1993.

99 TANTBIROJN, D.; DOUGLAS, W.H.; VERSLUIS, A. Inhibitive effect of a resinmodified glass ionomer cement on remote enamel artificial caries. Caries Res., v.31, n.4, p.275-80, July/Aug. 1997. 
100 TAY, W.M. An update on glass-ionomer cements. Dental Update, v.22, n.7, p.283-6, Sep. 1995.

101 TEN CATE, J.M. In vitro studies on the effects of fluoride on de-remineralization. J. dent. Res., v.69, p.614-19, Feb. 1990. Special issue.

102 TENUTA, L.M.A. Efeito da placa bacteriana de 4, 7 e 10 dias na desmineralização do esmalte dental in situ e possível relação com fatores salivares e microbiológicos. Bauru, 2001 118p. Dissertação (Mestrado) - Faculdade de Odontologia de Bauru, Universidade de São Paulo.

103 TYAS, M.J. Cariostatic effect of glass ionomer cement: a five year cinical study. Aust. Dent. J., v.36, n.3, p.236-9, June 1991.

104 WESENBERG, G.; HALS, E. The structure of experimental in vitro lesions around glass ionomer cement restorations in human teeth. J. oral. Rehab., v.7, n.2, p.175-84, Feb. 1980.

105 WHITE, D.J. Reactivity of fluoride dentifrices with artificial caries. I. Effects on early lesions: F uptake, surface hardening and remineralization. Caries Res., v.21, n.2, p.126-40, Mar./Apr. 1987.

106 WHITE, D.J.; FEATHERSTONE, J.D.B. A longitudinal microhardness analysis of fluoride dentifrice effects on lesion progression in vitro. Caries Res., v.21, n.6, p.502-12, Nov./Dec. 1987.

107 WHITE, D.J. Reactivity of fluoride dentifrices with artificial caries. II. Effects on subsurface lesions: $F$ uptake, $F$ distribution surface hardening and remineralization. Caries Res., v.21, n.1, p.27-36, Jan./Feb. 1988.

108 WHITE, D.J. The application of in vitro models to research on demineralization and remineralization of the teeth. Adv. dent. Res., v.9, n.3, p.175-193, Nov.1995.

109 WILSON, A.D.; KENT, B.E. A new translucent cement for dentistry. The glass ionomer cement. Brit.dent.J., v.132, n.4, p.133-5, Feb. 1972.

110 ZERO, D.T. et al. Comparison of the iodide permeability test, surface microhardness test e mineral dissolution of bovine following acid challenge. Caries Res., v.24, n.3, p.181-8, May/June 1990.

111 ZERO, D.T. In situ caries models. Adv. dent. Res., v.9, n.3, p.214-30, Nov.1995. 
112 ZIMMERMAN, B.F.; RAWLS,H.R.; QUERENS, A.E. Prevention of in vitro secondary caries with an experimental fluoride-exchanging restorative resin. J. dent. Res., v.63, n.5, p. 689-92, May 1984. 


\section{ABSTRACT}

Considering that caries around restorations is a serious problem in Dentistry and that some restorative materials with fluoride may be important to inhibit these lesions, this research had the aim to evaluate, in vitro, the cariostatic action of some aesthetic restorative materials. Standardized cavities were prepared in the center of both healthy blocks of bovine enamel or with incipient artifical caries lesions. The specimens were restored with: a conventional glass ionomer cement (Molar Ketac); a resin-modified glass ionomer cement (Vitremer); a polyacid-modified composite resin (Dyract AP) and a conventional composite resin (Z-250). Besides the restored specimens, other four corresponding controls the controls groups were also evaluated. All the groups, with exception of two of the controls, were submitted to a demineralization and remineralization cycling model for 14 days, simulating a situation of severe cariogenic challenge. After this procedure, the blocks were seccioned longitudinally through the restorations. Then mineral loss was evaluated using the Knoop microhardness profiles in longitudinal section, in three different distances of the cavities and in eight distinct depths in relation to the external surface of the enamel. The statistic analysis of the results showed significant differences $(p<0,05)$ among the groups, although none of the studied materials were able to completely inhibt the installation of the lesions. Vitremer demonstrated the best cariostatic action in healthy bovine enamel. Ketac Molar, in healthy or demineralized enamel, as well as the Vitremer in demineralized enamel, had presented intermediate cariostatic potential. Z-250 and Dyract AP had not demonstrated cariostatic effect. The data suggest that, the glass ionomer cements demonstred better cariostatic action than the other restorative materials. 